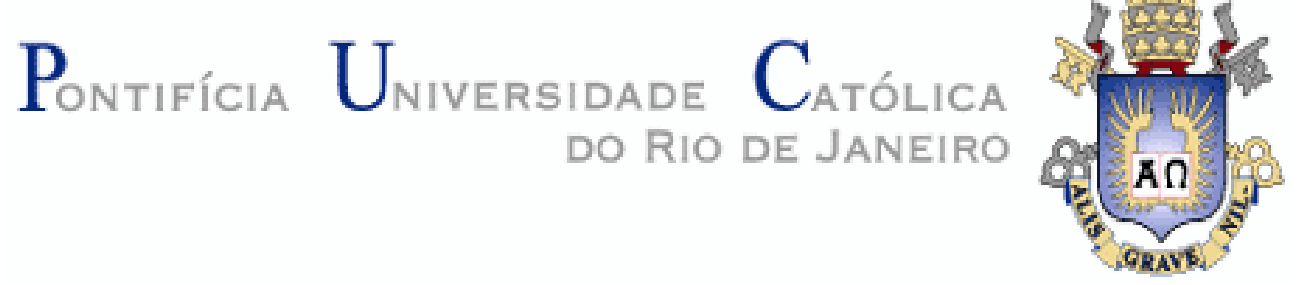

Isabel Paranhos Monteiro

\title{
VESTINDO CINEMA Construindo Ilusão Uma visão do cinema através da janela do figurino
}

Dissertação apresentada como requisito parcial para obtenção do grau de Mestre pelo Programa de Pósgraduação em Design do Departamento de Artes \& Design da PUC-Rio

Orientadora: Prof ${ }^{a}$. Denise Berruezo Portinari Coorientador: Prof. Miguel de Serpa Pereira 


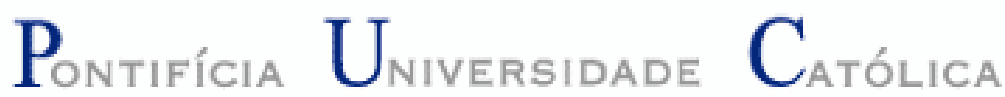 \\ DO RIO DE JANEIRO

Isabel Paranhos Monteiro

\section{VESTINDO CINEMA Construindo Ilusão Uma visão do cinema através da janela do figurino}

Dissertação apresentada como requisito parcial para obtenção do grau de Mestre pelo Programa de Pósgraduação em Design do Departamento de Artes \& Design do Centro de Teologia e Ciências Humanas da PUC-Rio. Aprovada pela Comissão Examinadora abaixo assinada.

\author{
Profa. Denise Berruezo Portinari \\ Orientadora \\ Departamento de Artes \& Design - PUC-Rio
}

Prof. Miguel de Serpa Pereira

Coorientador

Departamento de Comunicação Social - PUC-Rio

Profa. Tatiana de Oliveira Siciliano Departamento de Comunicação Social - PUC-Rio

Profa. Lidia Kosovski Departamento de Artes Cênicas - UNIRIO

Profa . Denise Berruezo Portinari Coordenadora Setorial do Centro de Teologia e Ciências Humanas - PUC-Rio

Rio de Janeiro, 8 de abril 2016 
Todos os direitos reservados. É proibida a reprodução total ou parcial do trabalho sem autorização da universidade, da autora e da orientadora.

\section{Isabel Paranhos Monteiro}

Graduou-se em Educação Artística nas Faculdades Integradas Bennett. Trabalha em direção de arte e figurino de cinema desde 1983. Inaugurou a cadeira de direção de arte para filme de ficção na PUC-Rio em 2010.

Ficha Catalográfica

Monteiro, Isabel Paranhos

Vestindo cinema : construindo ilusão : uma visão do cinema através da janela do figurino / Isabel Paranhos Monteiro ; orientadora: Denise Berruezo Portinari ; co-orientador: Miguel de Serpa Pereira. - 2016.

$135 \mathrm{f}$. : il. ; $30 \mathrm{~cm}$

Dissertação (mestrado)-Pontifícia Universidade Católica do Rio de Janeiro, Departamento de Artes e Design, 2016.

Inclui bibliografia

1. Artes e design - Teses. 2. Cinema. 3. Figurino.

4. Imaginário. 5. Corpo histórico. 6. Processo de Criação

I. Portinari, Denise Berruezo. II. Pereira, Miguel de Serpa.

III. Pontifícia Universidade Católica do Rio de Janeiro. Departamento de Artes e Design. IV. Título. 


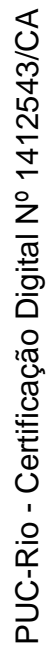

Para Marialva e Ronald 


\section{Agradecimentos}

Aos meus orientadores Denise Portinari e Miguel Pereira, Aos meus professores e colegas. 


\section{Resumo}

Monteiro, Isabel Paranhos, Portinari, Denise Berruezo; Pereira, Miguel de Serpa. VESTINDO CINEMA Construindo Ilusão Uma visão do cinema através da janela do figurino. Rio de Janeiro, 2016. 135p. Dissertação de Mestrado - Departamento de Artes \& Design, Pontifícia Universidade Católica do Rio de Janeiro

O ano de 1990 foi o marco de uma grande crise na indústria cinematográfica do Brasil. Motivos políticos e econômicos, somados a uma crise generalizada no país, assinaram o obituário do cinema nacional. Quatro anos depois, com o auxílio de leis e incentivos fiscais, deu-se a chamada "retomada do cinema brasileiro". Grandes bilheterias, indicações ao Oscar e uma renovação no desenho e na forma de produção apareceriam para abrir o caminho de uma nova cinematografia brasileira. $\mathrm{O}$ figurino de filmes de época produzidos nesta fase, com seus projetos de pesquisa e a construção de seus corpos históricos, são o objeto dessa dissertação.

\section{Palavras-chave}

Cinema; figurino; imaginário; corpo histórico; processo de criação. 


\section{Abstract}

Monteiro, Isabel Paranhos, Portinari, Denise Berruezo; Pereira, Miguel de Serpa. DRESSING CINEMA building Illusion the cinema point of view through the costume window. Rio de Janeiro, 2016. 135p. MSc. Dissertation - Departamento de Artes \& Design, Pontifícia Universidade Católica do Rio de Janeiro

The year 1990 was the mark of a great crisis in the film industry of Brazil. For political and economic reasons, added to a general crisis in the country, signed the obituary of national cinema. Four years later, with the help of laws and tax exemptions it happenned the so called "retomada do cinema brasileiro (the return of the brazilian cinema)".

\section{Keywords}

Cinema; costumes; imaginary; historical body; creation process. 


\section{Sumário}

1. Introdução 15

2. Vestindo o Cinema Brasileiro $\quad 21$

2.1. INCE - Instituto Nacional do Cinema Educativo 23

2.2. Os Grandes Estúdios $\quad 25$

2.2.1. Cinédia 26

2.2.2. Atlântida (Atlantida Empresa Cinematográfica do Brasil S.A) 27

2.2.3. Vera Cruz (Companhia Cinematográfica Vera Cruz) 30

2.3. Cinema Novo 33

2.4. Cinema da Retomada 42

3. Vestindo o Cinema 51

3.1. O Quatrilho 53

3.1.1. O primeiro passo do processo: o roteiro 54

3.1.2. A locação $\quad 57$

3.1.3. A pesquisa de campo 57

3.1.4. A pesquisa de materiais $\quad 59$

3.1.5. A pesquisa de hábitos e costumes 59

3.1.6. A fabricação de figurinos 62

3.1.7. O tempo e o espaço históricos 63

3.1.8. O traje histórico - A chegada dos italianos 66

3.1.9. Os trajes femininos gaúchos 66

3.1.10. O traje colono 67

3.2. Carlota Joaquina, princesa do Brazi 72

3.2.1. Referências $\quad 75$

3.2.2. Cores 82

3.2.3. Personagens 88

3.2.4. Produção de baixo custo 95

3.3. Guerra de Canudos 98

3.3.1. O figurino 100

$\begin{array}{ll}\text { 3.3.2. Pesquisa histórica } & 100\end{array}$ 
3.3.4. Logística 105

3.3.5. Materiais e envelhecimento 107

3.3.6. Referências e bagagem 109

3.3.7. Figuração 111

3.3.8. Tecnologia 112

4. Desenhando cinema, projetando figurino: Design

e cinema na construção de uma identidade visual 113

4.1. O molde do design 114

4.2. A Costura do cinema 121

4.3. Alinhavando a trama: Cinema e design 123

5. Considerações finais 126

6. Ficha técnica dos filmes analisados

7. Referências bibliográficas 


\section{Lista de figuras}

Figura 1 - Cena do filme $O$ Guarani

Figura 2 e 3 - Cenas do filme $O$ Apólogo dentro da caixa

de costura (personagens agulha e linha) 25

Figuras 4 e 5 - Cena do filme Alô,alô, Carnaval 27

Figura 6 - Cartaz do filme Bonequinha de Seda 27

Figura 7 - Cena do filme Bonequinha de Seda 27

Figura 8 e 9 - Nem Sansão Nem Dalila 28

Figura 10 - Matar ou Correr $\quad 29$

Figura 11 - Cena do filme Assim era Atlântida

(1975, Carlos Manga) 29

Figura 12 - Cena do filme Sinhá Moça 31

Figura 13 - Cartaz de Revista com Eliane Lage (Sinhá Moça) 32

Figura 14 - Cena do filme Deus e o Diabo na Terra do Sol 35

Figura 15 Cenas do filme Os Herdeiros 36

Figuras 16 e 17- Cenas do filme Capitu 36

Figura 18 - Cenas do filme Pindorama 37

Figuras 19 e 20 - Quadros de Theodore de Bry 39

Figura 21 e 22 - Cenas do filme Como era Gostoso meu Francês 39

Figura 23 e 24 - Cenas do filme Os Inconfidentes 39

Figura 25 - Cena do filme São Bernardo 41

Figura 26 - Cenas do filme Xica da Silva 42

Figura 27 - Cena do filme Baile Perfumado 45

Figura 28 - Cena do filme Lisbela e o Prisioneiro 48

Figura 29 - Cena do filme Cazuza $\quad 48$

Figura 30 - Cena do filme Olga $\quad 48$

Figura 31 - Cena do filme Faroeste Caboclo 50

Figura 32 - Cena do filme Meu nome Não é Johnny 50

Figura 33 - Desenho e foto do figurino 56

Figura 34 - Foto de cena $\quad 57$

Figura 35 - Catalogação de materiais $\quad 58$

Figura 36 - Cena do filme $\quad 60$ 
Figura 37 - Dálmetes

Figura 38 - Objetos e artesanato 61

Figura 39 - Foto de época $\quad 61$

Figura 40 - Cena do filme $\quad 62$

Figura 41 - Desenho de modelagem 63

Figura 42 - Desenho de modelagem 63

Figura 43 - Cenas do filme 63

Figura 44 - Cena do filme $\quad 67$

Figura 45 - Cena do filme 68

Figura 46 - Cena do filme $\quad 68$

Figura 47 - Cena do filme 68

Figura 48 - Bata $\quad 69$

Figura 49 - Cena do filme $\quad 69$

Figura 50 - Cena do filme $\quad 71$

Figura 51 - Cena do filme A Ronda da Noite 78

Figura 52 - Quadro de Rembrandt $\quad 78$

Figura 53 - Cena do filme $O$ cozinheiro, o ladrão a mulher $\begin{array}{ll}\text { e o amante } & 79\end{array}$

Figura 54 Cena do filme $O$ cozinheiro, o ladrão a mulher e o amante $\quad 79$

Figura 55 - Cena do filme $\mathrm{O}$ cozinheiro, o ladrão a mulher e o amante $\quad 79$

Figura 56 - Cena do filme Carlota Joaquina $\quad 80$

Figura 57 - Cena do filme Carlota Joaquina $\quad 80$

Figura 58 - Cena do filme Tempestade de Jarman $\quad 81$

Figura 59 - Cena do filme Tempestade de Jarman 81

Figura 60 - Cena do filme Tempestade de Peter Greenaway 82

Figura 61- Cena do filme Tempestade de Peter Greenaway 82

Figura 62 - Cena do filme Carlota 83

Figura 63 - Cena do filme Carlota 83

Figura 64 - Cena do filme Carlota 83

Figura 65 - Cena do filme Carlota $\quad 84$

Figura 66 - Cena do filme Carlota $\quad 84$

Figura 67 - Cena do filme Carlota $\quad 84$ 
Figura 68 - Cena do filme Carlota

Figura 69 - Cena do filme Carlota

Figura 70 - Cena do filme Carlota

Figura 71 - Cena do filme Carlota

Figura 72 - Cena do filme Carlota

Figura 73 - Cena do filme Carlota 86

Figura 74 - Cena do filme Carlota

Figura 75 - Pintura Timbalada

Figura 76 - Cena do filme

Figura 77- Cena do filme Carlota

Figuras 78 e 79 - À esquerda cena do filme com a infanta Carlota e seus vermelhos.Na imagem à direita, um vestido copiado do original apresentado em uma exposição no Rio de Janeiro* com curadoria da mesma Emilia Duncan

Figura 80 - Cena do filme Carlota 89

Figura 81- Corpete Westwood 90

Figura 82 - Cena do filme Carlota 90

Figura 83 - Cena do filme Carlota

Figura 84 Cena do filme Carlota

Figura 85 - Cena do filme Carlota

Figura 86 - Cena do filme 92

Figura 87- Cena do filme Carlota 92

Figura 88 - Tapeçaria Gobelin 92

Figura 89 - Tecido chita 92

Figura 90 - Cena do filme Carlota 93

Figura 91 - Cena do filme Carlota 94

Figura 92 - Cena do filme Carlota 94

Figura 93 - Cena do filme Carlota 94

Figura 94 - Cena do filme Carlota 95

Figura 95 - Cena do filme Carlota 95

Figura 96 - Cena do filme Carlota 96

Figura 97 - Cena do filme Carlota 96

Figura 98 - Desfile Jun Nakao 97

Figura 99 - Foto Flavio de Barros 
Figura 100 - Foto Flavio de Barros

Figura 101 - Cenas do filme Canudos

Figura 102 - Indigueira (Indigofera Suffruticosa Mill)

104

Figura 103 - Cena do filme Canudos

104

Figura 104 - Cena do filme Canudos com referência

105

Figura 105 - Ateliê no Rio de Janeiro

106

Figura 106 - Ateliê no Rio de Janeiro

Figura 107 - Tecidos acervo Filipecki 108

Figura 108 - Tecidos acervo Filipecki 108

Figura 109 - Quadro Bandeira de Mello

Figura 110 - Quadro Portinari com tecidos de referência 110

Figura 111- Uniformes de campos de concentração

Figura 112 - Matéria

Figura 113 - Presidiários de Saginaw 
O cinema, ao mesmo tempo que é mágico, é estético e, ao mesmo tempo que é estético é afetivo. Cada um destes termos pressupõe o outro. Metamorfose mecânica do espetáculo de sombra e luz surge o cinema no decurso de um processo milenário de interiorização da velha magia das origens. O seu nascimento, numa nova labareda mágica, processa-se com os sobressaltos de um vulcanismo em vias de extinção.

Edgar Morin 


\section{Introdução}

O cinema brasileiro sempre produziu filmes de época (a primeira produção de $O$ Guarani de Vittorio Capellaro é de 1916).

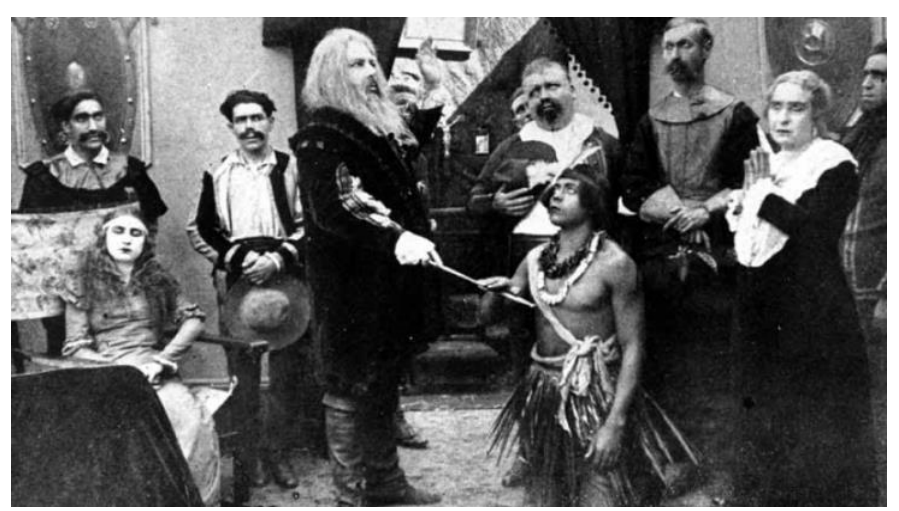

Figura 1 - Cena do filme $O$ Guarani - Enciclopédia do Cinema Brasileiro

Hoje, apesar de não possuirmos uma produção industrial, nos moldes de Hollywood, estamos mais maduros. Temos uma produção de época relevante. Desde a chamada retomada do cinema brasileiro, nos anos 90 do século $\mathrm{XX}$, estamos reconquistando o público e atingindo novas plateias.

\begin{tabular}{|c|c|}
\hline FILMES LANÇADOS & 1.154 \\
\hline RENDA TOTAL " [1.082 FILMES] & $\mathrm{R} \$ 2,07$ MILHÕES \\
\hline PÚBLICO TOTAL * (1.082 FILMES] & 251,5 MILHÕES \\
\hline MÉDIA RENDA POR FILME & $\mathrm{R} \$ 1,91$ MILHÃO \\
\hline MÉDIA PÚBLICO POR FILME & 232,4 MIL \\
\hline MÉDIA LANÇAMENTOS PORANO & 57,7 FILMES \\
\hline
\end{tabular}


Os anos 90 foram um marco para o cinema nacional. Questões políticas e econômicas interferiram de forma contundente na indústria e no mercado cinematográfico.

O cinema nacional paralisou a produção de longas-metragens no início do governo de Fernando Collor de Mello, por conta do fechamento dos órgãos que sustentavam a produção e a distribuição do cinema nacional, como a Embrafilme (Empresa Brasileira de Filmes, 1969-1990), o Concine (Conselho Nacional de Cinema 1976-1990) e a Fundação do Cinema Brasileiro (1988-1990). Com isso, o número de salas de exibição e de espectadores foi reduzido drasticamente e milhares de profissionais da área ficaram sem trabalho, migraram para a televisão e a publicidade ou deixaram o país.

Cabe aqui lembrar outro fato, acontecido no mesmo governo e retratado no filme Terra Estrangeira (Walter Salles,1995): O então presidente, Collor de Mello, confiscou as poupanças em banco do povo brasileiro, causando uma catástrofe que não teve qualquer comparação na história e levou 800 mil pessoas a deixarem o país.

Walter, que na época buscava orçamento para o futuro candidato ao Oscar, Central do Brasil, por ter uma condição financeira privilegiada, foi para Europa. Lá decidiu fazer um filme de baixo orçamento, em preto e branco e com equipe pequena que viria a ser um dos mais significativos documentos deste momento da história do Brasil, podemos chamar de um trabalho sobre o corpo histórico ${ }^{1}$ que se consolida como objeto histórico sem perder sua flexibilidade de corpo, de bambu, que se move e se modifica com o tempo e suas interpretações, sem se quebrar e sempre gerando movimento. Terra estrangeira narra uma época de forma ao mesmo tempo incisiva e atemporal, deixando um belo desenho para a história deste episódio tão triste para nós.

10 termo "corpo histórico" surgiu durante as reuniões de orientação com a professora Denise Portinari e se tornou um fio condutor na forma de pensar o figurino de época. Não costumamos pensar nisso até alguém nos abrir os olhos para o fato de todos sermos corpos históricos, o que muda é a maneira de lidar com a questão. Estamos acostumados a lidar com fatos históricos e em geral os associamos a figuras ou personagens históricos. Porém, pensar que somos corpos históricos e que o tempo presente em que vivemos interfere no ol har que inclinamos para trás (Agamben) ao observar fatos passados gera um novo corpo histórico, não é um raciocínio corriqueiro. 
O cinema brasileiro sofreu um abalo com o fim da Embrafilme, em 1990, durante o governo de Fernando Collor de Melo. Até esse período a produção cinematográfica brasileira estava totalmente ancorada nesse modelo de produção estatal, que garantia o financiamento e a distribuição dos filmes. Houve também a extinção da cota de tela, que obrigava um número mínimo de exibições dos filmes nacionais. Essas mudanças ocorreram sem que nenhuma outra medida fosse adotada a fim de preservar os investimentos no cinema nacional. Somente em 1993, após uma série de negociações entre Estado e cineastas é que foi promulgada a lei 8.685, a chamada Lei do Audiovisual, que promove a "retomada" dos investimentos no cinema brasileiro. Cinema da Retomada é como ficou conhecida essa produção realizada a partir de 1995, no decorrer do governo Fernando Henrique Cardoso, com os recursos decorrentes da nova legislação. (CATELLI; CARDOSO, 2009) ${ }^{2}$

A resposta à crise viria com a chamada "retomada do cinema brasileiro"3, trazendo consigo grandes produções, grandes bilheterias (Carlota Joaquina, 1995, 1.286.000 espectadores, O Quatrilho 1996, 1.117 .154 espectadores, Guerra de Canudos, 1997, 655.016 espectadores, Central do Brasil, 1998, 1.593 .967 espectadores $)^{4}$ e indicações ao Oscar de filme estrangeiro ( $O$ Quatrilho, de Fabio

\section{Barreto e Central do Brasil de Walter Sales).}

Dos quatro exemplos citados, três são filmes de época, com diferentes temáticas, estéticas, épocas, lugares e métodos de produção, mas possuindo em comum uma busca pelo aprimoramento na qualidade plástica do produto final.

Será que poder-se-ia traçar um perfil de produção que permeie esses primeiros filmes de época da retomada?

Maiores orçamentos (em alguns casos), longos períodos para executar os projetos (em outros), a responsabilidade de estar "ressuscitando" nosso cinema e a vontade de voltar e fazer melhor podem ser fatores relevantes para essa resposta. Talvez estejamos falando aqui de um movimento que, no início, se fez tão forte pela vontade de profissionais que tinham a gana e o desejo de voltar a fazer cinema com prazer e, foi isso que se refletiu nas telas!

Vivemos num país continental que produz filmes com as mais diversas caras, histórias e culturas e não possuímos no Brasil pesquisas que relatem os processos e projetos de pesquisa para a construção de um figurino de época de

A esse corpo que se constrói a cada momento da história e que se destrói ou se reconstrói a cada nova virada chamamos de corpo histórico, a transformação desse corpo histórico em elementos palpáveis, como livros, filmes, quadros etc., chamaremos de "objeto histórico".

${ }_{2}^{2}$ Revista Universitária do Audiovisual, UESC,) http://www.rua.ufscar.br/o-cinema-brasileirocontemporaneo-retomada-e-diversidade/

${ }^{3}$ Ver capítulo 2

${ }^{4}$ Dados da Agencia Nacional de Cinema (ANCINE) 
cinema. A maior parte do público desconhece a existência de uma direção de arte, um cenário e um figurino e quais as atribuições de cada setor.

Se analisarmos o figurino de um filme, será possível perceber o corpo histórico de um personagem e de uma época interpretados e construídos por um autor: o figurinista. O figurinista, ao pesquisar, situa historicamente a época em questão e, a partir daí, constrói um novo corpo histórico, uma nova construção dessa época sob o olhar do criador e do momento, do tempo em que ele vive.

Em design, chamamos de identidade visual o conjunto de elementos formais que representa, visualmente, um nome, uma ideia, um produto, uma instituição. O processo de criação dessa identidade passa por um briefing (conceito, ideia geral) fornecido pelo cliente, depois vêm as reuniões de criação (estamos falando das produções em equipe, como no cinema), que geram um processo que começa com a elaboração de um projeto e culmina com a concretização de um produto final.

Aqui podemos fazer uma analogia com o processo de criação e construção de um figurino. Nosso briefing é o roteiro, quando se estabelece um desenho geral de cada personagem. Nossas reuniões se dão com o diretor, o ator (construção da personagem), o diretor de fotografia (cor e materiais, refração etc.), produção (custos e viabilidade dos materiais utilizados, cronograma de produção). O projeto e o processo são o que relataremos aqui, no capítulo 3, Vestindo o Cinema e o produto final é o que se vê na tela, a identidade visual de cada personagem do filme como células, unidades que devem harmonizar em um todo, uma peça de um vitral que vai funcionar junto com as outras e, só assim, formar um desenho.

A maneira de se vestir, os tecidos e acessórios escolhidos, as cores, tramas e estampas são o retrato imaginado e minuciosamente construído de um personagem, de um local e de uma época da história. Sua classe social, sua personalidade e a forma com a qual lidou com o tempo em que viveu estarão "imaginarizadas" ali como uma impressão, um selo, uma marca. A isso chamamos de corpo histórico do personagem fílmico. Ali está o desenho do figurinista.

A forma de combinar e organizar essas informações na construção de uma imagem é o fazer do figurinista. O cenário e o figurino são elementos que vestem uma história. É através deles que se desenha a aparência do ambiente e das personagens, que a trama toma corpo no tempo e no espaço.

Com um relato do processo de criação de um figurino; o trabalho de reconstituição de época, as pesquisas de material, a construção dos personagens, a 
elaboração das peças até o filme chegar às telas; além das experiências e vivências pessoais dos criadores, é possível demonstrar a importância do trabalho de pesquisa tanto para a construção do espaço e do tempo fílmicos, quanto para a construção de uma realidade imaginária que se concretiza no filme.

Um figurino é uma imagem, uma materialização de um sujeito, real ou ficcional. É a representação formal (visual) de um personagem que, até então, era uma referência literária apresentada no roteiro, mas é também, a construção de um corpo histórico, uma recriação ficcional desse corpo histórico datado, numa nova época, sob um novo olhar.

O processo de elaboração dessa imagem (baseada em complexa pesquisa visual, antropológica, histórica, material) dentro do tempo fílmico, para a construção e concretização de uma forma visual é o objeto do presente trabalho.

Este projeto partiu de uma monografia (orientada pela professora e pesquisadora Maria Augusta Rodrigues) escrita sobre uma experiência pessoal; o trabalho de pesquisa e realização do figurino do filme $O$ Quatrilho", de Fabio Barreto em 1994/1995, no auge da retomada. Com base nos moldes deste projeto de produção e construção de figurino, realizados pela autora desta dissertação, foi mais fácil observar e compreender o método de criação e pesquisa de outros figurinistas atuantes no mesmo período.

Para completar a pesquisa, escolhemos os filmes Carlota Joaquina, a princesa do Brasil (Carla Camurati,1995) e Guerra de Canudos (Sergio Rezende, 2006). Dirigindo o foco para o trabalho de dois outros realizadores, foi possível produzir um material útil tanto aos profissionais do ramo como aos apreciadores de cinema e do design.

No capítulo 2 "Vestindo o cinema brasileiro", fazemos um passeio pela história do filme de época no Brasil e alguns de seus figurinos mais emblemáticos. Para tal, foram de grande valia a dissertação de mestrado A Indumentária de época e a arte de Luiz Carlos Ripper no cinema brasileiro, de Jefferson Ribeiro Peixoto e pesquisas de arquivo, revistas e livros.

O capítulo 3 "Vestindo o Cinema" é o eixo temático desta dissertação e está calcado nos estudos de caso de três filmes que fizeram bilheterias significativas nos anos 90: O Quatrilho, de Fabio Barreto, Carlota Joaquina, a princesa do Brazil de Carla Camurati e Guerra de Canudos, de Sergio Rezende. É importante 
lembrar que, nos filmes escolhidos, temos presentes três formas do cinema de época: a alegórica, a realista e a histórica.

Entrevistas com os figurinistas Emilia Duncan, Marcelo Pies e Beth Filipecki (Carlota e Guerra de Canudos, respectivamente) e com o diretor Sergio Rezende, além do depoimento pessoal da autora sobre $O$ Quatrilho complementam o capítulo.

No capítulo 4, "Desenhando cinema, projetando figurino - design e cinema, a construção de uma identidade/forma visual", fazemos uma analogia do trabalho do figurinista com o do designer.

Um dos conceitos relevantes na construção de uma identidade visual é a questão da cor e das formas. Neste capítulo trabalharemos esta questão, desde as teorias de Pastoureau sobre as listras, passando por Goethe até a psicologia e a psicodinâmica da cor na comunicação e no cinema. Aqui teóricos como Israel Pedrosa (Da cor a cor inexistente), Modesto Farina (Psicodinâmica das cores em comunicação) e Jacques Aumont (O olho interminável: cinema e pintura) estarão presentes, bem como exemplos de filmes que brincam com a cor como $O$ cozinheiro, o ladrão, a mulher e o amante (Peter Greenaway), Moulin Rouge (Baz Luhrman), Abril Despedaçado (Walter Sales).

$\mathrm{Na}$ conclusão, vamos examinar as relações que podem ser estabelecidas entre a identidade visual projetada pelo figurino dentro do filme e a possível identidade visual que permeia as produções dos anos da retomada.

É importante mencionar o fato da autora ser figurinista profissional desde 1984, o que foi de grande relevância para o formato da pesquisa. 


\section{2}

\section{Vestindo o Cinema Brasileiro}

A imagem de Zezé Motta como Xica da Silva pelas ruas do Arraial do Tijuco, atual Diamantina - Minas Gerais, recém alforriada e incontrolavelmente alegre, em um caminhar saltitante e eufórico correspondido por suas mucamas. A música de Jorge Ben - "Xica da/Xica da/Xica da Silva, a negra"- acompanha a cena e virou uma espécie de hino que compõe o imaginário sobre a personagem. Imaginário que o filme de Cacá Diegues em 1976 ajudou a construir - até então, o desfile campeão e revolucionário da escola de samba Acadêmicos do Salgueiro, na Avenida Presidente Vargas em 1963, era a principal referência imagética na construção popular da personagem. Na cena do filme, a liberdade de Xica se reflete no dourado do vestido e da peruca; ela, junto com a comitiva de escravos, forma uma mancha luminosa no espaço da cidade, contrastando com a sobriedade e escuridão dos trajes dos transeuntes nas ruas mineiras de pedra. (Peixoto, 2015, p. $)^{5}$

Livros sobre cinema brasileiro há muitos, de diversos autores e diversas origens, porém, o cinema de época no Brasil tem sobre si uma sombra literária. Raros são os títulos específicos sobre produções de época ou históricas brasileiras; menos ainda sobre seus figurinos.

Nosso recurso foi buscar artigos, dissertações, teses, publicações acadêmicas que nos dessem alguma luz sobre o tema. A dissertação de Jefferson Peixoto (A Indumentária de época e a arte de Luiz Carlos Ripper, 2015) veio num momento crucial de nosso trabalho, com dados e imagens que poderiam, se fosse o caso, ser reproduzidos na íntegra aqui. O livro Vestindo os nus, de Rosane Muniz também foi uma referência de peso, apesar de tratar, basicamente de teatro, nos dá uma visão consistente da construção do personagem e da importância do figurino para a mesma.

\footnotetext{
${ }^{5}$ Xica da Silva é o trabalho mais popular de Luiz Carlos Mendes Ripper (1943 - 1996) cenógrafo e figurinista, que deixou sua marca no teatro e no cinema brasileiros. A indumentária do Brasil do século XVIII, neste filme, recebe cores e formas e plumas e brilhos que, somadas a força e iconicidade da personagem-título, garantem instantes representativos não somente da proposta bem-humorada desta narrativa histórica, mas do papel do figurinista como integrante determinante na construção da imagem de um tempo e de um país.
} 
Uma lacuna grave na nossa literatura se abre quando falamos de Anísio Medeiros, um dos maiores nomes do cenário e figurino brasileiros. Não há livros sobre Medeiros, todas as informações possíveis vêm da internet, de profissionais da área que conviveram com ele ou com sua obra ou de acervos como o da FUNARTE (Fundação Nacional de Artes).

Seguindo a linha desenhada por Jefferson traçamos uma trajetória. Seria possível pensar outra estrada para percorrer, porém, esta nos pareceu adequada e bem calçada.

Romances e episódios históricos se revelam como uma rica fonte de material para os primeiros cineastas no Brasil - em sua maioria emigrantes - pois condensam na mesma obra a tentativa industrial (progresso) e o tema nacional (construção simbólica da memória nacional). A indumentária a ser vista na tela, então, deixa de ser mero traje e passa a ser figurino - figurino de outro tempo [...] (PEIXOTO, 2015, p.29)

Peixoto divide seu primeiro capítulo, Cinemas brasileiros que revelaram épocas - ou vice-versa, em três períodos: INCE (Instituto Nacional de Cinema Educativo) e Humberto Mauro, Vera Cruz e Cinema Novo. Nós acrescentamos os estúdios Cinédia e Atlântida ao que se chamou "período dos grandes estúdios" e o "período da retomada".

A presença do INCE se justifica por sua grande produção e representatividade no cinema brasileiro e pela realização de produções de época inspiradas na literatura brasileira. Faz-se necessário, apesar de não ser nosso foco principal, esclarecer o que foi o INCE e seu viés político e ideológico.

Os grandes estúdios, o nome já diz, justificam sua presença por serem as primeiras e significativas tentativas de instaurar uma indústria cinematográfica no Brasil (no caso, nos moldes americanos). Lembrando que existe uma contemporaneidade entre os primeiros grandes estúdios e o INCE, assim como com o pensamento positivista.

O cinema novo aparece como uma nova estética e linguagem, uma quebra de paradigmas.

A retomada do cinema brasileiro é nosso tema principal e a dividiremos aqui, seguindo a metodologia usada pela revista Filme $B$ em três fases: A primeira vai de 1995 com os lançamentos de Carlota Joaquina, a princesa do Brasil, de Carla Camurati e O Quatrilho, de Fabio Barreto, até 2002 com Cidade de Deus, 
de Fernando Meirelles. A segunda começa em 2003, quando a produção nacional alcançou mais de $21 \%$ de participação no mercado brasileiro e vai até 2007 com Tropa de Elite 1, de José Padilha. A terceira, começa em 2008, com a entrada em operação do Fundo Setorial do Audiovisual (um dos grandes responsáveis pela viabilidade das produções desde então) até os dias de hoje.

\section{1 - INCE - Instituto Nacional de Cinema Educativo}

Fundado por Edgar Roquette-Pinto (1884-1954) em 1936 durante a ditadura de Vargas, o Instituto Nacional de Cinema Educativo foi a consolidação de um pensamento reverberante no Brasil desde o final da década de 1920, de vinculação do cinema como instrumento educacional e de propaganda. Caberia ao filme uma utilidade cívica de instruir e educar (...). (Por Elis Galvão Publicado em 27 de Setembro de 2007- Revista Moviola)

Nos seus Ensaios de Antropologia Brasileira o antropólogo e professor Edgar Roquette-Pinto destaca que o homem brasileiro precisa ser assistido e educado e não substituído. Esta premissa está presente também no seu projeto de implantação do cinema educativo no país. Roquette-Pinto foi o idealizador e responsável pela criação do Instituto Nacional do Cinema Educativo (INCE), criado em 1936 e que teve a maior parte dos seus filmes dirigidos pelo mineiro Humberto Mauro.

O INCE, órgão financiado pelo governo de Getúlio Vargas, visava levar a educação aos lugares mais recônditos do Brasil. De 1936 a 1966, o instituto produziu curtas e médias metragens voltados para educação popular e divulgação de ciência e tecnologia. A exibição dos seus filmes era realizada em escolas, instituições culturais e nos cinemas, antes da projeção de longas metragens do circuito comercial.

Os filmes do INCE revelam o desejo de criar uma nova imagem do país. Seus documentários valorizam elementos nacionais tais como: a bandeira nacional, os registros da fauna e da flora e aspectos da cultura popular. Ou seja, 
uma visão positivista e, praticamente panfletária deste pensamento. Foi nesse ambiente que Humberto Mauro criou muitas de suas ficções baseadas em autores brasileiros, como Machado de Assis.

Inspirado em instituições europeias similares, que já estavam estabelecidas em países como França, Rússia, Itália, Alemanha e Inglaterra, o Instituto devia, além de servir à educação, transmitir a ideologia nacionalista do Estado Novo. O INCE transformou-se num dos pilares de um projeto mais amplo que objetivava organizar a produção cinematográfica do país, assim como o mercado exibidor e importador.

Roquette-Pinto, que esteve à frente do instituto de 1936 a 1947, acreditava que o cinema era um trunfo para compor um novo quadro, cuja base seria o desenvolvimento e a difusão da ciência. Isto expõe a influência do positivismo, vertente ideológica com a qual simpatizava. Para ele, era possível um novo país se todos tivessem acesso à ciência e ao conhecimento.

Humberto Mauro foi o principal cineasta do instituto. Após a saída de Roquette-Pinto e durante a direção do cineasta Flávio Tambelini, é que Mauro tem mais autonomia para trabalhar. Saem de cena os temas predominantes na primeira fase, mais ligados à pesquisa científica, e surge, com mais força, o mundo rural de Mauro. A historiadora Sheila Schvartman diz que é no segundo momento que o INCE se consolida como espaço de criação do cineasta e Mauro se aproxima dos modernistas ao valorizar o folclore. Na série Brasilianas, ele registra os cantos de trabalho e canções populares.

Os filmes do INCE, em geral, misturam documentário e ficção num modelo didático, com um apresentador no tempo presente que introduz o tema e uma parte ficcional, com figurinos criados para reproduzir a época em que a história se passa. É o caso do curta-metragem Um Apólogo (1939) de Mauro, inspirado na obra de Machado de Assis, analisado por Peixoto e que, ainda possui um terceiro elemento, alegórico, nas cenas que se passam dentro da caixa de costura com os personagens Agulha, Linha e Alfinete "Se o conto machadiano sugere um paralelo entre os dois universos da fábula, na adaptação cinematográfica a indumentária é que torna ainda mais evidente a analogia entre as personagens femininas." (PEIXOTO, 2015, p. 47). Ainda segundo Peixoto “A indumentária (...) era julgada mediante dois valores: beleza e eficácia na reconstrução temporal” (PEIXOTO, 2015). 
Peixoto, em sua dissertação analisa os pormenores dos figurinos dos filmes de Mauro, $O$ Apólogo e $O$ Despertar da Redentora (sobre a princesa Isabel). Nosso objetivo aqui não foi esse (pois analisamos os filmes específicos do período da retomada), e sim fazer um levantamento geral de momentos relevantes da filmografia de época brasileira e o INCE, com Humberto Mauro, é um deles. Porém, reproduzimos aqui algumas imagens referentes ao filme citado por Peixoto, devido a sua peculiaridade em relação aos figurinos.
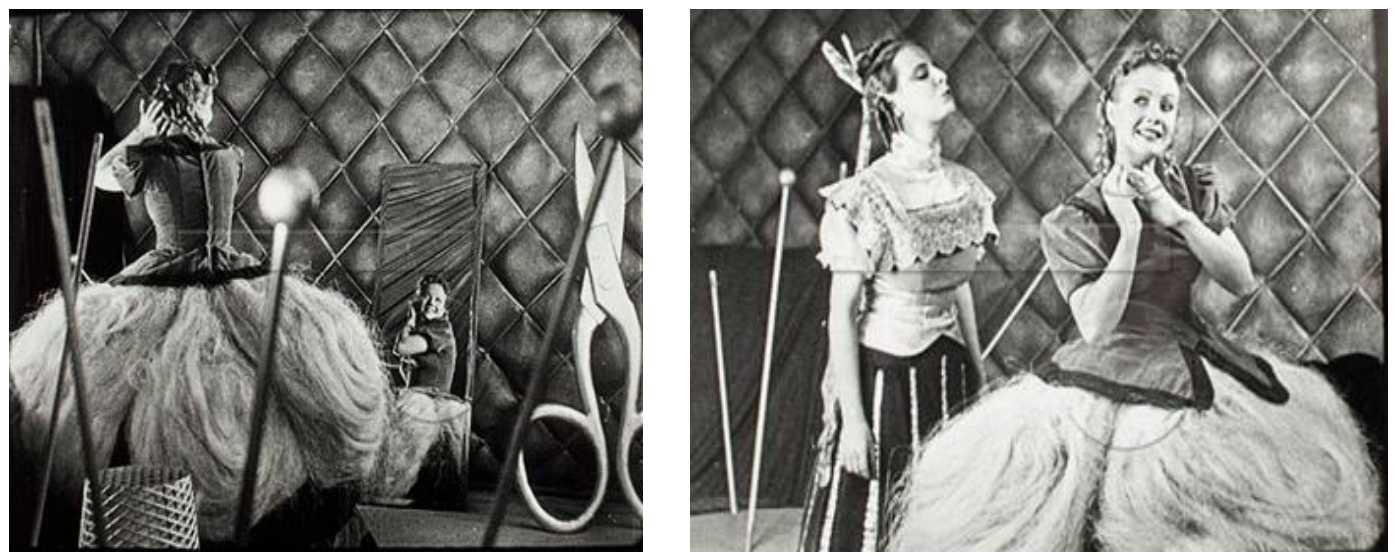

Figura 2 e. Figura 3 Cenas do filme $O$ Apólogo dentro da caixa de costura (personagens agulha e linha)

\section{2 - Os Grandes Estúdios}

A partir de 1930, a infraestrutura para a produção de filmes se sofistica com a instalação do primeiro estúdio cinematográfico no país, o da companhia Cinédia, no Rio de Janeiro. Em 1941 é criada a Atlântida, que centraliza a produção de chanchadas cariocas. A reação paulista acontece mais tarde com o ambicioso estúdio da Vera Cruz, em São Bernardo do Campo.

$\mathrm{Na}$ historiografia clássica do cinema brasileiro, quando nos referimos a "cinema de estúdio", apesar de várias experiências país afora, em geral são três os nomes que, imediatamente, vêm à tona: a Cinédia — exemplo inaugural que se costuma considerar como o modelo de um desejo de estúdio de verdade, especialmente ao longo dos anos 30 e início dos anos 40 - seguida da Atlântida, na segunda metade dos anos 40 e ao longo dos anos 50 e, finalmente, da Vera 
Cruz, no final da década de 40 e até a primeira metade dos anos 50 (Vieira, João Luis $)^{6}$

\subsubsection{Cinédia}

Em 1930, no Rio de Janeiro, o jornalista e cineasta Adhemar Gonzaga inaugura o que seria o modelo de estúdio de porte no país, fruto de campanhas por uma Industria cinematográfica nacional na década de 1920, encabeçadas pela revista Cinearte $^{7}$, dirigida pelo próprio Gonzaga e que buscava uma atualização técnica e estética capaz de colocar o cinema brasileiro no mesmo patamar da produção internacional. Nas palavras de Vieira "de acordo com o que aqui chegava da produção dominante norte-americana, celebrando um mal disfarçado racismo ao exaltar a hegemonia de um padrão de beleza branco onde fotogenia era sinônimo de ambientes luxuosos e higiênicos por onde circulavam, de preferência, corpos jovens e saudáveis." (Idem)

O estúdio se dedica a produzir dramas populares e ao que futuramente se denominaria "musicarnavalesco", seu grande trunfo e onde era possível conciliar o carnaval com cenários e figurinos sofisticados, inspirados no modelo hollywoodiano e a moderna tecnologia para a filmagem de musicais, que chegava ao país impulsionada pelas necessidades do recém-criado cinema sonoro.

Humberto Mauro assina o primeiro filme da companhia, Lábios sem beijos (1930) e, em 1933, dirige Ganga Bruta, considerado seu primeiro clássico. Com a comédia musical, Alô, alô, Carnaval (1936, Adhemar Gonzaga) estrelada por Carmem Miranda, a Cinédia tem seu primeiro estouro de bilheteria.

\footnotetext{
${ }^{6} \mathrm{http}: / /$ www.cpcb.org.br/artigos/industrializacao-e-cinema-de-estudio-no-brasil-a-fabrica-atlantida

${ }^{7}$ Cinearte - Ainda dentro de umaconcepção e desejo de implantação e desenvolvimento de uma indústria de cinema no Brasil, também seguindo o modelo bem consolidado do cinema norteamericano, a construção de um mercado consumidor no país foi alavancado pelo que Christian Metz chamou de "terceira indústria", ou seja, a mídia impressa, muito bem assentada por publicações especiais, com destaque absoluto para a revista Cinearte, editada ininterruptamente durante duas décadas a partir de 1926. Considerada derivativa da similar norte-americana Photoplay, tanto em seu aspecto gráfico quanto editorial, seu primeiro número se autoproclamava "um mediador natural entre o mercado brasileiro e o produtor norte-americano", exaltando e promovendo a universalidade do modelo de produção de Hollywood, apoiado em duas estruturas fortes e dominantes naquele cinema: o estrelismo (star system) e o cinema de estúdio.(Vieira, João Luis http://www.cpcb.org.br/artigos/industrializacao-e-cinema-de-estudio-no-brasil-a-fabricaatlantida/)
} 


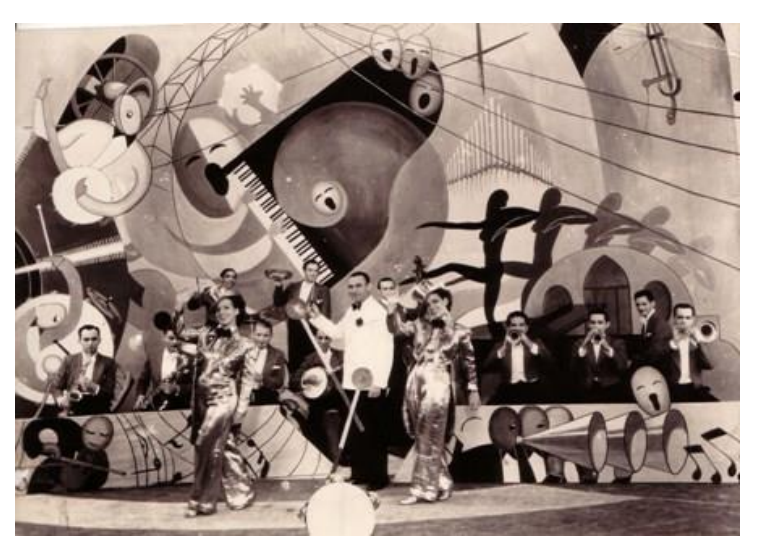

Figura 4 Cena Alô, alô, carnaval

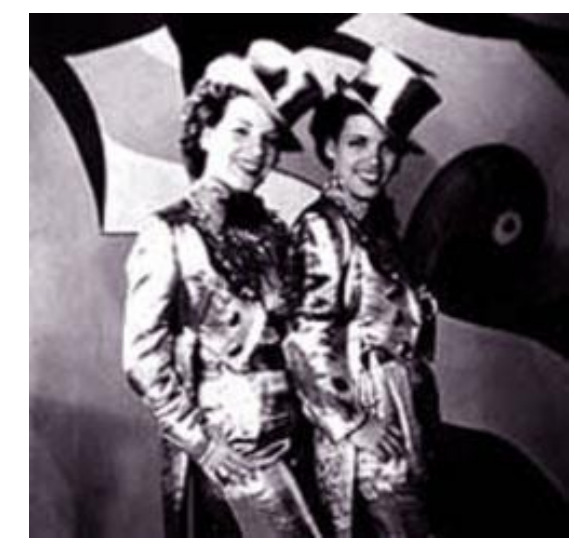

Figura 5 Cena Alô, alô, carnaval

Bonequinha de seda (1936, Oduvaldo Viana), no gênero musical opereta, foi o primeiro grande êxito artístico e financeiro da Cinédia e, segundo a Enciclopédia do Cinema Brasileiro, representou um marco artístico e técnico na sua história.

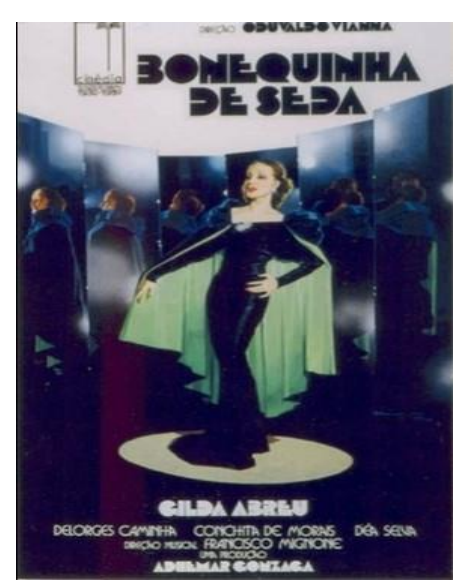

Figura 6 cartaz

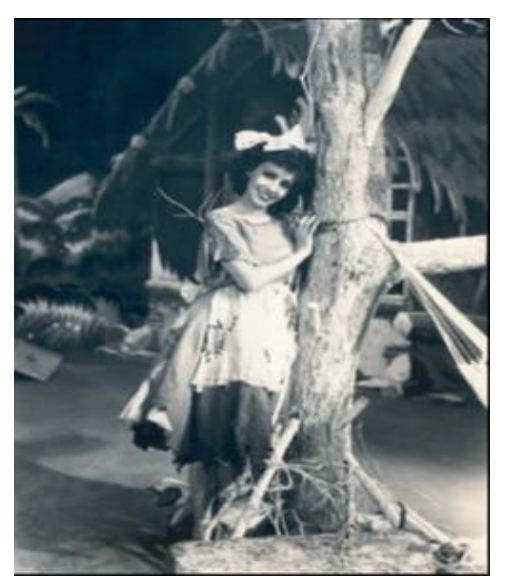

Figura 7 Cena do filme Bonequinha de Seda

\subsubsection{Atlântida (Atlântida Empresa Cinematográfica do Brasil S.A.)}

Fundada em 1941, no Rio de Janeiro, pelos irmãos José Carlos Burle e Paulo Burle, Moacyr Fenelon, Alinor Azevedo e Arnaldo Farias, com o apoio do Jornal do Brasil (onde lê-se o nome do conde Pereira Carneiro), A Atlântida instala seu primeiro estúdio, de pequeno porte, na sede do jornal. 
Estreia com produções que priorizam temas brasileiros, com pretensões artísticas, como Moleque Tião (José Carlos Burle, 1943) e É Proibido Sonhar (Moacyr Fenelon, 1943) seguindo o pensamento positivista que impera no país nesse período e que pretende a utilização do cinema como uma de suas principais ferramentas de divulgação de um "ideal brasileiro".

O sucesso, porém, viria com as comédias carnavalescas dirigidos por Watson Macedo Não Adianta Chorar (1945, com Oscarito e Grande Otelo), Este Mundo é Um Pandeiro (1947, idem), Carnaval no Fogo (1949, idem), Aviso aos Navegantes (1950, idem), com Anselmo Duarte no elenco. A partir daí predomina a chanchada, ${ }^{8}$ com baixo custo e grande apelo popular e filmes como Nem Sansão nem Dalila e Matar ou Correr (1954, Carlos Manga). Este gênero nos interessou particularmente porque abordava os temas de época com a leveza e o descompromisso da comédia, tendo a criatividade e o improviso como elementos principais e produzindo pérolas do figurino (ver fotos ).
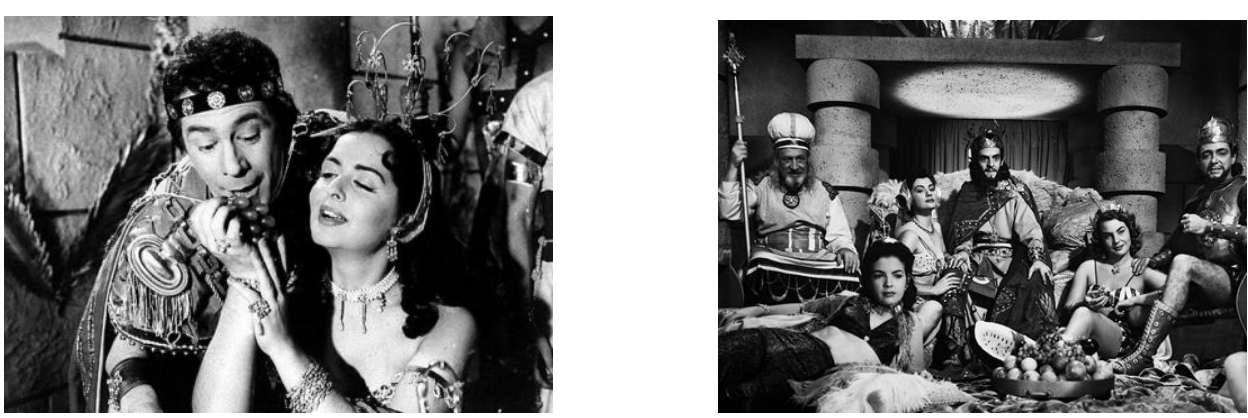

Figuras 8 e 9 -Cenas do filme Nem Sansão ne Dalila

8 - Gênero cinematográfico de ampla aceitação popular que melhor sintetiza e define o cinema brasileiro das décadas de 1930, 1940 e. principalmente, 1950, produzido majoritariamente no Rio de Janeiro. Diante de um mercado cinematográfico completamente dominado pela produção estrangeira, de origem norte-americana, a chanchada tornou-se [...] a forma mais visível e contínua de presença brasileira nas telas do país. A designação pejorativa, adotada por vários críticos de cinema, possui origem etimológica no italiano cianciata, que significa um discurso sem sentido, uma espécie de arremedo vulgar, argumento falso. (Enciclopédia do Cinema Brasileiro, p.117) 


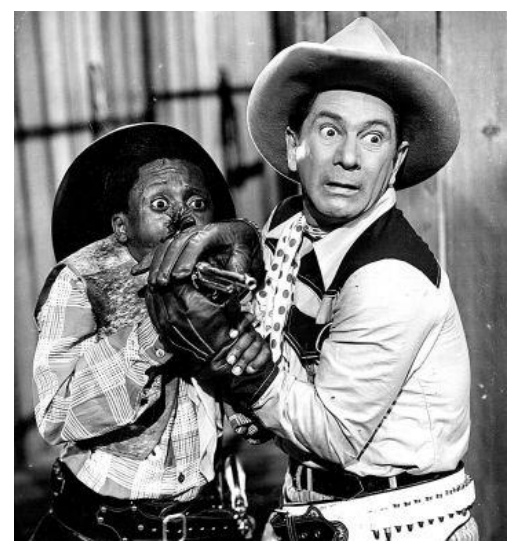

Figura 10- Cena do filme Matar ou Correr

Durante o sucesso das chanchadas, a Atlântida ainda produziu algumas adaptações literárias como Terra Violenta (1948) de Eddie Bernoudy (do livro de Jorge Amado, Terras do Sem Fim), Escrava Isaura (1949) de Eurides Ramos (do original de Bernardo Guimarães) ou o pioneiro melodrama racial Também Somos Irmãos (1949) de José Carlos Burle. Na década de 50, entre chanchadas e comédias, incluindo adaptações de peças como O Golpe (1955), Papai Fanfarrão (1956) e Cupim (1959), todas dirigidas por Carlos Manga, há que se destacar, sempre, produções de fôlego como A Sombra da Outra (1950), de Macedo, Areias Ardentes (1951), de J.B.Tanko, o filme noir Amei um Bicheiro (1952) de Jorge Ileli e Paulo Wanderley, além de uma coprodução com a Alemanha, Paixão nas Selvas (1955), dirigida por Franz Eichhorn.

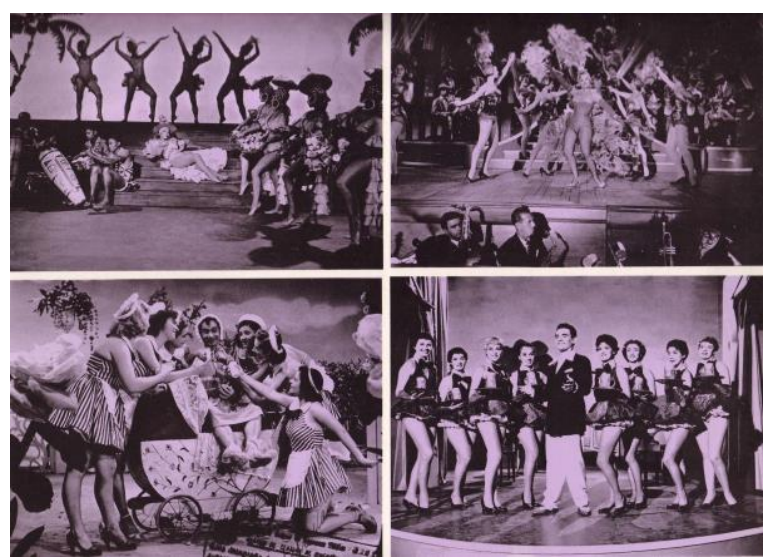

Figura 11- Cena do filme Assim era Atlântida (1975, Carlos Manga)9 


\subsubsection{Vera Cruz (Companhia Cinematográfica Vera Cruz)}

Mais moderna e ambiciosa que as duas anteriores, a Companhia Vera Cruz surge em São Paulo, em 1949 como um empreendimento grandioso. Tendo como fundadores dois membros da burguesia paulista, os industriais Francisco Matarazzo Sobrinho e Franco Zampari, representantes da próspera colônia italiana que acabara de criar o MAM (Museu de Arte Moderna) e o TBC (Teatro Brasileiro de Comédia.

Renegando a chanchada, a Vera Cruz se constrói sobre um modelo hollywoodiano, com profissionais europeus (na verdade, pessoas de mais de vinte e cinco nacionalidades trabalharam nos estúdios de São Bernardo dos Campos, SP). Nomes como o italiano Luciano Salce (Floradas na Serra, 1954), Adolfo Celli (Tico-tico no Fubá, 1951), e Alberto Cavalcanti (O Canto do Mar), que volta da Europa para dirigir a Vera Cruz.

A companhia busca um viés que mescla a narrativa hollywoodiana com temas brasileiros, como fica claro nos filmes Caiçara (1950) e no melodrama musical Tico-tico no Fubá (1951) de Celli, assim como no melodrama abolicionista Sinha Moça, (1952/1953), de Tom Payne, filme de época citado na dissertação de Peixoto (ver fotos na página seguinte).

\footnotetext{
${ }^{9}$ Assim Era a Atlântida reúne trechos dos principais filmes que sobreviveram a um incêndio nos estúdios da empresa, em 1952, e a uma inundação em seus depósitos, em 1971. Esses filmes foram reavaliados e recuperados através de um trabalho árduo e eficiente.
} 

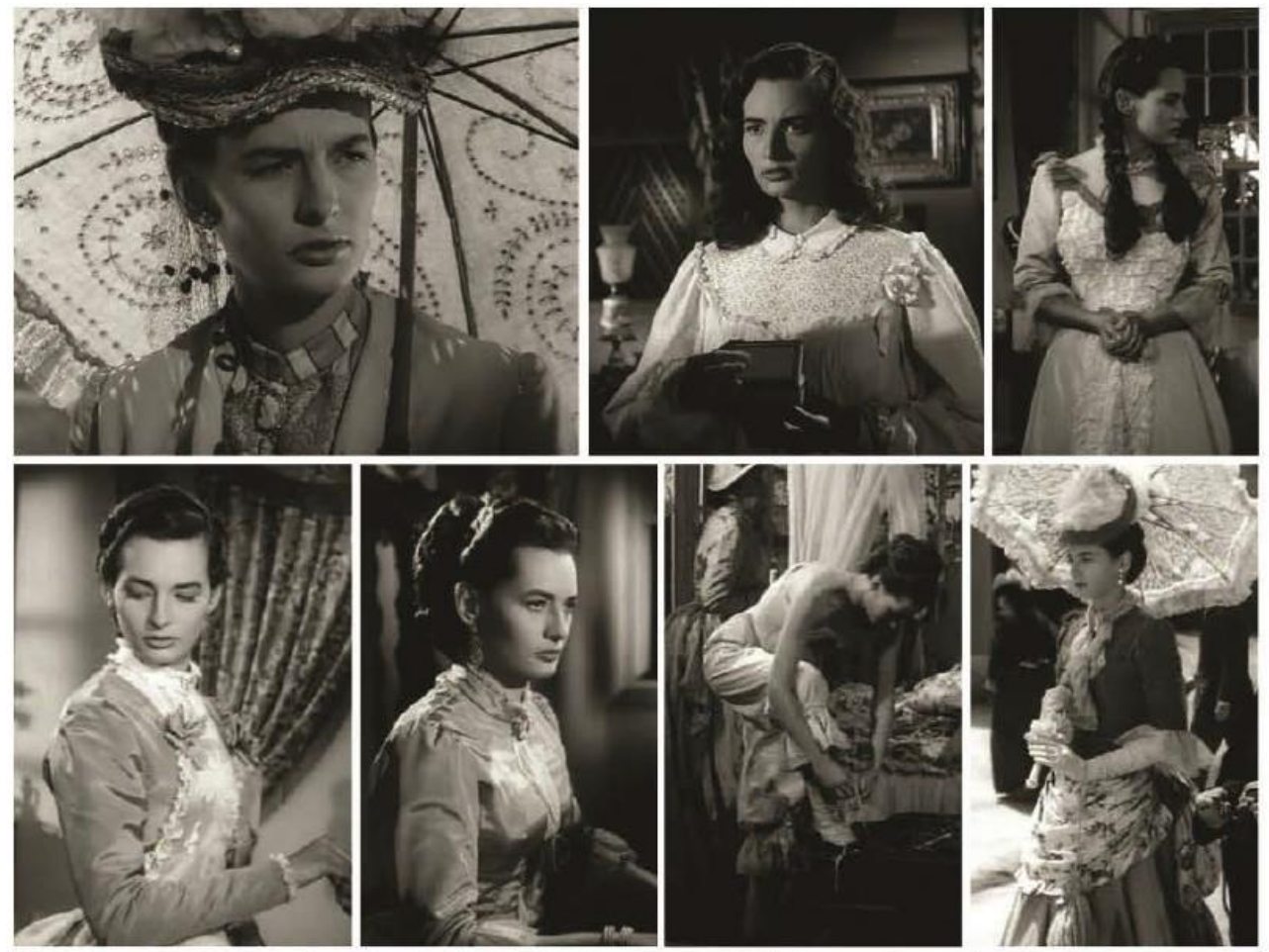

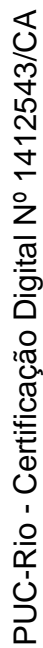

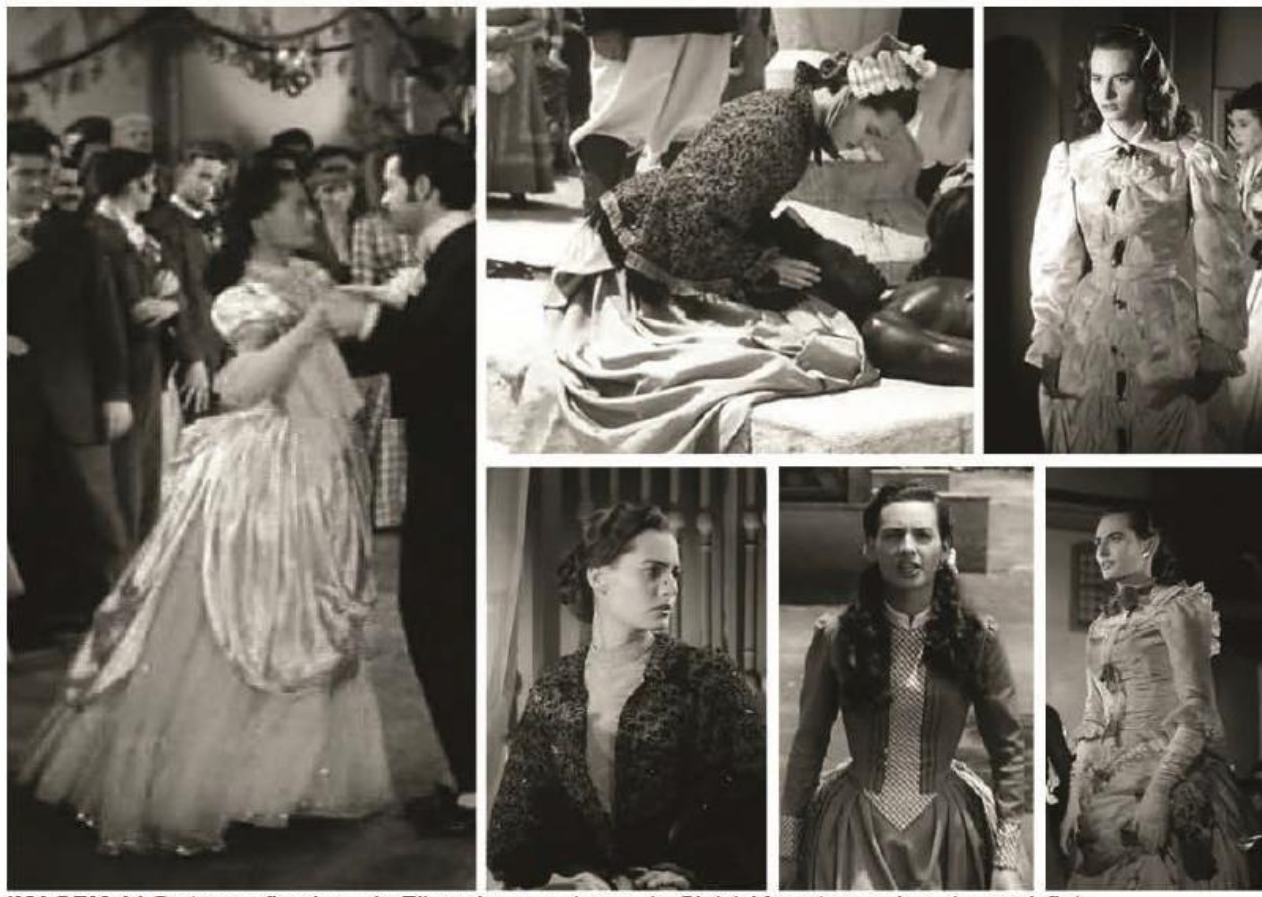

IMAGEM 4 | Os trezes figurinos de Eliane Lage ao longo de Sinhá Moça (por ordem de aparição).

Figura 12 Cena do filme Sinhá Moça ${ }^{10}$

${ }^{10}$ Fotos da dissertação de Peixoto, p.61 
O Cangaceiro (1953), de Lima Barreto, sucesso internacional premiado no Festival de Cannes, na França, inicia o ciclo de filmes sobre cangaço e reitera o viés nacionalista.

Representando as comédias de costumes da companhia, Amácio Mazzaropi ${ }^{11}$ é um de seus grandes salários, vivendo o personagem caipira mais bem-sucedido do cinema nacional.

Seguindo o modelo americano dos anos 1950, a Vera Cruz possuía um forte departamento de publicidade, que apostava no glamour dos atores e atrizes para divulgar seus filmes em revistas e periódicos, distribuindo fotos, informações de bastidor e releases dos filmes, criando mitos e aumentando bilheterias.
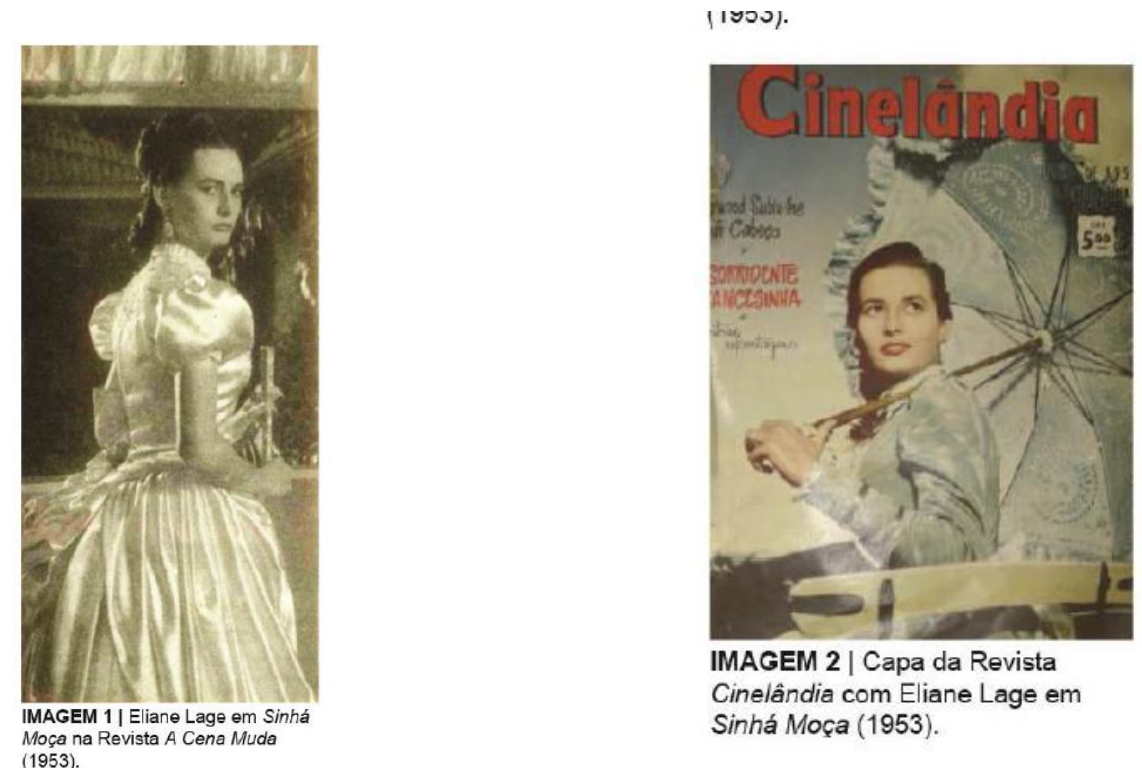

Figura 13- Cartaz de Revista com Eliane Lage (Sinhá Moça) ${ }^{12}$

\footnotetext{
11 (1912-1981) nasce em São Paulo. De família pobre, aos 14 anos foge de casa para ser ajudante de faquir, em uma trupe ambulante. Adquire sucesso fazendo números cômicos. Trabalha na Rádio Tupi, onde faz um programa em que conversa com os caipiras de São Paulo. Em 1952, é contratado pela Vera Cruz e realiza Sai da frente (1952), Nadando em dinheiro (1953) e Candinho (1954). O fim da companhia não interrompe sua carreira. Filma a seguir A carrocinha (1955), $O$ gato da madame (1956) e consagra-se com o caipira de Jeca Tatu (1959). Na década de 70, continua produzindo: Um caipira em Bariloche (1971) e A banda das velhas virgens (1979)

${ }^{12}$ Fotos da dissertação de Peixoto, p.58
} 


\section{3 - Cinema Novo}

[...] o Cinema Novo foi carioca e paulista, mineiro e nordestino, épico e intimista, realista e alegórico, branco e mulato, índio e algumas vezes negro, literário e musical, teatral e poético, pessimista e eufórico, trágico e cômico, com algumas pitadas melodramáticas, engajado e alienado, totalizante e parcial, crítico e contemplativo, messiânico e agnóstico, fatalista e ingênuo, sutil e histérico, apocalíptico e integrado, revolucionário e reformista, elitista e populista, saudosista e profético, nacionalista e cosmopolita, desesperado e orgiástico, machista e feminino, dionisíaco e careta, local e universal. (RAMOS e MIRANDA, org., 2000, p.145)

Faz-se necessário esclarecer aqui que o Cinema Novo entrou em nossa lista pela diversidade de filmes históricos, literários e de época que produziu e não pelo seu peso como movimento ou sua repercussão na história do cinema brasileiro (não teríamos a pretensão de desenvolver esta página tão rica e complexa da nossa cinematografia e nem seria este o lugar). A citação acima, retirada da Enciclopédia do Cinema Brasileiro, nos pareceu a melhor maneira de resumir o que foi esse movimento em termos de diversidade.

Segundo a Enciclopédia, determinar o início do Cinema Novo é mais fácil do que fechar o seu ciclo: final dos anos 1950 e início dos 60, nouvelle vague na França, neorrealismo na Itália, crise no sistema de estúdios e nos códigos narrativos tradicionais, pesquisas de linguagem, a política do autor e a valorização da mise-em-scène e da figura do diretor movimentam o território cinematográfico (principalmente, mas não só, europeu).

No Brasil ecoam os tambores europeus, reverberados por um número significativo de profissionais do meio formados nas escolas de cinema da Europa. Um forte movimento cineclubista e a chegada ao país de novas tecnologias (equipamentos mais leves e fáceis de manipular) contribuíram para a renovação dos documentários e as transformações significativas da linguagem de ficção e, consequentemente, dos temas históricos e literários.

A tudo isso é preciso agregar o peso decisivo de fatores extracinematográficos: o movimento estudantil e o Centro Popular de Cultura imprimem ao Cinema Novo uma sintonia perfeita com a efervescência intelectual do momento, com destaques para a música, a literatura, as artes plásticas, a literatura. (RAMOS e MIRANDA, org., 2000, p.144) 
Peixoto, em sua dissertação, elege dois filmes para trabalhar, Capitu (Paulo Cesar Sarraceni, 1968) e Os Inconfidentes (Joaquim Pedro de Andrade, 1972), quando trata do Cinema Novo, em seu capítulo Histórias, Indumentária e Cinemas Brasileiros, analisando detalhadamente seus figurinos. Ambos têm cenários e figurinos de Anísio Medeiros.

Uma lacuna grave na nossa literatura se abre quando falamos de Anísio Medeiros, um dos maiores nomes do cenário e figurino brasileiros. Não há livros sobre Anísio, todas as informações possíveis vêm da internet, de profissionais da área que conviveram com ele ou com sua obra ou de acervos como o da FUNARTE (Fundação Nacional de Artes) *13.

Como nosso objetivo aqui foi dar um panorama geral das fases do cinema brasileiro e suas produções de época, abrimos um pouco mais o nosso leque para citar alguns dos filmes cujos figurinos nos pareceram merecedores de crédito durante o período (mais ou menos definido) do Cinema Novo, contemplando seus diretores mais emblemáticos. Alguns destes filmes e seus figurinos, aparecem no capítulo 2 de Peixoto Luiz Carlos Ripper e o Cinema Brasileiro, por terem sido assinados pelo figurinista.

Deus e o Diabo na Terra do Sol (Glauber Rocha, 1964), segundo filme de Glauber, marco do Cinema Novo e da famosa frase do diretor "Uma ideia na cabeça e uma câmera na mão", esta alegoria sertaneja inovou a linguagem cinematográfica com sua construção, plástica e movimentos de câmera. O figurino, de Paulo Gil Soares, atemporal e alegórico, acompanha a estética do filme.

13 Paralelamente à sua atuação em teatro, Anísio é também um profissional da área de cinema, tendo estreado em Capitu, de Paulo César Sarraceni, filme que ele próprio considera como um dos únicos enganos de sua carreira. De Capitu até Os Inconfidentes, Lição de Amor, Dona Flor, Joana Francesa, dentre outros, foi um pequeno passo. Discorrendo sobre o campo de trabalho que os dois tipos de atuação requerem, ele coloca uma diferença fundamental: em teatro, existem "mil olhos estáticos" (os espectadores) e, em cinema, "um olho móvel" (câmera), embora tratar da forma com duas linguagens seja um trabalho de etapas quase idênticas. (...)

(PORTAL DA FUNARTE: www.funarte.gov.br/.../acervo/cenario-e./biografia-de-anisiomedeiros) 


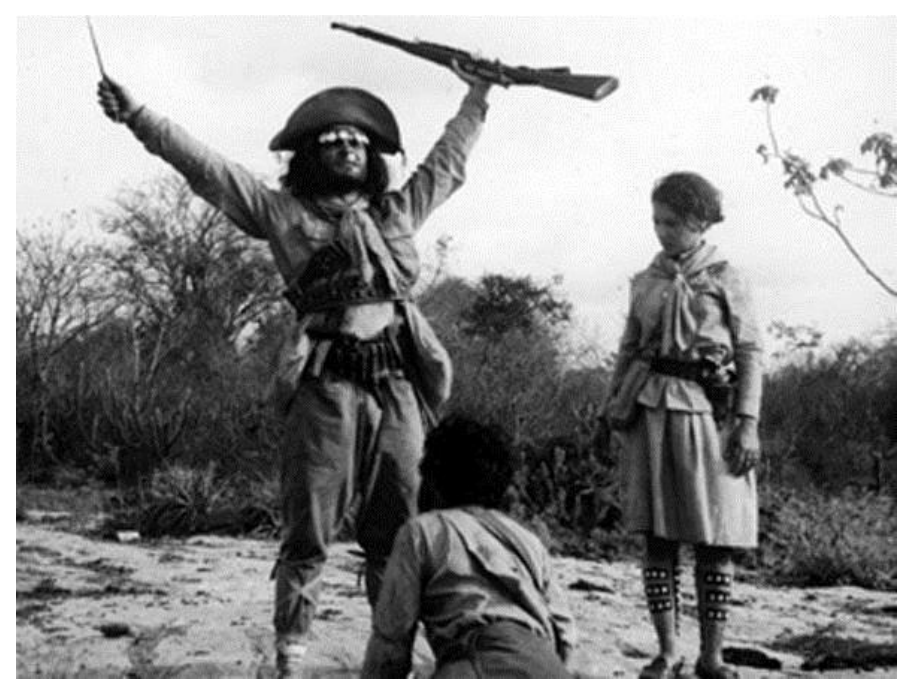

Figura 14 - Cena do filme Deus e o Diabo na Terra do Sol

Os Herdeiros (Cacá Diegues, 1969), conta a saga de uma família brasileira de 1930 a 1964, dividindo a história em "capítulos" com datas, sendo algumas históricas: "Fazenda São Martinho - 26 de julho de 1930”, "São Martinho - 30 de outubro de 1945”, Rádio do Povo - agosto de 1954”, etc.

\begin{abstract}
Nessa assemblage estético-nacional, envernizada pelo esforço em arquitetar uma memória do Brasil partir de olhar analítico lançado do contemporâneo, a indumentária do filme, à medida que acompanha as transformações inerentes ao fluxo do tempo, materializa identidades sem anular o traço incisivo do figurinista. (PEIXOTO, 2015, p.92)
\end{abstract}

Neste filme de época, Diegues parte do particular (a família), para contar uma etapa da história brasileira, onde o figurino de Luiz Carlos Ripper acompanha as mudanças de época e contribui na passagem de tempo. 

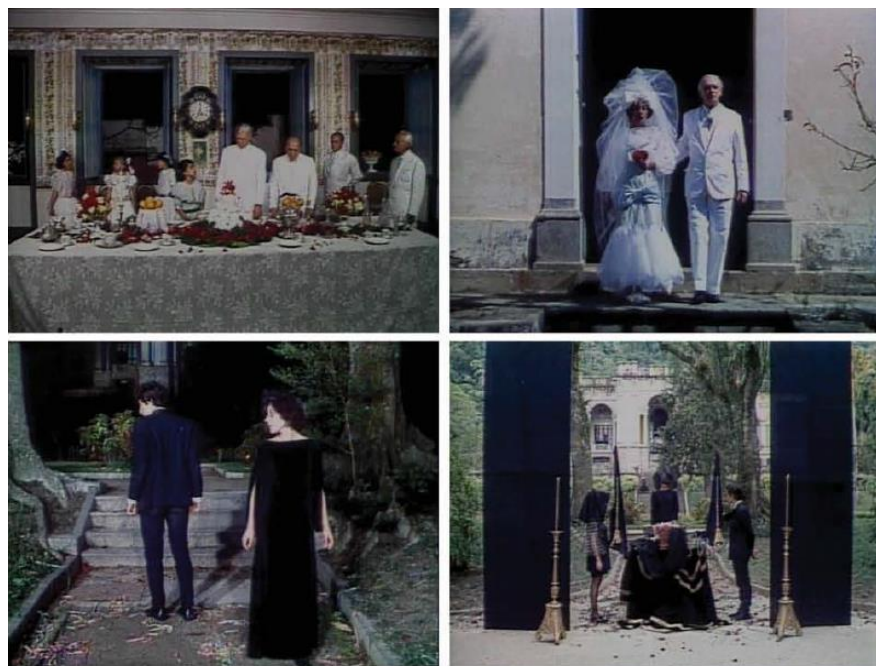

Figura 15 cenas do filme Os Herdeiros

Capitu (Paulo Cesar Sarraceni, 1968), adaptado do livro Dom Casmurro, de Machado de Assis e com roteiro assinado pelo diretor em parceria com Lygia Fagundes Telles e Paulo Emilio Salles Gomes - cenário e figurino de Anísio

Medeiros - usa o figurino de forma plasticamente psicológica, como explica Peixoto, para marcar o tempo. $\mathrm{O}$ contraponto masculino e feminino, trazendo à baila a questão de gênero do original de Machado, reflete-se (segundo Peixoto) nos costumes, na moral e na vestimenta, opondo forma, cor e tecido das roupas para enfatizar as diferenças.

No início da narrativa, a extensa crinolina que dá forma à saia- balão e os ombros perdidos em babados resultam num corpo em forma de $\mathrm{X}$, alvo e puro, ainda incapaz de cultivar a desconfiança de Bento Santiago. Já próximo ao fim, o corpo da personagem-título já não tem a não tem a forma simétrica do princípio - o volume se concentra na parte posterior do quadril (PEIXOTO, 2015, p.64)

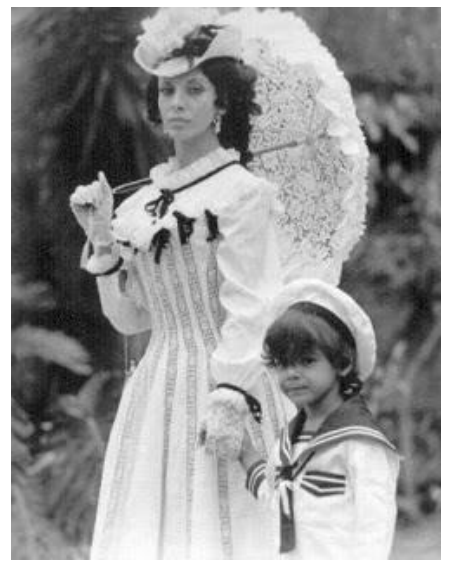

Figura 16

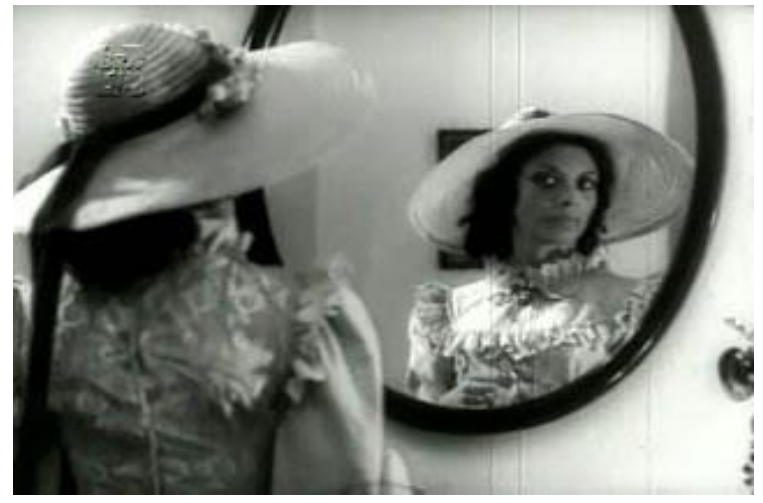

Figura 17- Cenas do filme Capitu 
Pindorama (Arnaldo Jabor, 1970), mostra ao espectador, logo na primeira cena, a legenda: “ No século XVI, quando éramos colônia de Portugal, nasciam aqui os traços primitivos de nosso caráter nacional”, à primeira vista, um indício do que se chama de filme histórico clássico, porém, com o passar das cenas veremos que estamos diante de uma alegoria típica do cinema novo. Seja para fugir da censura, como sugerem alguns comentaristas de cinema, ou por uma opção estilística desenvolvida pela efervescência do momento histórico e artístico, como preferem outros, precisamos ver este filme dentro do contexto da época e da proposta desta forma de fazer cinema (como seria bom que víssemos qualquer filme, de qualquer época). Ripper utiliza uma plástica e, aparentemente, uma prática, teatrais na construção de uma estética alegórica, sem fugir das referências históricas do século XVI.
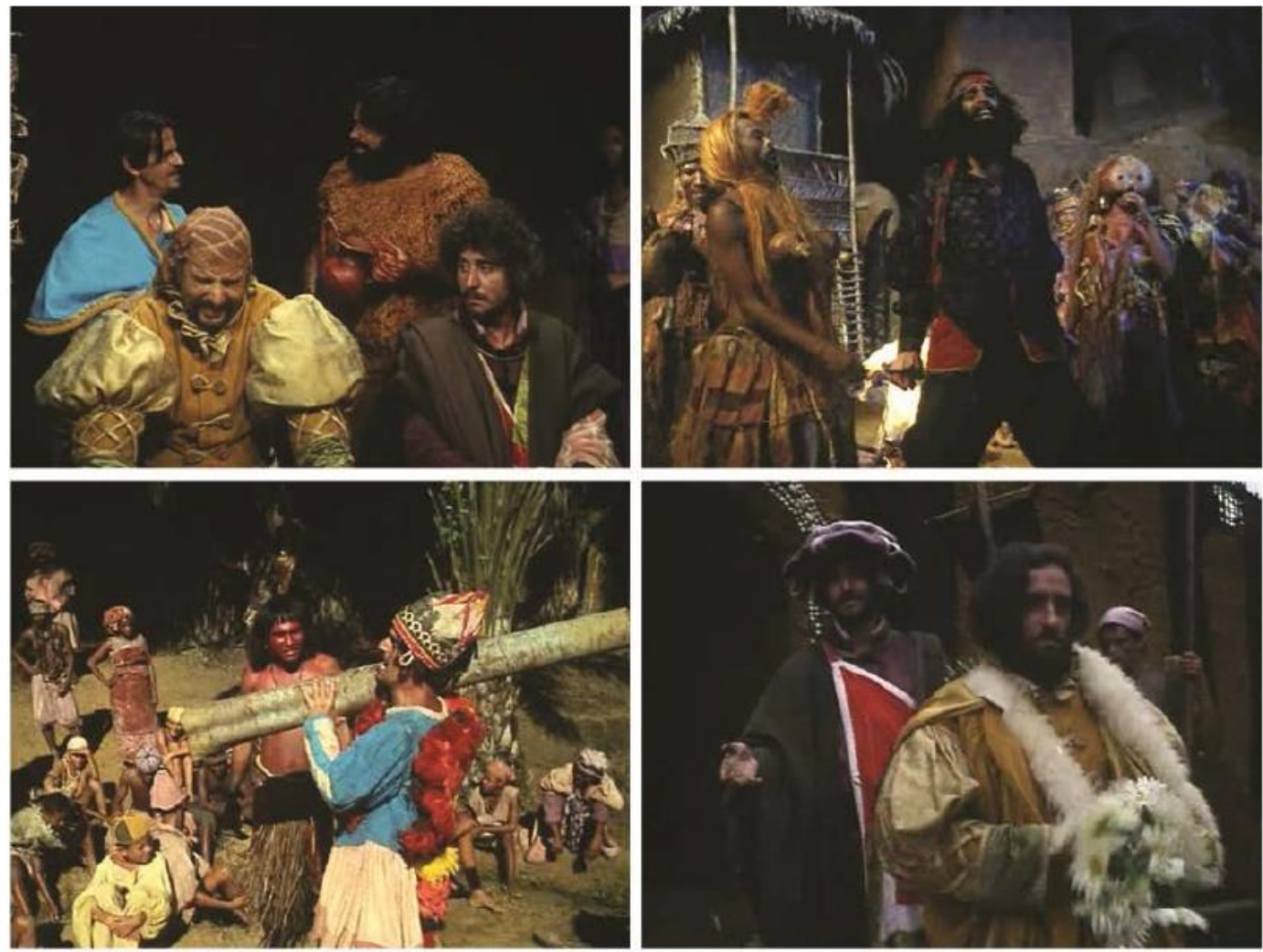

IMAGEM 2 | 0 figurino de Pindorama como reforço da linguagem teatral do filme.

Figura 18 Cenas do filme Pindorama ${ }^{14}$

\footnotetext{
${ }^{14}$ PEIXOTO, p. 100
} 
Como era Gostoso meu Francês (Nelson Pereira dos Santos, 1971), deixa clara a valorização, por parte de Nelson Pereira dos Santos, do papel dos povos indígenas como formadores da cultura brasileira. Ao apresentar a sociedade Tupinambá em sua complexidade, e não como meros guerreiros comedores de homens, o diretor transmite que, antes da chegada dos europeus, já haviam culturas aqui e que essas não se submeteram à "superioridade branca", seja qual fosse a nação.

Baseado nos diarios de Hans Staden e inspirado nas imagens de Theodore de Bry ${ }^{15}$ a cenografia de Regis Monteiro e o figurino de Mara Chaves seguem de perto as referências, como se vê nas imagens abaixo.

${ }^{15}$ https://upload.wikimedia.org/wikipedia/commons/7/7e/Theodore_de_Bry_America tertia_pars_1.jpg 


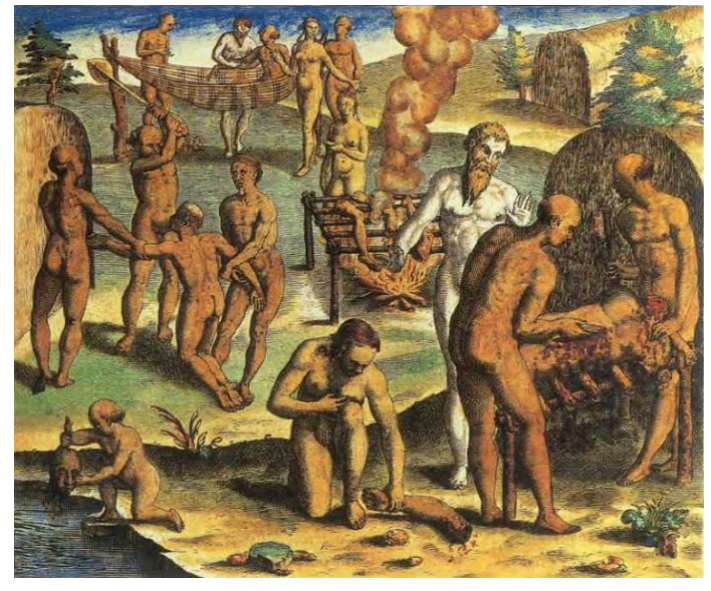

Figura 19 Theodore de Bry

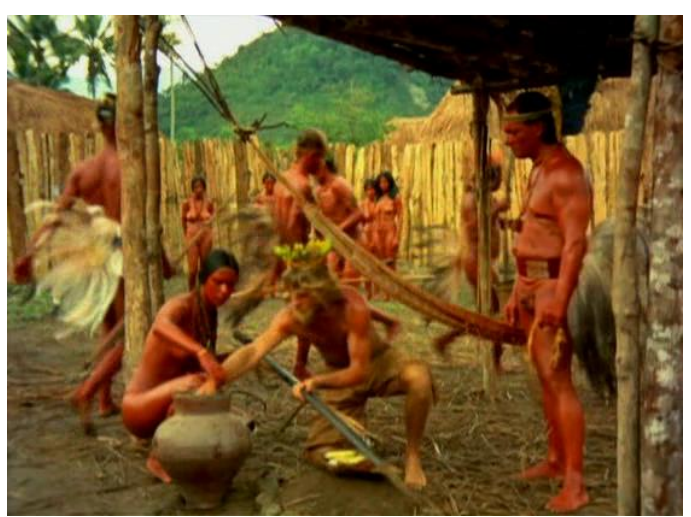

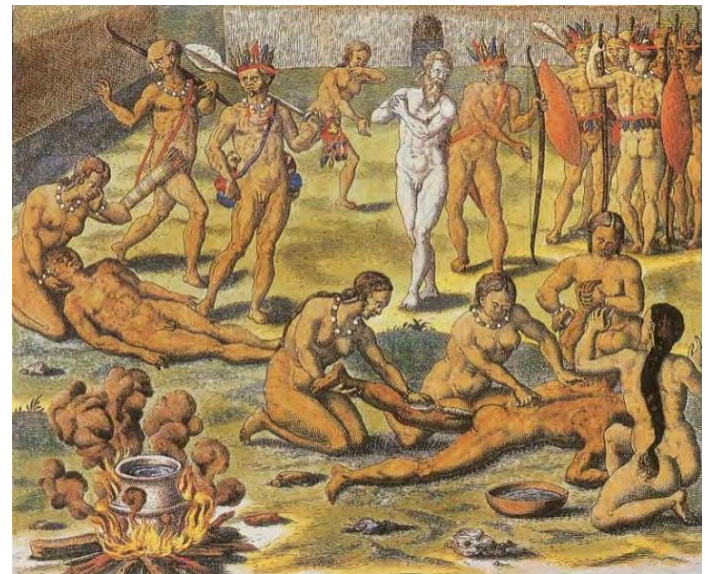

Figura 20 Theodore de Bry

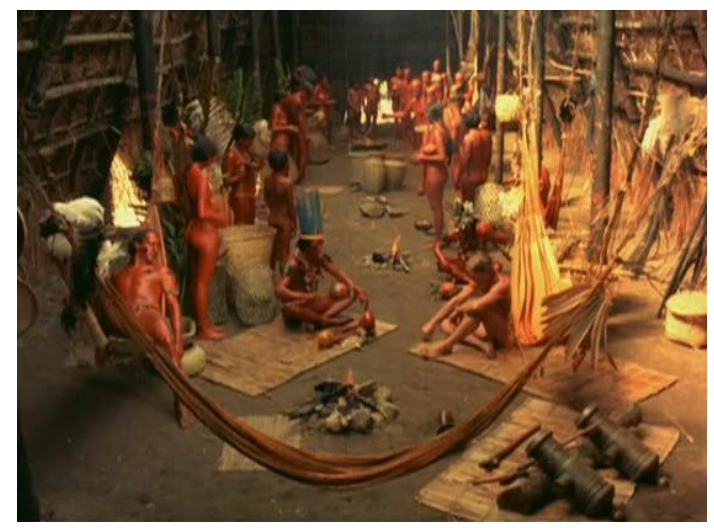

Figura 21 e 22 Cenas do filme Como era Gostoso meu Francês

Os Inconfidentes (Joaquim Pedro de Andrade, 1972) que narra a Inconfidência Mineira a partir dos Autos da Devassa e dos versos de Cecília Meirelles.

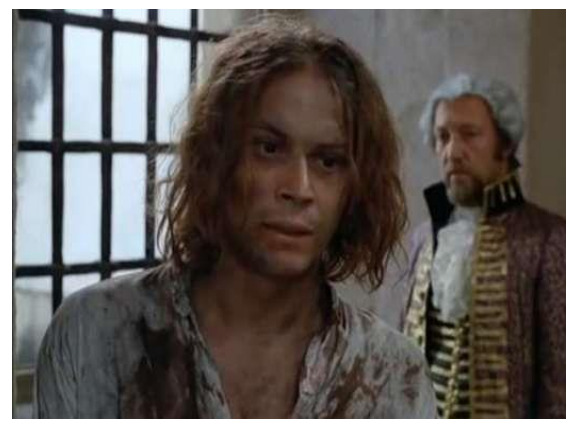

Figura 23

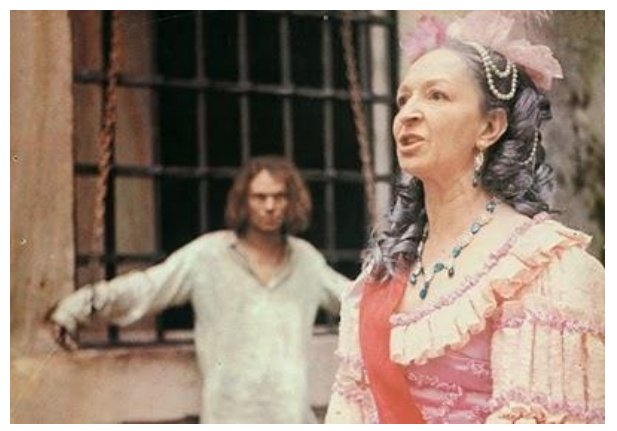

Figura 24 cenas do filme Os Inconfidentes 
Os Inconfidentes mistura os relatos dos Autos da Devassa contra os acusados de traição à corte portuguesa, poesias de integrantes da conjugação mineira e textos de Cecília Meireles para traçar um retrato ambíguo dos líderes do movimento que nunca chegou à ação, sufocado pelos dominadores em 1798. Com ironia, Joaquim Pedro mostra como destacados cidadãos da sociedade, revoltados contra a derrama (taxação compulsória) imposta aos empresários e proprietários de jazidas em Minas Gerais, passam de inflamados sediciosos a covardes que abjuram de suas ideias depois de presos pela autoridade portuguesa.

O filme de Andrade passeia confortavelmente entre o épico e o patético, com a assinatura transgressora do diretor que, mesmo com figurinos que buscavam seguir a época em questão sem maiores alegorias, não foram suficientes para conter a crítica que afirmava, na época do lançamento, que o público esperava mais de um filme histórico. Peixoto cita as falas de Ely Azeredo.

Ely Azeredo (1972) comenta que o diretor Joaquim Pedro de Andrade "tinha todo o direito de fazer um filme desencantado, mas certamente teria sido mais feliz[...] se houvesse levado em conta - sem trair suas ideias - que o público espera do filme histórico um mínimo de aparato espetacular (PEIXOTO, 2015, p.66)

Crítica que se reproduz, infelizmente, ainda nos dias de hoje quando se espera do cinema mais espetáculo que conteúdo.

São Bernardo (Leon Hirzman, 1972), adaptação do romance homônimo de Graciliano Ramos, o filme é tratado por Peixoto como "[...] quase uma transposição de materialidade do papel para a película", devido às fidelidades estético-narrativas do mesmo.

Em comum as obras de Ramos e Hirszman têm a secura, o rigor e contenção ao narrar este drama político-psicológico, numa fidelidade ao "realismo" não muito comum ao Cinema Novo.

Hirszman usa a riqueza da dramaturgia de Ramos como seu fio condutor e a arte e o figurino de Ripper seguem segurando pela mão a condução de seu diretor.

A imagem que escolhemos na internet para representar a delicadeza e a fidelidade de Ripper foi, coincidentemente uma das escolhidas por Peixoto, sendo que ele conseguiu captar quatro frames do filme, reproduzidos aqui. 

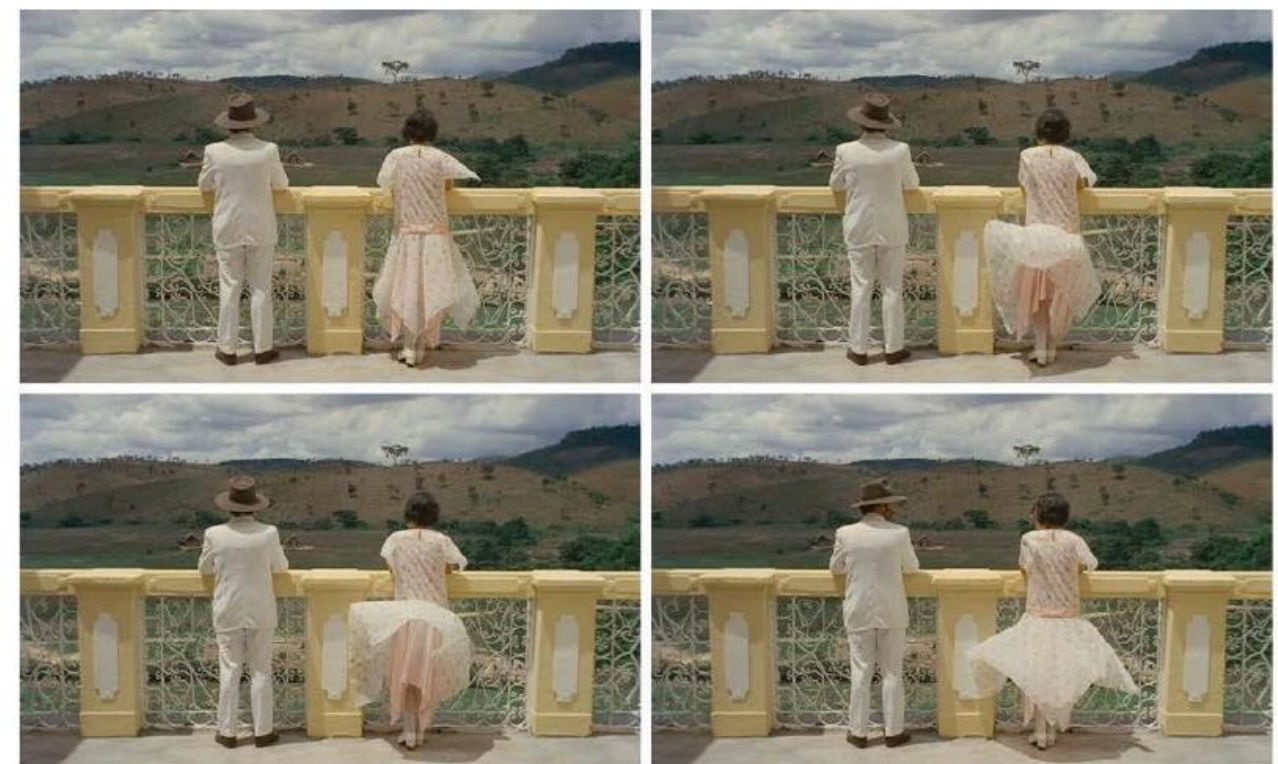

IMAGEM 2 | O vento sopra a saia de Madalena (sequência de frames de São Bernardo).

Figura 25 Cena do filme São Bernardo ${ }^{10}$

Xica da Silva (Cacá Diegues, 1976), baseado no romance "Memórias do Distrito de Diamantina", de João Felício dos Santos o filme, conta a trajetória de Chica da Silva, que mesmo sendo uma escrava, tornou-se um mito dos mais famosos na história brasileira. Ela veio a tornar-se a primeira dama negra de que se tem conhecimento no Brasil e, no filme de Diegues, ao mesmo tempo em que brinca ao utilizar e ostentar os luxos europeus acaba por zombar e questionar toda uma instituição colonial. O todo da plástica do filme de Diegues (a começar pela música), firmemente apoiada no cenário e figurino corroboram com o filme histórico clássico e apoteótico, sem deixar de carregar consigo o alegórico e o burlesco, que ecoam a veia original do Cinema Novo.

\footnotetext{
${ }^{16}$ PEIXOTO, P.80
} 


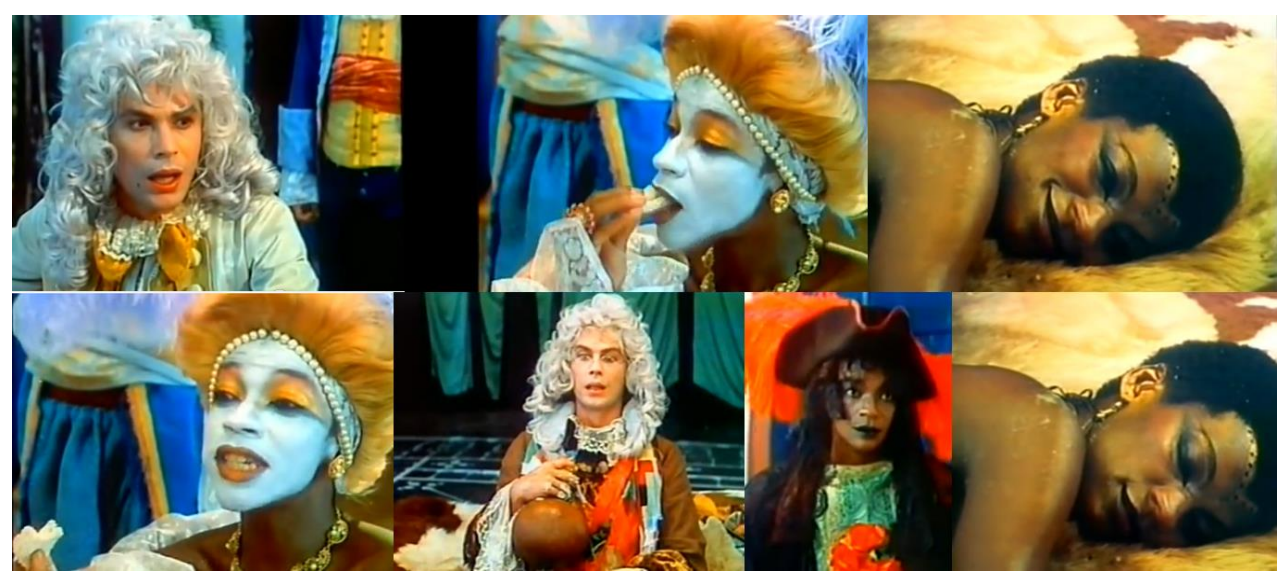

Figura 26 - cenas do filme Xica da Silva

\section{4 - Cinema da Retomada}

$S$ abemos que a história do cinema brasileiro é formada por ciclos - ou "surtos", como preferiu definir o cineasta e crítico Alex Viany.

Dos míticos anos ainda na era do cinema mudo, quando os filmes sobre crimes hediondos e os chamados "cantantes" (musicais com cantores ao vivo, situados atrás da tela) teriam caído no gosto do povo; passando pelos ciclos regionais dos anos 1920 e 1930; pelas tentativas de se estabelecer estúdios nos moldes hollywoodianos como Cinédia, Vera Cruz e Maristela; pelo estrondo das chanchadas musicais da Atlântida nos anos 1950 pelo vigor estético do Cinema Novo, nos anos 1960, e pelos anos da Embrafilme, a partir de 1964, a produção nacional sempre viveu altos e baixos. A fase da Embrafilme uma das mais complexas e interessantes, terminou com um decreto assinado pelo presidente Fernando Collor, em março de 1990.

A partir daí, teve início um lento processo de recuperação que acabou sendo batizado de "Retomada". Pouco a pouco, a produção de longas-metragens foi se recuperando e se revitalizando. Veteranos voltaram a filmar novas gerações se sucederam, novas formas de financiamento foram criadas, veio a digitalização e a revolução da internet.
Em 2015, completam-se 20 anos daquele que foi considerado o ponto inicial desse processo de revitalização, quando chegaram aos cinemas Terra estrangeira, de Walter Salles e Daniela Thomas, primeira produção dessa nova fase a chamar atenção do mundo para o que se passava no Brasil, e Carlota Joaquina, de Carla Camurati, que iniciou um processo de reconciliação do cinema brasileiro com seu próprio público.

Nas próximas páginas, você vai encontrar os filmes e acontecimentos mais marcantes desses últimos 20 anos. Um artigo de José Carlos Avellar abre os trabalhos. Em seguida, para facilitar a organização das informações, dividimos a Retomada em três fases.

A primeira começa em 1995 e vai até 2002, quando estreia Cidade de Deus, um dos grandes fenômenos dessa nova história.

A segunda fase tem início com o "ano histórico" de 2003, quando a produção nacional alcançou mais de $21 \%$ de participação de mercado, e termina com o lançamento de outro grande fenômeno, o primeiro Tropa de elite.

E terceira fase começa com a entrada em operação do Fundo Setorial do Audiovisual, em 2008, e termina com..

Bem, dessa vez a gente espera que não tenha fim.

Paulo Sergio Almeida, revista Filme B

Em 1989 ao realizar as primeiras eleições diretas, depois de 25 anos de ditadura, foi eleito o primeiro presidente brasileiro da era da redemocratização, Fernando Collor de Mello tomou posse como em 1990, em meio a uma grande crise política.

Além da crise política e financeira, os anos 1990 assinaram o obituário do cinema brasileiro. Pelas mãos do mesmo presidente Çollor de Mello, os principais 
órgãos de fomento e distribuição do cinema nacional, como a Embrafilme (Empresa Brasileira de Filmes, 1969-1990), o Concine (Conselho Nacional de Cinema 1976-1990) e a Fundação do Cinema Brasileiro (1988-1990) foram extintos (durante cerca de 20 anos, a Embrafilme e o Concine formaram a base da indústria cinematográfica no país). Os anos 80 haviam sido os melhores para a indústria nacional de cinema, entre 1981 e 1986, os cinemas brasileiros contavam com, pelo menos, 75 estreias nacionais por ano ${ }^{17}$

Com isso, o número de salas de exibição e de espectadores foi reduzido drasticamente e milhares de profissionais da área ficaram sem trabalho, migraram para a televisão e a publicidade ou deixaram o país.

Em 1991, numa tentativa de compensar a extinção desses dois órgãos (Embrafilme e Concine), o presidente Collor criou a Lei $\mathrm{n}^{\circ} 8.313$, conhecida como Lei Rouanet, que permitia que empresas ou pessoas físicas financiassem projetos culturais de um modo geral. Nesse momento, no entanto, as dificuldades econômicas por que passava o país impediram que a indústria cinematográfica fosse beneficiada pela lei. Como consequência, em 1992, apenas três produções nacionais chegaram ao circuito ${ }^{18}$. Dois anos depois Fernando Collor de Mello foi deposto pelo Congresso Nacional ao ser comprovado seu envolvimento num poderoso esquema de corrupção. Além disso, seu plano econômico, voltado para combater a inflação que atingia a cifra de $80 \%$ ao mês, representou para o país um dos seus piores momentos econômicos de toda a História.

Com a saída de Fernando Collor de Mello, Itamar Franco, o então vicepresidente, assumiu a presidência da República e, entre outras medidas, lançou o Plano de Estabilização Econômica que visava combater a inflação e preparar a economia para a entrada em circulação de uma nova moeda. Nesse processo de recuperação, na área de cultura, o governo aprovou a Lei $n^{\circ} 8.685$, em 1993, conhecida como Lei do Audiovisual, que passou a ser utilizada, muitas vezes, em conjunto com a Lei Rouanet.

\footnotetext{
17 * O ano de 1984 foi o ano com o maior número de lançamentos nacionais em salas de cinema: 108 filmes brasileiros foram estreados nesse ano. (Associação Brasileira das Empresas Exibidoras Cinematográficas Operadoras de Multiplex (Abraplex), www.abraplex.com.br, mercado brasileiro).

${ }^{18}$ Filme B, Database Brasil 2001
} 
RANKING NACIONAL - PRIMEIRA FASE (1995-2002)

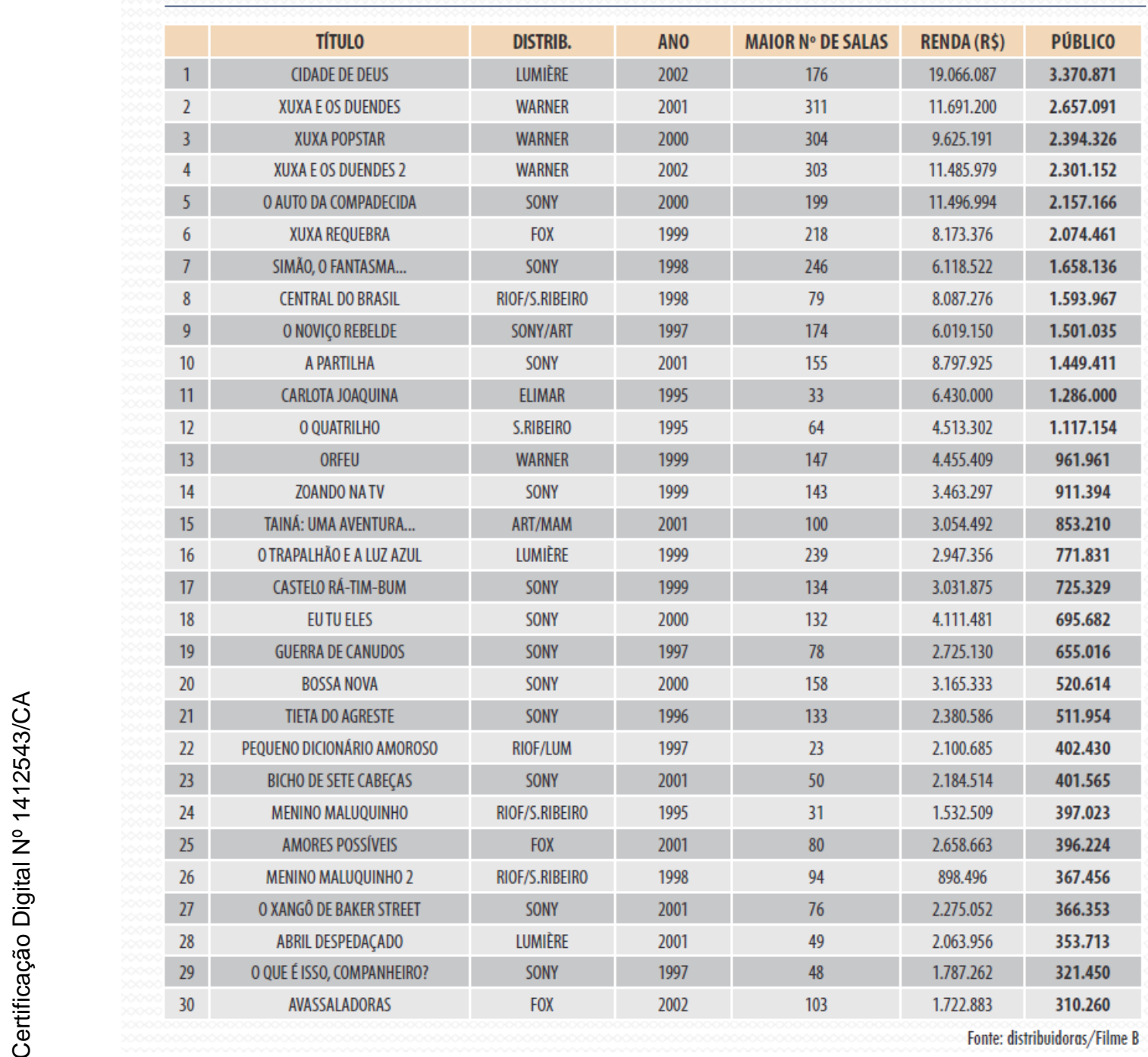

As principais fontes de financiamento do período foram a Lei 8.813/91 (Lei Rouanet) e o artigo $1^{\circ}$ da lei 8.695/93 (Lei do Audiovisual), citadas anteriormente, segundo Marcelo Ikeda. Outro órgão de peso nessa fase foi a RioFilme, criada em 1992 e, durante alguns anos, única distribuidora do cinema nacional.

Carlota Joaquina, a princesa do Brazil, de Carla Camurati, foi lançado no mesmo ano de $O$ Quatrilho, de Fabio Barreto,1995. Ambos são considerados símbolos da "retomada", porém Carlota, teve maior peso; primeiro filme de uma até então atriz, feito em forma de guerrilha, sem dinheiro e com a equipe e o elenco trabalhando praticamente de graça e uma rede de apoios costurada pela produção (para alimentação, passagens aéreas, tecidos etc.) e sem distribuidor (a distribuição foi feita pessoalmente pelas diretora e produtora). Isso ocorreu porque Carlota começou sua produção em 1992, antes da lei do Audiovisual, sem ter 
acesso a certos incentivos dos filmes seguintes e, por isso, demorou tanto a chegar às telas (capítulo 3).

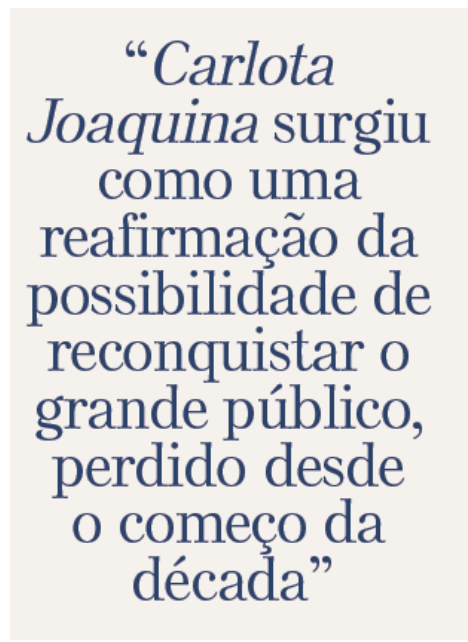

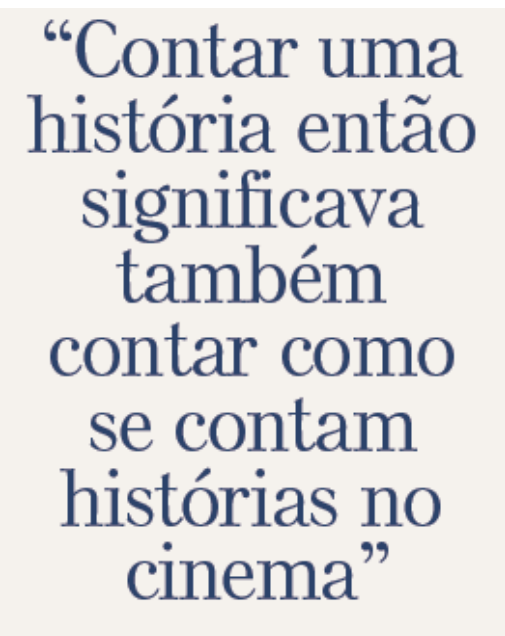

José Carlos Avellar, Revista Filme B

A garra dessa equipe para colocar seu filme na tela foi uma referência e um incentivo para muitos outros profissionais que, há anos sem filmar, ansiavam para voltar aos sets. Somaram-se as indicações ao Oscar de $O$ Quatrilho, Central do Brasil e $O$ que é Isso, Companheiro, que colocaram o cinema brasileiro sob os holofotes do mundo e estimularam a produção nacional e, claro, o orgulho e as expectativas de seus profissionais.

Dois outros filmes de época relevantes desse período foram Guerra de Canudos, de Sérgio Rezende (1997) e Baile Perfumado, de Lírio Ferreira e Paulo Caldas (1997), ambos filmados no sertão nordestino e com enredos que resgatam este viés da cultura brasileira.

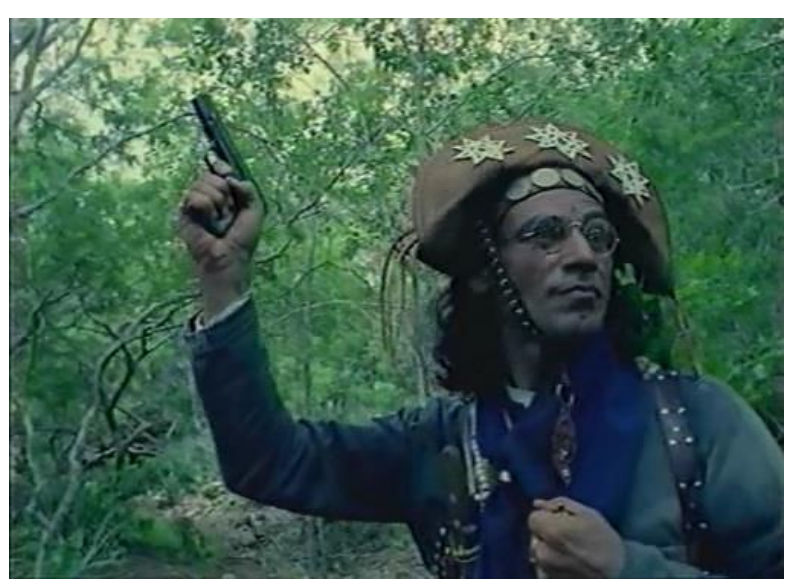

Figura 27 Cena do filme Baile Perfumado 
O surgimento da Globo Filmes ${ }^{19}$, em 1998 e a criação da Ancine (Agência Nacional de Cinema) em 2001criaram a estrutura que sustentou a etapa seguinte, marcada pela solidificação de bases institucionais e daquilo que podemos chamar de blockbuster brasileiro. Não por acaso, esta primeira fase termina com Cidade de Deus, nosso primeiro blockbuster.

\title{
RETOMADA 2 2 FASE - 2003 a 2007
}

\author{
Depois do grande sucesso de Cidade de Deus, a produção nacional viveu \\ alguns anos bastante intensos, com filmes que conseguiram espaço no \\ mercado interno e outros que conquistaram posição de prestígio em \\ festivais internacionais, quando não combinaram as duas coisas. \\ 0 ano de 2003 , até hoje, guarda o recorde em termos de percentual de \\ participação de mercado para filmes brasileiros no período $(21,4 \%)$, graças \\ a um conjunto de títulos que alcançaram bilheterias expressivas como \\ Carandiru, Lisbela e o prisioneiro e Os normais - O filme. \\ Em 2004, duas cinebiografias dramáticas, Cazuza e Olga, surpreenderam \\ com ótimos desempenhos de bilheteria. Em 2005, outra marca \\ importante: 2 Filhos de Francisco tornou-se o primeiro título nacional \\ a liderar o ranking geral do ano, à frente de todas as produções \\ hollywoodianas. \\ O período se encerra com o fenômeno Tropa de elite, de José Padilha, que \\ caiu no mercado pirata meses antes de seu lançamento oficial.
}

Revista Filme B

19 Iniciando suas atividades em 1998, como braço cinematográfico da TV Globo (a maior emissora de televisão aberta do país), a Globo Filmes começou com filmes de profissionais da emissora e, aos poucos foi abrindo seu leque em parcerias com produtoras independentes. Foi o caso dos filmes Cidade de Deus (Fernando Meirelles, 2002) e Carandiru (Hector Babenco, 2003). Todas as 20 maiores bilheterias da Retomada tiveram coprodução da Globo Filmes 
RANKING NACIONAL - SEGUNDA FASE (2003-2007)

\begin{tabular}{|c|c|c|c|c|c|c|}
\hline & TÍTULO & DISTRIB. & ANO & MAIOR N ํ DE SALAS & RENDA (R\$) & PÚBLICO \\
\hline 1 & 2 FILHOS DE FRANCISCO & SONY & 2005 & 329 & 36.728 .278 & 5.319 .677 \\
\hline 2 & CARANDIRU & SONY & 2003 & 298 & 29.623 .481 & 4.693 .853 \\
\hline 3 & SE EUFOSSEVOCE & FOX & 2006 & 197 & 28.916.137 & 3.644 .956 \\
\hline 4 & LISBELA E O PRISIONEIRO & FOX & 2003 & 245 & 19.915.933 & 3.174 .643 \\
\hline 5 & CAZUZA: OTEMPO NÃO PARA & SONY & 2004 & 292 & 21.230 .606 & 3.082 .522 \\
\hline 6 & OLGA & LUMIERE & 2004 & 339 & 20.375 .397 & 3.078 .030 \\
\hline 7 & OS NORMAIS - 0 FILME & LUMIËRE & 2003 & 249 & 19.874 .866 & 2.996 .467 \\
\hline 8 & TROPA DE ELITE & UNIVERSAL & 2007 & 321 & 20.422 .567 & 2.421.295 \\
\hline 9 & MARIA: A MÅE DO FILHO DE DEUS & SONY & 2003 & 303 & 12.842 .085 & 2.332 .873 \\
\hline 10 & SEXO, AMOR E TRAIÇĀOO & FOX & 2004 & 157 & 15.775.132 & 2.219 .423 \\
\hline 11 & XUXA ABRACADABRA & WARNER & 2003 & 307 & 11.677 .129 & 2.214.481 \\
\hline 12 & A GRANDE FAMILLIA - 0 FILME & EUROPA/MAM & 2007 & 262 & 15.482 .240 & 2.035 .576 \\
\hline 13 & DIDI:0 CUPIDO TRAPALHÃO & SONY & 2003 & 147 & 8.984 .535 & 1.758 .579 \\
\hline 14 & DEUSÉ BRASILEERO & SONY & 2003 & 162 & 10.655 .438 & 1.635 .212 \\
\hline 15 & XUXA E OTESOURO DA CIDADE PERDIDA & WARNER & 2004 & 300 & 7.108 .730 & 1.331 .652 \\
\hline 16 & A DONA DA HISTÓRIA & BUENA VISTA & 2004 & 260 & 9.025 .423 & 1.271 .415 \\
\hline 17 & XUXA GËMEAS & FOX & 2006 & 277 & 5.802 .977 & 1.035 .700 \\
\hline 18 & DIDI - O CAÇADOR DE TESOUROS & BUENA VISTA & 2006 & 199 & 6.220 .016 & 1.024.732 \\
\hline 19 & DIDI QUER SER CRIANÇA & SONY & 2004 & 154 & 5.583 .242 & 982.175 \\
\hline 20 & O CASAMENTO DE ROMEU E JULIETA & BUENA VISTA & 2005 & 215 & 7.303 .657 & 969.278 \\
\hline 21 & IRMÄOSDEFÉ & SONY & 2004 & 294 & 5.652 .025 & 966.021 \\
\hline 22 & PRIMO BASILIIO & BUENA VISTA & 2007 & 163 & 6.376 .703 & 838.726 \\
\hline 23 & ACQUARIA & FOX & 2003 & 340 & 4.466 .393 & 837.695 \\
\hline 24 & TAINÁ 2: A AVENTURA CONTINUA & SONY & 2005 & 164 & 4.612 .264 & 788.442 \\
\hline 25 & ZUZU ANGEL & WARNER & 2006 & 173 & 5.789 .238 & 774.318 \\
\hline 26 & O CAVALEIRO DIDI EA PRINCESA LILI & BUENA VISTA & 2006 & 163 & 4.672 .418 & 742.340 \\
\hline 27 & CASSETA \& PLANETA: A TAÇA... & WARNER & 2003 & 274 & 4.346 .394 & 690.709 \\
\hline 28 & OHOMEM QUE COPIAVA & SONY & 2003 & 70 & 4.692 .436 & 664.651 \\
\hline 29 & OCORONEL E O LOBISOMEM & FOX & 2005 & 166 & 4.678.543 & 654.983 \\
\hline 30 & CASSETA \& PLANETA: SEUS PROBLEMAS.... & EUROPA/MAM & 2006 & 180 & 4.262.366 & 596.624 \\
\hline
\end{tabular}

A principal fonte de financiamento do período foi a Lei do Audiovisual, segundo Marcelo Ikeda.

Filmes de época que marcaram o período, todos coproduções com a Globo Filmes, foram Lisbela e o Prisioneiro (Guel Arraes,2003), baseado no romance de Ariano Suassuna e com uma plástica que segue a linha alegórica. E as cinebiografias Cazuza, o Tempo Não Para (Sandra Werneck e Walter Carvalho, 2004) e Olga (Jayme Monjardim, 2004), seguindo uma linha mais realista. 


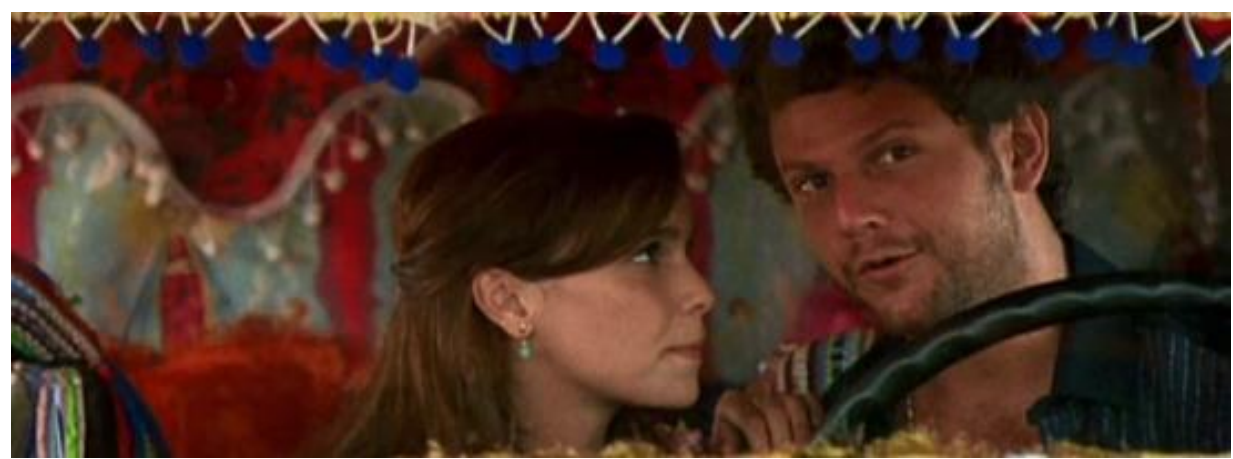

Figura 28 cena do filme Lisbela e o Prisioneiro

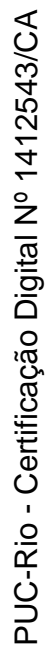

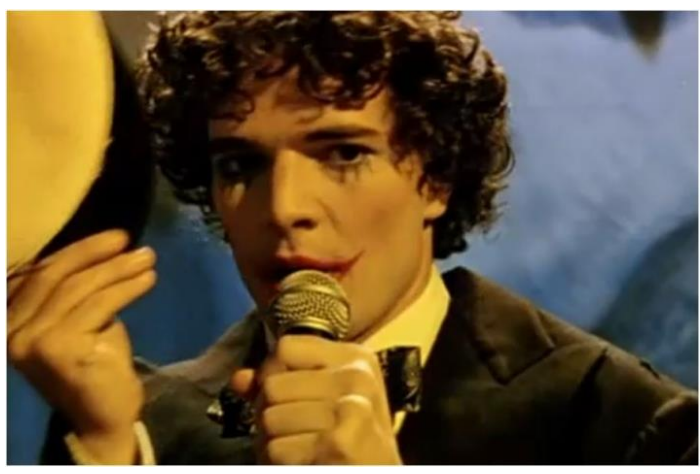

Figura 29 Cena do filme Cazuza

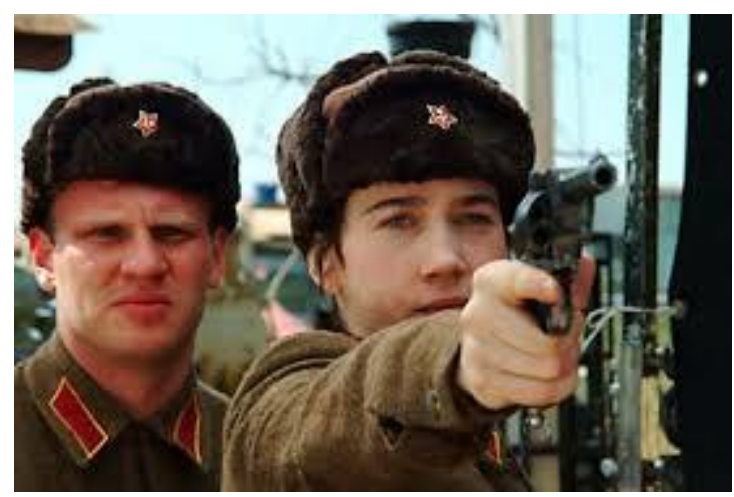

Figura 30 cena do filme Olga 


\title{
RETOMADA 3르 FASE - 2008 a 2015
}

\section{NOVOS MARCOS, NOVOS RUMOS}

\begin{abstract}
A terceira fase da Retomada é marcada, sobretudo, por uma grande transformação nas formas de financiamento do setor com a implementação do Fundo Setorial do Audiovisual, que foi criado em 2006, regulamentado em 2007 e começou a funcionar, efetivamente, a partir de 2008.

$\mathrm{O}$ ano de 2010 se torna outro marco, principalmente devido ao lançamento de Tropa de elite 2, recordista da história do cinema brasileiro (pelo menos do que se tem registro), com público de mais de 11,2 milhões, somado ao sucesso de dois filmes de temática espírita - Nosso lar e Chico Xavier, que juntos venderam mais de 7,4 milhões de ingressos.

A consolidação das franquias, principalmente das comédias, e a aprovação da Lei 12.485/2011, que regulamenta a TV por assinatura e estabelece cotas para a produção independente nos canais estrangeiros, são outras novidades importantes.
\end{abstract}

Revista Filme B

RANKING NACIONAL - TERCEIRA FASE (2008-2015)

\begin{tabular}{|c|c|c|c|c|c|c|}
\hline & TÍTULO & DISTRIB. & ANO & MAIOR N ${ }^{\circ}$ DE SALAS & RENDA (R\$) & PÚBLICO \\
\hline 1 & TROPA DE ELITE 2 & ZAZEN/RIOF & 2010 & 703 & 103.812.200 & 11.204 .815 \\
\hline 2 & SE EU FOSSE VOCE 2 & FOX & 2009 & 309 & 50.543 .885 & 6.137 .345 \\
\hline 3 & DE PERNAS PRO AR 2 & DTF/PARIS & 2012 & 718 & 50.292 .566 & 4.794.658 \\
\hline 4 & MINHA MÃEE UMA PEÇA - O FILME & DTF/PARIS & 2013 & 406 & 49.534 .000 & 4.604.505 \\
\hline 5 & NOSSO LAR & FOX & 2010 & 443 & 36.126 .000 & 4.060 .000 \\
\hline 6 & ATE QUEA SORTE NOS SEPARE 2 & DTF/PARIS & 2013 & 776 & 45.355 .454 & 3.988 .386 \\
\hline 7 & LOUCAS PRA CASAR & DTF/PARIS & 2015 & 605 & 45.878 .600 & 3.776 .390 \\
\hline 8 & DE PERNAS PRO AR & DTF/PARIS & 2011 & 345 & 31.521 .072 & 3.563.723 \\
\hline 9 & ATÉ QUE A SORTE NOS SEPARE & DTF/PARIS & 2012 & 412 & 34.802 .906 & 3.435 .824 \\
\hline 10 & CHICOXAVIER & DTF/SONY & 2010 & 388 & 30.300 .000 & 3.414 .900 \\
\hline 11 & MEU PASSADO ME CONDENA & DTF/PARIS & 2013 & 373 & 34.977 .047 & 3.171 .446 \\
\hline 12 & CILADA.COM & DTF/PARIS & 2011 & 380 & 28.362 .645 & 3.020 .337 \\
\hline 13 & VAI QUE DÁ CERTO & IMAGEM & 2013 & 450 & 29.048 .700 & 2.751 .599 \\
\hline 14 & EAI... COMEU? & DTF/PARIS & 2012 & 512 & 26.230 .694 & 2.601 .265 \\
\hline 15 & MEU PASSADO ME CONDENA 2 & DTF/PARIS & 2015 & 615 & 32.479 .060 & 2.600 .451 \\
\hline 16 & OS PENETRAS & WARNER & 2012 & 316 & 25.485 .175 & 2.544 .324 \\
\hline 17 & A MULHER INVISIVEL & WARNER & 2009 & 221 & 20.498 .576 & 2.353 .136 \\
\hline 18 & O CANDIDATO HONESTO & DTF/PARIS & 2014 & 554 & 25.067 .100 & 2.298 .445 \\
\hline 19 & CARROSSEL - O FLLME & DTF/PARIS & 2015 & 610 & 24.380 .198 & 2.266 .149 \\
\hline 20 & OS NORMAIS 2 & IMAGEM & 2009 & 432 & 18.926.851 & 2.177 .657 \\
\hline 21 & BRUNA SURFISTINHA & IMAGEM & 2011 & 342 & 19.958 .683 & 2.167.189 \\
\hline 22 & MEU NOME NÃO E JOHNNY & DTF/SONY & 2008 & 171 & 18.365.978 & 2.115.331 \\
\hline 23 & OS CARAS DE PAU EM... & IMAGEM & 2014 & 552 & 22.836 .894 & 1.914 .406 \\
\hline 24 & ASSALTO AO BANCO CENTRAL & FOX & 2011 & 305 & 18.642 .708 & 1.878.227 \\
\hline 25 & DIVĀ & DOWNTOWN & 2009 & 137 & 16.480 .499 & 1.851 .341 \\
\hline 26 & OS HOMENS SÃOO DE MARTE... & DTF/PARIS & 2014 & 465 & 21.630 .100 & 1.806 .937 \\
\hline 27 & S.OS. MULHERES AO MAR & DISNEY & 2014 & 423 & 20.834 .125 & 1.788 .813 \\
\hline 28 & SOMOSTÃO JOVENS & IMAGEM/FOX & 2013 & 550 & 18.283.134 & 1.723 .923 \\
\hline 29 & CRÓ & DTF/PARIS & 2013 & 460 & 18.715 .255 & 1.720 .980 \\
\hline 30 & FAROESTE CABOCLO & EUROPA & 2013 & 464 & 16.025 .298 & 1.524.867 \\
\hline
\end{tabular}

Fonte: distribuidoras/Filme B

A principal fonte de financiamento do período foi o Fundo Setorial do Audiovisual (FSA), criado pela lei 11.437/06 e regulamentado pelo decreto 6.299 de 12 de dezembro de 2007.trazendo uma mudança profunda nas políticas públicas para o audiovisual. O FSA é uma categoria de programação específica do Fundo Nacional de Cultura alimentado pela arrecadação da Condecine 
(Contribuição para o Desenvolvimento da Industria Cinematográfica Nacional) e por receitas de concessões e permissões, principalmente do Fistel Fundo de Fiscalização das telecomunicações). ${ }^{20}$ O FSA já injetou na atividade, e, seis anos, mais de R\$1,1 bilhão. Faz-se pertinente mencionar que neste ano de 2016 as empresas de telefonia entraram na justiça para deixar de contribuir com o Fundo, fato que põe em risco toda a produção nacional a partir de então.

Filmes de época que marcaram o período foram Meu Nome Não é Johnny (Mauro Lima.2008) baseado em um personagem real dos anos 1980 e Faroeste Caboclo (René Sampaio,2013), dramatização da história contada na música homônima de Renato Russo e um dos grandes sucessos do grupo Legião Urbana.

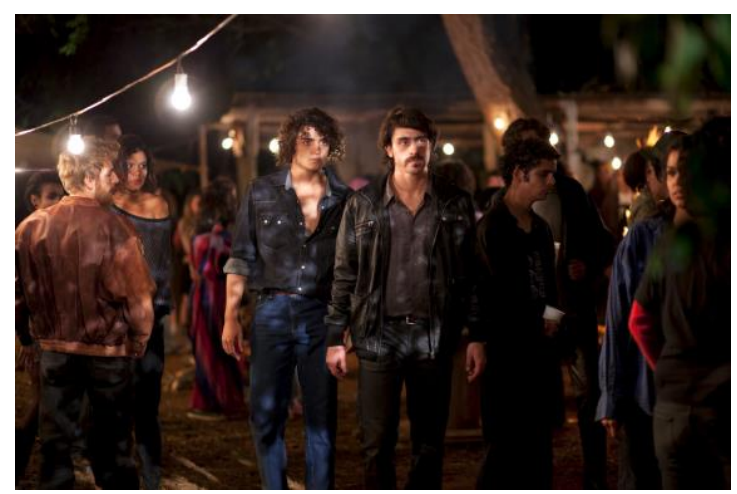

Figura 31 cena do filme Faroeste Caboclo

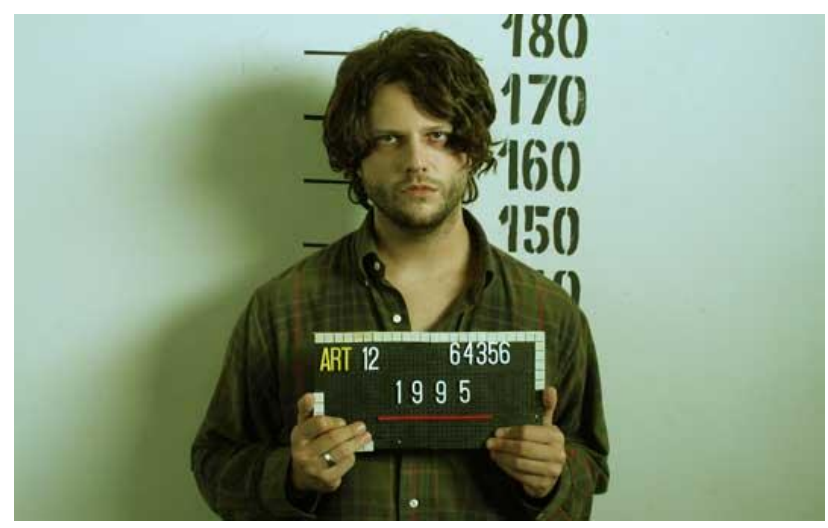

Figura 32 Cena do filme Meu nome Não é Johnny

${ }^{20}$ A Condecine, principal fonte de alimentação do FSA, é gerada a partir da veiculação, licenciamento e distribuição de obras audiovisuais com finalidade comercial. Ou seja:a lógica do FSA é que o dinheiro da própria atividade alimente a atividade. 


\section{3}

\section{Vestindo o Cinema}

Quando um ator está engatinhando no texto, ainda naquela fase de achar caminhos e intenções, podemos dizer com certa dose de humor que ele está nu. $\mathrm{Nu}$, claro, no sentido figurado, mas, de certo modo, também nu fisicamente, porque ainda não sabe com que roupa irá colorir as fantasias que tece em torno do ser imponderável que está gestando no seu íntimo e que tem o nome bem apropriado de personagem. É nessa fase de incertezas dramáticas que a mão salvadora do mágico das roupas aparece para vestir os nus

Hilton Marques

Este capítulo, o eixo temático desta dissertação, é dedicado a descrição dos processos de criação do figurino (estudos de caso) dos três filmes selecionados da chamada "retomada do cinema brasileiro" (introdução / capítulo I): O Quatrilho, Carlota Joaquina, a princesa do Brazil e Guerra de Canudos.

Os filmes foram escolhidos por terem sido as maiores bilheterias de filmes de época do início da retomada, e também por representarem diferentes maneiras de abordar, conceber e produzir um corpo histórico fílmico.

Diferentes orçamentos (que vão dos 600 mil de Carlota aos 6 milhões de Canudos), processos de pesquisa, produção e construção variados e estéticas díspares irão nos ajudar a traçar caminhos diversos, porém possíveis, na realização de um figurino no Brasil.

Carlota é considerado "o símbolo da retomada". Uma mulher (a atriz Carla Camurati) estreando na direção, com um filme sobre uma personagem feminina controversa e malquista, um orçamento inviável para um filme histórico, a dificuldade de apoios (justamente por ter sido o primeiro da retomada) e um modelo de produção quase mambembe são um desafio para sua realização. Com todos esses percalços, o filme, com seu estilo polêmico, faz uma bilheteria impensável para o momento e se torna um marco da cinematografia brasileira.

O Quatrilho seria o "primo rico" de Carlota. Lançado na mesma época do primeiro, apesar de não possuir um orçamento tão alto como Canudos, o filme se valeu das leis de incentivo e dos apoios, articulados por uma das maiores produtoras do Brasil, a LC Barreto. O diretor Fabio Barreto já possuía uma 
carreira consolidada e o estilo realista e comportado de narrar a colônia gaúcha, baseado em um livro local ( $O$ Quatrilho, de José Clemente Pozenato, 1985), angariaram uma legião de apoiadores que foram fundamentais para a qualidade técnica da produção indicada ao Oscar. Até os dias de hoje, esse filme, sem maiores inovações e ousadias estilísticas ainda é o mais lembrado e reverenciado pelo público.

Canudos veio dez anos depois, já com a lei do Audiovisual e o processo da retomada consolidados. Com orçamento de 6 milhões, parceiros como Columbia Pictures, governo da Bahia e patrocinadores de peso como Petrobrás, Eletrobrás, Banco Real, Volkswagen e Telerj. A frente da produção, também uma das maiores produtoras do Brasil, Mariza Leão (Morena filmes) e um diretor com filmes como O Homem da Capa Preta e Lamarca no currículo de filmes sobre personagens de época (aos quais se somariam Mauá e Zuzu Angel, anos depois). A responsável pelo figurino também se distancia das outras duas figurinistas por sua experiência; profissional de carreira na Rede Globo de televisão e com uma longa lista de trabalhos de época no currículo, Elizabeth Filipecki assumiu o figurino de Canudos com muito mais trajetória do que Emilia Duncan e Isabel Paranhos quando assumiram Carlota e $O$ Quatrilho, respectivamente.

Canudos também buscou uma estética realista, como O Quatrilho (característica dos dois diretores), talvez tenha sido aí que tropeçou. Longo demais e ousado de menos, o filme foi o maior orçamento e a menor bilheteria dos três.

Para falar de $O$ Quatrilho, parto da minha experiência pessoal como figurinista e de uma monografia escrita sobre o mesmo, orientada por Maria Augusta Rodrigues.

Para os outros dois filmes usamos quatro entrevistas, com o diretor Sergio Rezende e a figurinista Beth Filipecki do filme Guerra de Canudos e com os figurinistas Emilia Duncan e Marcelo Pies de Carlota Joaquina. As entrevistas foram complementadas com o levantamento de materiais dos filmes e dos realizadores em livros, internet e artigos.

Nosso olhar, aqui, pode-se chamar de um quarto corpo histórico transformado em objeto histórico ao se materializar nessa dissertação. $\mathrm{O}$ primeiro é o fato histórico, o segundo a versão literária do fato, o terceiro a construção cinematográfica e, o quarto esta narrativa interpretativa de tudo isso. 
Diferentemente do habitual, em dissertações acadêmicas, utilizamos trechos das entrevistas (entremeados de comentários e citações) no corpo do texto, bem como imagens ilustrativas do conteúdo das mesmas. Optamos por este formato por considerar uma melhor forma de exemplificar determinadas questões técnicas fundamentais para o entendimento do todo da pesquisa. $\mathrm{O}$ estilo coloquial e as informações de bastidores foram mantidos, pela opção de preservar a intimidade da autora e dos entrevistados com o ambiente cinematográfico.

\subsection{O Quatrilho}

O Quatrilho, de Fabio Barreto, baseado no livro homônimo de José Clemente Pozenato (1985), rodado entre 1994 e 1995, na cidade de Caxias do Sul e regiões vizinhas, na Serra Gaúcha, lançado nos cinemas em 1996 e indicado ao Oscar de melhor filme estrangeiro, se passa entre 1910 e 1930 e tem como personagens imigrantes italianos, originários da região do Vêneto, que se radicaram nessa parte do Rio Grande do Sul constituindo uma colônia, trazendo consigo não só um dialeto próprio como toda uma cultura e hábitos específicos.

Por se tratar de um filme de época e de uma cultura desconhecida, foi necessário um trabalho de pesquisa abrangendo tanto a região de origem como a região de destino: as culturas italiana e brasileira e o que resultou dessa mescla cultural. Esse procedimento integra o processo que chamamos de "reconstrução do corpo histórico".

Esse procedimento durou no total sete meses. Começou no Rio de Janeiro e continuou no Rio Grande do Sul, englobando a pré-produção, produção e pósprodução do filme.

Um trabalho de mão dupla que visava o conhecimento dessa população por parte da nossa equipe e a aceitação desta equipe "estrangeira" por parte deles, para que pudéssemos entrar em suas casas, mexer em seus baús, ouvir suas histórias e, por fim, filmar suas vidas.

Sermos uma equipe de fora (estrangeira), possibilitou um distanciamento e um olhar sobre as questões históricas e culturais sem a interferência de ufanismos ou regionalismos no momento de criação. 
O texto a seguir pretende auxiliar a identificação de semelhanças e diferenças entre os três projetos, como forma de desenhar uma possível linha condutora nos processos de criação e produção dos profissionais dessa época específica.

Aqui, nos limitaremos aos relatos, sem análise do material final por uma questão ética. No decorrer do capítulo, faremos uma análise comparativa dos diferentes processos de pesquisa, elaboração e construção dos figurinos desses três filmes.

\subsubsection{Primeiro passo do processo: o roteiro}

O primeiro passo do figurinista ao ser convidado para um projeto é ler o roteiro, isso vale também para novelas, peças teatrais, balés, shows enfim para qualquer trabalho audiovisual que exija um figurino.

[...] O roteiro de filmagem é dividido em sequências, cada sequência dividida em cenas e, finalmente, as cenas mesmas são construídas a partir de séries de planos, filmados de diversos ângulos. (XAVIER, org. 1983, p.57)

A leitura do roteiro de cinema se dá por etapas. A primeira etapa é, em geral, uma leitura corrida, como em um romance, na qual o profissional vai se inteirar do que se trata o projeto. Isso pode variar um pouco de um profissional para outro e também da sua experiência, mas o objetivo da primeira leitura é localizar o filme no tempo e no espaço.

[...] surge aí uma nova noção do tempo, o tempo fílmico. Não se trata daquele tempo real compreendido pelo fenômeno à medida que desenrola diante da câmera, e sim de um novo tempo, condicionado apenas pela velocidade da percepção e controlado pelo número e pela duração dos elementos separados, selecionados para a representação fílmica da ação. (XAVIER, org. 1983, p.69)

Nessa etapa, tem-se uma primeira visão da linguagem estética utilizada pelo roteirista na elaboração desse texto que, provavelmente, ao chegar às suas mãos já foi aprovado pelo diretor e já possui certas referências quanto a maneira de filmar.

A outra questão que observamos na primeira leitura (aqui está colocada uma forma de trabalho mais pessoal, muitos fazem uma primeira leitura corrida e só começam a marcação depois disso, depende muito da experiência e do método de 
trabalho de cada um), principalmente os figurinistas, são os personagens. Quantos são os personagens principais e os secundários? Qual a primeira imagem que construímos desses personagens? Idade, sexo, profissão, condição econômica etecetera. As cenas com figuração também são marcadas (quantidades de figurantes são extremamente relevantes para a administração da logística)

Após essa primeira leitura "literária" do roteiro, as próximas serão mais técnicas, é o que chamamos de decupagem do roteiro. Nessa etapa é importante quantificar tempos, lugares e personagens e suas interseções. No caso de $O$ Quatrilho há várias épocas, 1910, 1913,1930 e vários locais em cada época, sendo que alguns são os mesmos, só que modificados através do tempo. Isso ocorre também com os personagens, os principais estarão em todo o filme, mas sua curva é modificada através do tempo (e isso inclui o figurino) por questões psicológicas, econômicas e relacionadas às mudanças de hábito e da moda no decorrer dos anos (aqui vale lembrar da flexibilidade do corpo histórico, nosso objeto, no passar do tempo, que não pode passar desapercebida. Em alguns momentos temos a sensação de que o personagem muda tão rápido que nos escapa pelos dedos, isso é um desafio à criatividade e à capacidade de abstração do figurinista). Os secundários estarão em algumas épocas e não em outras. Tudo isso vai gerar (futuramente) o que chamamos de mapa de figurino.

Quando usamos o termo corpo histórico, estamos abrangendo vários elementos individuais (cada personagem, com sua curva de vida, possui um corpo histórico em movimento no tempo) que, somados ao cenário, a fotografia, a dramaturgia, enfim, aos outros elementos fílmicos, irá formar o desenho do produto final: o filme, ele em si, também um corpo histórico, este, porém, estanque, fechado, que assiná-la o exato momento no tempo em que foi produzido. Como um marco. As visões sobre ele (o filme) podem mudar, o objeto em si, não. Passa a ser um objeto histórico naquele momento. O que o torna novamente um corpo histórico em movimento são as suas mudanças no tempo, seus desdobramentos e seus reflexos. Ou seja: podemos considerá-lo um objeto histórico rígido num momento muito fugaz da história, talvez no dia de seu lançamento ou de sua indicação ao Oscar, mas em seguida ele seguirá sua trajetória de objeto mutante e híbrido que, felizmente pode se transformar em coisas ou elementos impensáveis. 
Filmes são objetos e objetos mudam de um dia para o outro: feios ficam bonitos, velhos se tornam modernos, soturnos são risíveis. Acima de tudo, conceitos mudam, portanto, a consciência da efemeridade, da relatividade e da necessidade de flexibilidade são fundamentais para o criador.

Numa segunda leitura do roteiro, se estabelece uma cronologia, define-se o tempo do filme: em quantos dias o filme se passa, se há elipses (passagens de tempo) entre uma cena e outra, etc. Esta fase tem como objetivo um domínio mais específico sobre o material a ser trabalhado logisticamente. Definem-se os dados numéricos do guarda-roupa (quantas trocas cada personagem fará, de quantas peças será composto o figurino destes personagens, a quantidade de roupas necessárias à figuração, quais peças exigem duplicatas).

Paralelamente a esse trabalho técnico, chamado de decupagem, desenvolvese o trabalho de desenho. Iniciam-se os primeiros esboços para o perfil de cada personagem. A participação do diretor e, posteriormente dos atores, faz parte dessa construção.
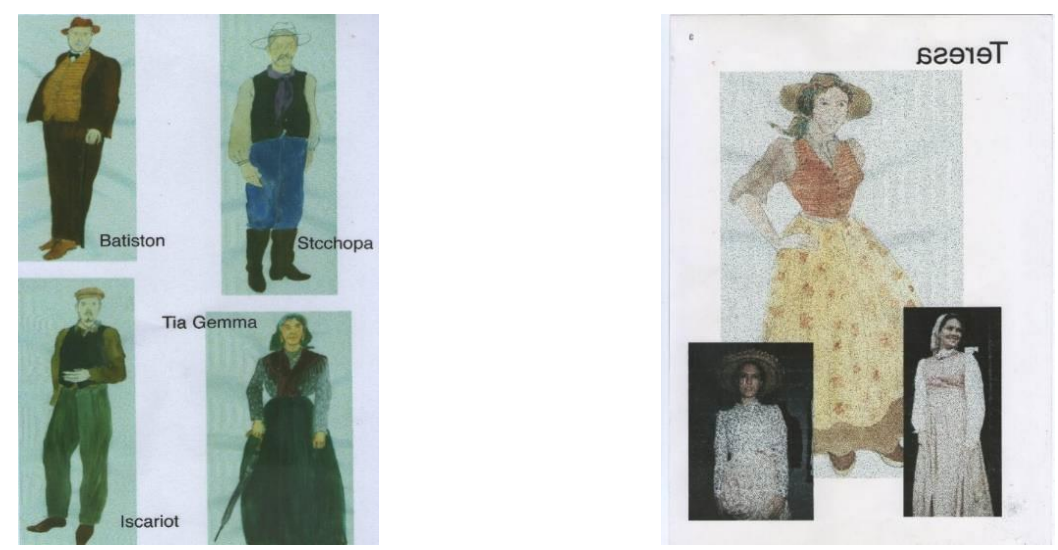

Figura 33 desenho e foto do figurino

No caso de $O$ Quatrilho, após a primeira decupagem do roteiro, foram feitos esboços de cada personagem, ainda no Rio de Janeiro, para tal, além do roteiro foram utilizados o livro Trajes do Imigrante Italiano no Rio Grande do Sul, de Vera Zatera (ano) e fotos de museus da região da colônia trazidas pelo diretor de arte Paulo Flacksman. Uma visita ao consulado italiano no Rio de Janeiro e filmes ambientados no início do século XX (como 1900, de Bernardo Bertolucci, ano) também auxiliaram a pesquisa.

O trabalho no Rio de Janeiro durou pouco mais de um mês, entre leitura e decupagem, pesquisa histórica e desenhos. A partir daí a viagem se fez necessária. 


\subsubsection{A Locação}

Quando o figurinista entra no projeto de um filme, as locações (lugares reais adaptados para ambientar o filme), em geral, já foram escolhidas pelo diretor, junto com o diretor de arte e um produtor de locações.

Qualquer filme, de época ou não pode ser realizado em estúdio (com cenários construídos), em locações ou numa combinação de ambos. O Quatrilho foi todo rodado em locações na serra gaúcha, onde buscou-se reproduzir a mesma região no início do século XX. A Caxias do Sul do início do século, por exemplo, foi filmada numa pequena cidade da serra, Antônio Prado

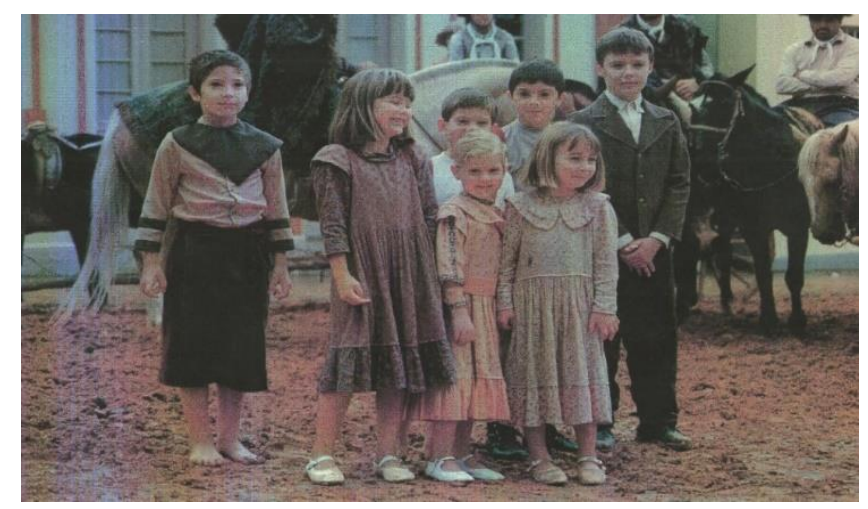

Figura 34 foto de cena

Foi necessário cobrir as ruas de paralelepípedo com terra e retirar toda a fiação elétrica suspensa para simular 1910.

Nem sempre as locações escolhidas são na região onde se passa a história (o filme Floresta das Esmeraldas, de John Boorman, teve cenas rodadas em Parati como se fosse a floresta amazônica).

\subsubsection{A pesquisa de Campo}

Após a etapa inicial no Rio de Janeiro, a equipe de figurino seguiu para o Rio Grande do Sul. A produção foi sediada em Caxias, mas a pesquisa se deu em várias cidades da colônia. Os colonos valorizam a memória e as origens e a região possui vários museus, com arquivos de fotos, acervos de objetos e roupas. 
A pesquisa de campo nas casas dos colonos se fez necessária para complementar e enriquecer com informações mais pessoais a pesquisa histórica. Baús de roupas e fotografias ajudaram a reconstituir peças como roupas de baixo, que não aparecem em fotos.

Muitos objetos utilizados no filme são originais ou réplicas de peças de museu ou acervos pessoais.

A equipe de figurino dividiu-se entre a pesquisa histórica em museus e em campo e a pesquisa de materiais. Foi necessário um levantamento dos materiais disponíveis no mercado dentre tecidos, aviamentos, rendas, enfeites, etc. Foram recolhidas amostras, catalogadas com metragem e preço, que posteriormente seriam adaptadas aos desenhos das roupas.

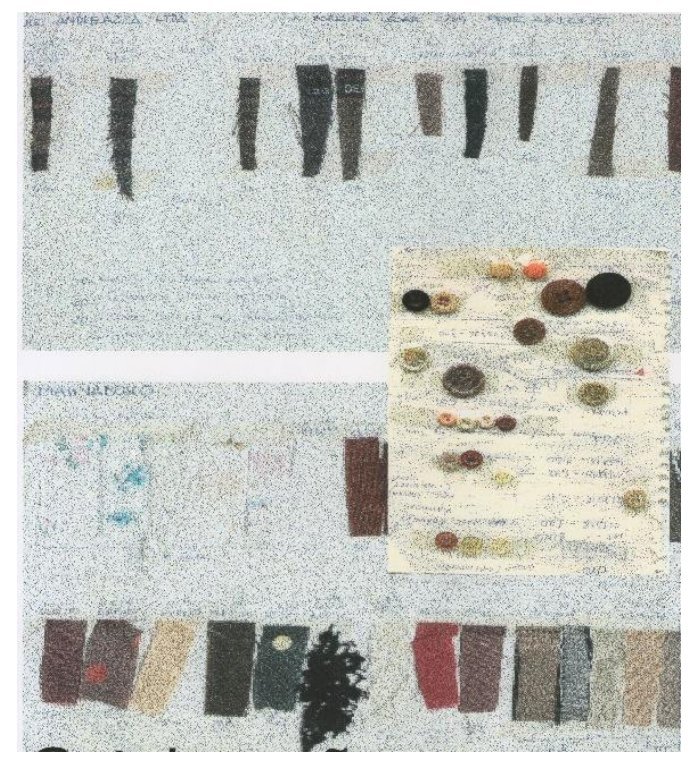

Figura 35 Catalogação de materiais

Nesta fase do trabalho a atenção para detalhes como tipos de costura ou acabamento, bainhas e abotoamentos não podem passar desapercebidos.

O filme deve apoio da Associação comercial de Caxias do Sul, característica dos filmes da retomada, apoiados pela Lei do Audiovisual. Cada lojista entrava com uma cota que podia ser retirada em mercadoria no seu estabelecimento. Devido a isso, o trabalho de levantamento de materiais e valores de cada loja teve que ser minucioso para que conseguíssemos viabilizar nosso figurino com as cotas de doação. Esse apoio foi fundamental para a construção de um figurino numeroso e complexo sem grande orçamento. Ele veio de lojas de tecido, fábricas de sapatos e chapéus, associações e pessoas físicas que compraram cotas do filme 
através da CVM (Comissão de valores mobiliários) e, posteriormente, participaram dos lucros de bilheteria. Alternativa criada durante a retomada para substituir os órgãos de financiamento extintos durante o governo Collor. Este projeto foi feito em condições peculiares de produção que permitiram sete meses de trabalho, mais de setecentos metros de tecido, quatrocentos sapatos, além de chapéus, lenços, bolsas e demais acessórios. Isso dentro de um orçamento que poderia se chamar de modesto para os dias de hoje. Um modo de produção semelhante pode ser observado em outros filmes do mesmo período.

\subsubsection{A pesquisa de materiais}

Pesquisando os materiais da época descobrimos que os tecidos utilizados eram pesados e grosseiros, contribuindo para o mal acabamento das roupas. Seria muito desconforto para os atores vestir esses materiais em pleno verão (período das filmagens). A solução encontrada no mercado foram flanelas (para substituir as lãs), mais leves e com padronagens muito semelhantes aos tecidos da época, principalmente depois de envelhecidas. Os linhões e o brim também foram utilizados por seu aspecto rústico e pela facilidade de envelhecimento (por serem fibras naturais).

Essa foi uma preocupação presente, utilizar tecidos e aviamentos não sintéticos para possibilitar o melhor tingimento e envelhecimento das peças.

\subsubsection{A Pesquisa de Hábitos e Costumes}

As padronagens mais frequentes eram listras e quadriculados, havendo também, em menor número, estampas florais miúdas. 


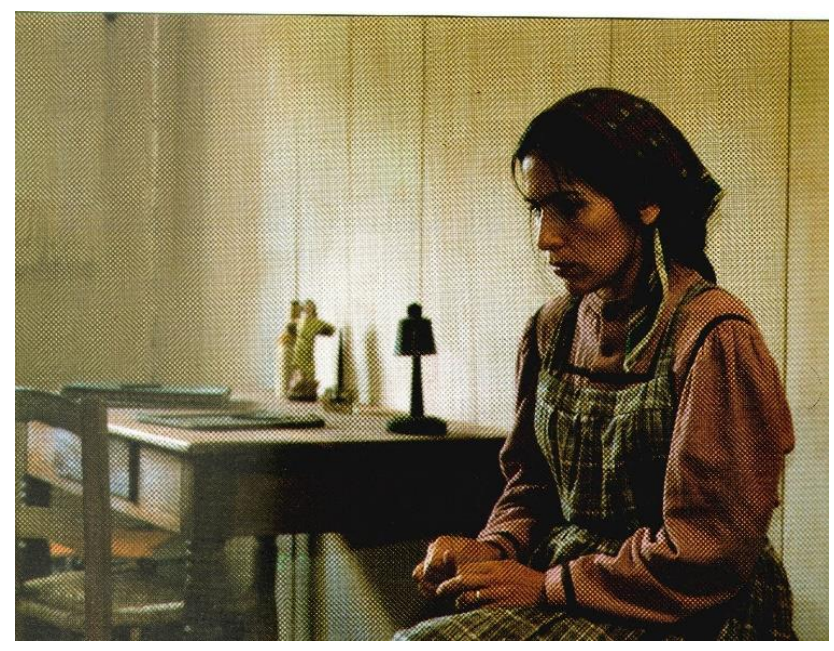

Figura 36 cena do filme

As listras, na época, eram muito usadas na confecção dos tecidos mais pesados e simples, escolhidos pelos colonos pela durabilidade e pela resistência ao frio, tanto nas montanhas do Vêneto como no inverno gaúcho. No acabamento apliques como o guipir, as gregas, sianinhas e rendas podiam aparecer, bem como as dobras e pregas (chamadas de tomas), muito usadas nas barras das saias.

As roupas de baixo podiam ser adornadas com bordado inglês, rendas ou pregas (mas isso era raro). As rendas eram aplicadas sobre o tecido, nunca havendo transparências.

As roupas eram extremamente recatadas, sempre fechadas até o pescoço e os pulsos, com comprimento até os tornozelos, não havia decotes e não eram comuns roupas justas que valorizassem o corpo feminino. A gravidez era disfarçada com roupas largas e as grávidas proibidas de entrar nas igrejas.

Em casa eram usados chinelos de tecido ou couro e no trabalho tamancos de madeira, chancas (botinas de couro com solado de madeira, usados durante o inverno) ou dálmetes (calçado todo em madeira, semelhante aos tamancos holandeses, talvez uma influência das colônias alemãs). 


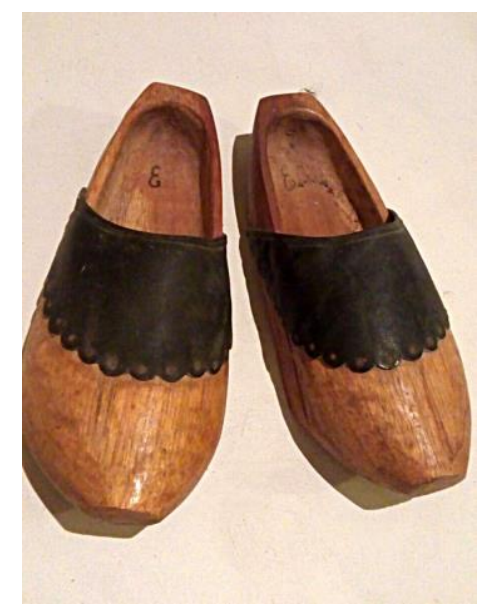

Figura 37 dálmetes

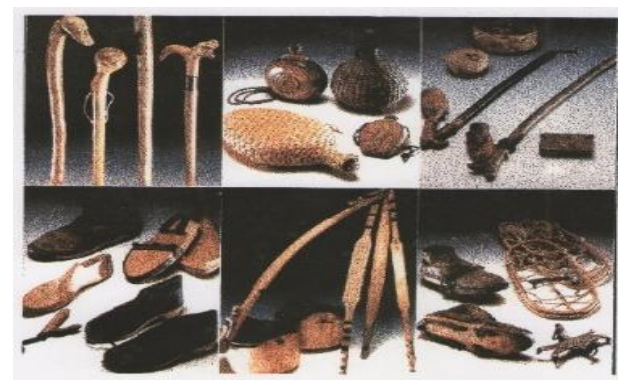

bastões de pastores,cantís e cacchimbos. sapatos,"porta secchi e raquetes para neve.

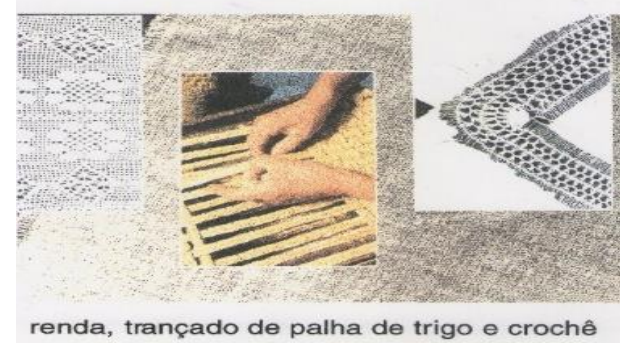

Figura 38 objetos e artesanato

Era comum as crianças e os bebês levarem pendurada ao pescoço uma noz moscada, para trazer alegria e espantar as doenças.

No trabalho diário as mulheres usavam o lenço na cabeça e o avental. As mais tradicionais os usavam mesmo nas festas, para as quais possuíam peças especiais, acompanhadas do lenço estampado cruzado no peito.

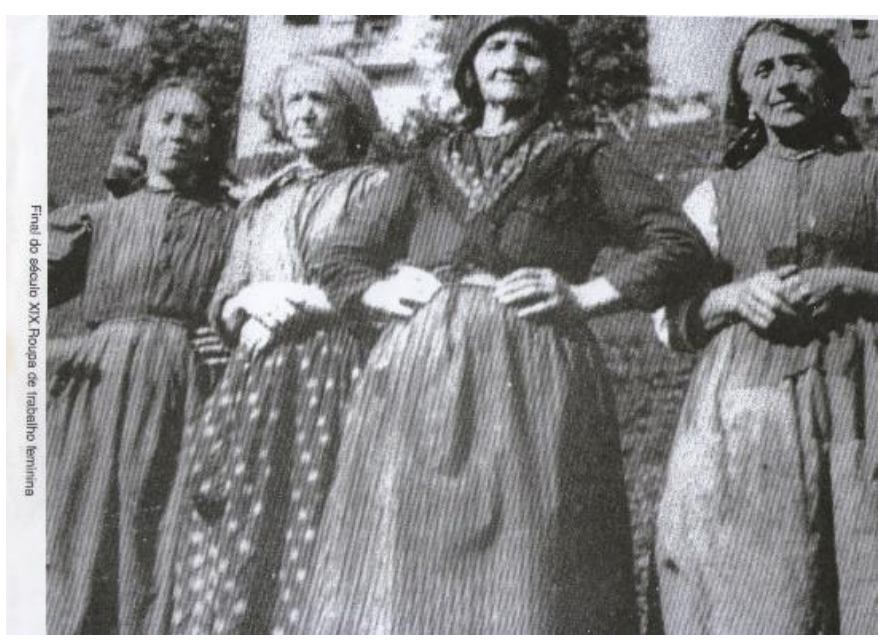

Figura 39 - Foto da época

Outra peça festiva era o fichu (espécie de pelerine na mesma trama da blusa usada como acessório). O chapéu de palha de trigo era usado por homens e 
mulheres que o trançavam nos momentos de folga do mesmo material eram feitas bolsas (sportas).

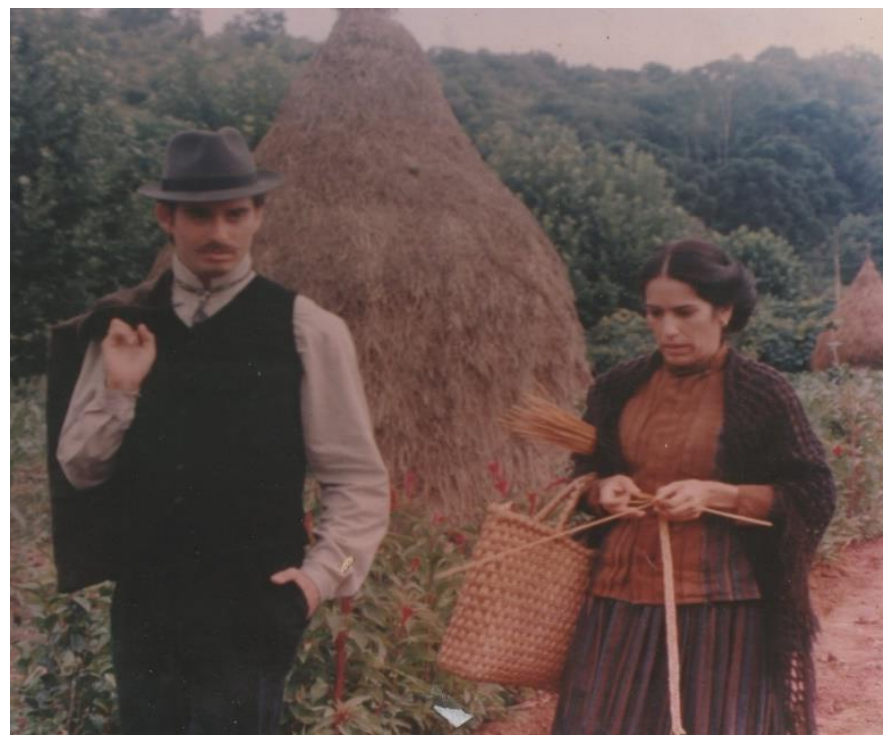

Figura 40 - cena do filme

\subsubsection{A Fabricação dos Figurinos}

A oficina de $O$ Quatrilho foi montada em Caxias do Sul num local cedido pela prefeitura que é a réplica da Caxias do final do século XIX, onde é realizada a Festa da uva. Cada casa comportou um setor da produção. Ao figurino coube três casas, uma para o guarda roupa da figuração, uma para guarda roupa e sala de provas do elenco principal e a terceira para uma grande oficina. Havia, também, uma lavanderia e uma área descoberta para tingimento e envelhecimento.

A equipe era composta de uma figurinista principal e uma figurinista assistente (as únicas vindas do Rio de Janeiro), uma mestra de costura, quatro costureiras, duas auxiliares de envelhecimento e tingimento, duas estagiárias e uma produtora de rua. Para trabalhos especiais foram contratados uma chapeleira, alfaiates e sapateiros. Nesta oficina os desenhos originais eram transformados em desenhos técnicos e entregues a mestre de costura para virarem moldes de papel utilizados para cortar os tecidos definitivos. No caso de indumentárias com modelagem mais complexa (como alguns vestidos de Teresa, personagem de 
Patrícia Pilar) era feito um protótipo em tecido mais barato e só depois de provas no corpo da atriz seria passado para o tecido definitivo.

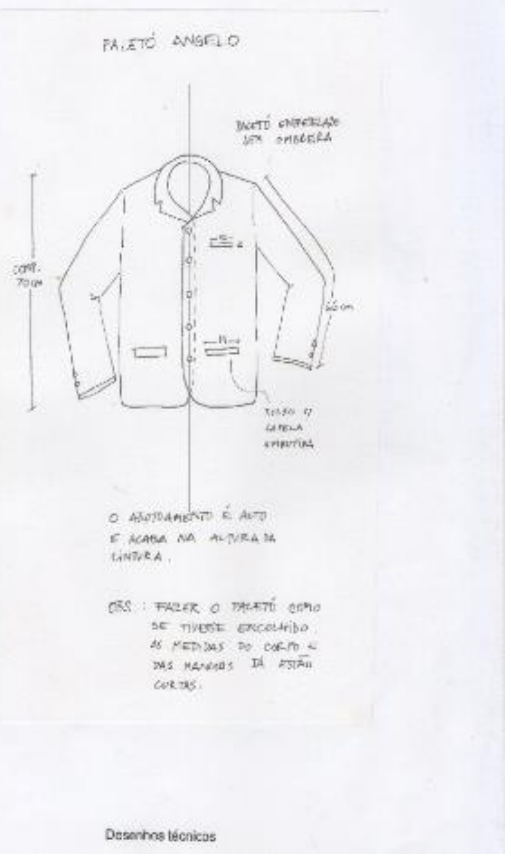

Figura 41 - desenho de modelagem

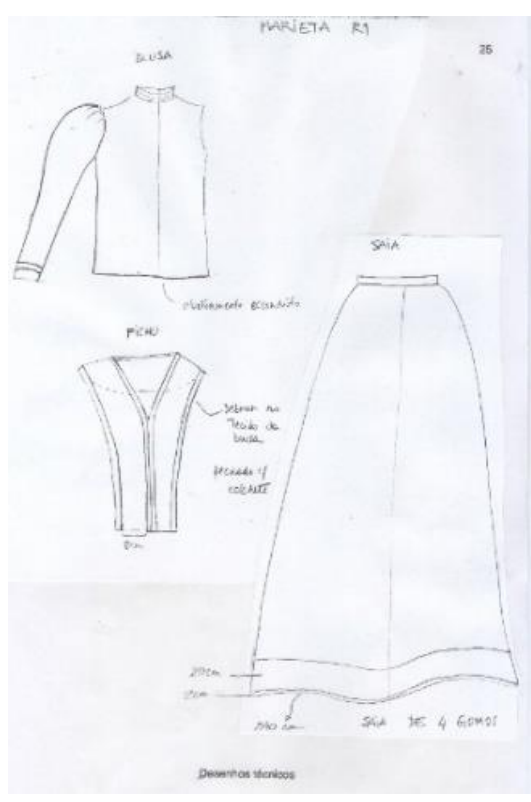

Figura 42 - desenho de modelagem
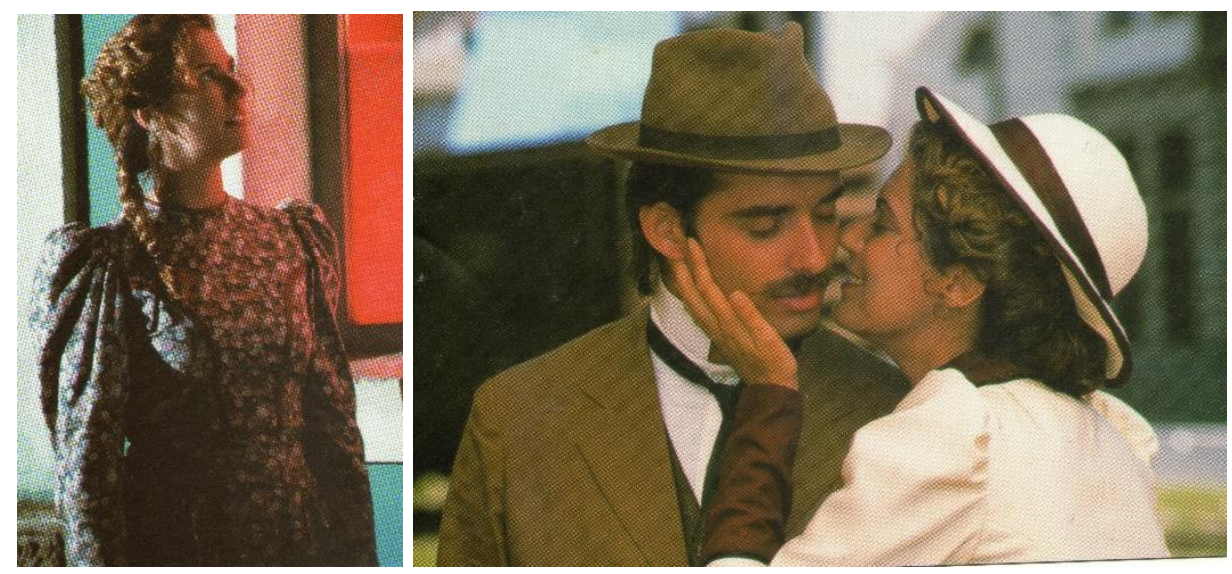

Figura 43 - Cenas do filme

\subsubsection{O Tempo e o Espaço Históricos}

\section{Na Itália}

No final do século XIX houve uma grande emigração dos habitantes do norte da Itália para vários países. O norte italiano vivia, então, uma situação 
socioeconômica extremamente precária. A ausência de novos empregos somada a competição estrangeira e a degradação das pequenas planícies dos vales alpinos, cujas culturas definhavam gradativamente caracterizavam uma séria crise.

As famílias da região, normalmente compostas de cinco elementos, eram divididas em dois tipos: contadinos e operários. Os primeiros eram capazes de sobreviver da cultura da própria terra ou do artesanato, enquanto os outros, por falta de recursos, mandavam um ou mais filhos à cidade em busca de emprego.

Na região do Trentino, só $7 \%$ da população vivia em ambiente citadino, enquanto os $93 \%$ restantes eram grupos agrários que viviam no interior. Essa maioria, de pequena e média burguesia, morava em comunidades dedicadas ao comercio, às profissões industriais e ao artesanato. A atividade agropastoril alpina era pequena, dedicando-se a bovinos, equinos, ovelhas e cabras. A cultura das colinas era voltada às vinhas e à criação do bicho da seda. Sofrendo de moléstias graves e sob ventos frios intensos, as videiras e as amoreiras foram diminuindo sua produtividade e qualidade, desestabilizando, assim, a base econômica daquela região a partir de 1850 .

Com a desqualificação de seus produtos e a concorrência de um mercado competitivo cada vez mais modernizado, proveniente de outros centros europeus, o norte da Itália entrou em crise. A indústria de tecidos sofreu a pressão tecnológica da Inglaterra, com produtos mais baratos e de melhor qualidade, culminando no fechamento das tecelagens do Trentino e do Veneto. Começaram, assim, as emigrações temporárias para regiões vizinhas.

Para completar as dificuldades já existentes, uma inundação do rio Ágide, em 1882, devastou completamente as regiões trentina e veneta, carregando consigo construções, moinhos, serrarias, etc. e deixando para trás mortos, viúvas e miséria.

A limitação de terrenos cultiváveis, a falta de recursos econômicos alternativos e a falência da já fragilizada industrialização foram os fatores determinantes do êxodo italiano para os países da América e Austrália. Todo o sistema sócio econômico entre Veneza e o Trieste despencou.

Formaram-se filas nas listas de espera dos vapores, que levariam os italianos para fora do país. Era 1870, na América via-se a promessa de vida nova, sem impostos e senhores, novo mercado de trabalho, terra própria. O fenômeno emigratório transoceânico teve início. No final do século XIX os países da 
América mais visados pelos emigrantes italianos eram Argentina, EUA, Guatemala e Brasil.

A moda das cidades, influenciada pela modernização da indústria têxtil, não atinge diretamente os camponeses do norte da Itália e nem os emigrantes que, no final no século XIX, chegam ao Rio Grande do Sul. Seus trajes são simples, trajes de trabalho. Seu principal aspecto é a tradição não a renovação. Tendo como característica sempre a utilidade, são roupas duráveis, de quem não pode dispensálas facilmente. Eram, na maioria, duas indumentárias; a chamada de domingo, a roupa mais nova usada na missa e a roupa de trabalho, que foi no passado uma roupa de domingo, porém já gasta e remendada.

Em 1850 o homem alpino usa o traje tradicional: um sapato forte, meias de algodão ou faixas enroladas até o joelho, por vezes, um casaco longo até os quadris. Embaixo do casaco uma camisa simples sem gola, de algodão ou linho feito em casa. Sobre a cabeça um chapéu de abas largas. A calça longa é presa por um cinto largo, sem uso de presilhas. A mulher veste saia rodada de lã com avental de algodão, ambos escuros, com tramas e poucas cores. $\mathrm{O}$ corpete, de tecido diverso da saia, de lã ou algodão, é costurado a ela e sempre sem mangas. A blusa por debaixo do corpete é de manga longa e branca. Sobre o peito, a campesina italiana usa um lenço colorido e com franjas, atravessado e preso na cintura por $\mathrm{m}$ avental. $\mathrm{Na}$ cabeça um lenço, amarrado sob o queixo ou na nuca. Os sapatos têm solados de madeira e os únicos acessórios são brincos de ouro e a aliança, quando casada.

Quando os italianos vieram para o Brasil, trouxeram consigo suas características de grupo social e racial, preservaram seus usos e costumes, quase não se miscigenaram e conservaram sua maneira de vestir por logo tempo, com pequenas modificações necessárias ao novo território.

\section{No Brasil}

O governo brasileiro, ao fazer contratos com agentes em portos europeus no final do século XIX, queria em primeiro lugar povoar as terras do Sul, e oferecia aos imigrantes europeus condições de conforto (nem sempre factíveis) para atraílos.

A proposta do governo era povoar regiões montanhosas, frias e férteis para o plantio de feijão, milho, café, arroz, cana de açúcar, cevada, beterraba, uva e 
amoreiras (para criação do bicho da seda). Essas regiões se encontravam em São Paulo, Paraná, Santa Catarina e Rio Grande do Sul. No Rio Grande do Sul as terras destinadas aos emigrantes foram as da zona da Encosta Superior do Planalto, região entre os vales do Rio do Caí e do Rio das Antas e limitada ao norte pelos Campos de Cima da Serra e ao sul pelas colônias alemãs. Essa região foi organizada e destinada ao assentamento dos imigrantes italianos a partir de 24 de maio de 1870. No entanto, o povoamento da região iniciou-se, na verdade, na Colônia de Caxias em 1875.

A região colonial do Rio Grande do Sul recebeu italianos oriundos de inúmeras cidades do norte situadas, principalmente, nas regiões do Trentino, AltoÁgide, Veneto e Lombardia.

\subsubsection{O Traje Histórico - A Chegada dos Italianos}

As roupas trazidas da Itália, acondicionadas nos navios dentro de caixas e baús, eram poucas e em breve estariam destruídas pelo uso excessivo; e não seria fácil adquirir outras. As lojas logo surgiram nas sedes das colônias, mas o dinheiro era pouco e reservado aos víveres e pagamento das terras. Os alfaiates já haviam se instalado em Porto Alegre ou no interior, mas só os italianos de maiores posses usavam seus serviços. A grande maioria fazia suas roupas em casa. As vestes femininas mais trabalhadas eram feitas por uma das mulheres da família, a mais habilidosa, mas estas vestes muitas vezes, dependendo da família, não existiam, resumindo-se o guarda roupa a peças básicas, com acabamentos bem simples.

Através de relatos de cartas da época, pode-se constatar que em torno de 1884 já existiam lojas de vendas de chapéus, calçados e tecidos na região, mas produtos destinados ao vestuário eram bem mais caros que os adquiridos na Itália.

\subsubsection{Os Trajes Femininos Gaúchos}

Entre 1860 e 1910 a mulher rural gaúcha usava, em dias festivos, a saia lisa com detalhes na barra e o casaquinho. Pequenas modificações ocorreram (a frente 
do casaco, antes de tecido axadrezado ou estampadinho e debruado com tecido liso passa, mais tarde, a receber detalhes verticais no espaço entre o abotoamento ou camadas duplas de debruns. Os casaquinhos, que eram mais curtos no final do século XIX, se tornam mais longos, cerca de um palmo abaixo da cintura). A discrição imperava e a mulher rural sempre optou pelos tons bege e negro.

\subsubsection{O Traje do Colono}

Segundo depoimentos dos italianos e seus descendentes, o traje dominical, depois de um ou dois anos de uso, se tornava a veste diária. Essa troca era feita em ocasiões festivas como natal, páscoa ou casamento, quando se confeccionava um novo traje.

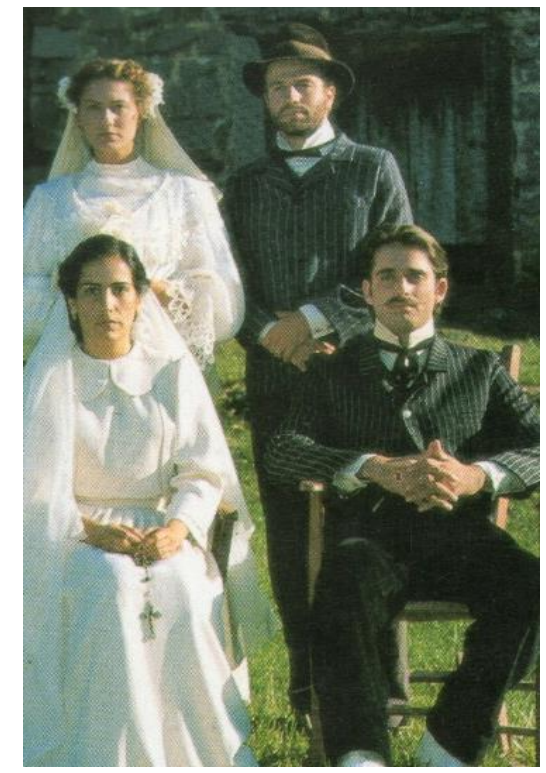

Figura 44 Cena do filme

Quando não era essa a procedência da veste diária, ela era confeccionada em casa, com tecidos fortes como o brim, o fustão ou a lã xadrez. O brim riscado e grosso era o mais comum, usado para forrar colchões, recheados de palha de milho, para os aventais femininos, as calças das crianças e as dos homens para o dia a dia. 


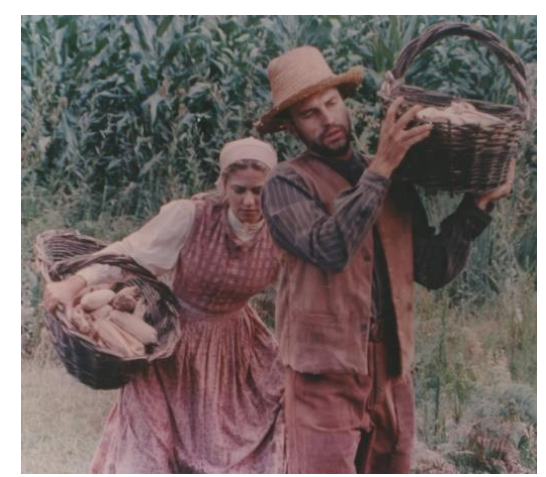

Figura 45 - Cena do filme

A família original italiana de cinco elementos, aqui aumentou de tamanho. Era necessário o máximo possível de mão de obra, sem ônus, trabalhando em sua própria terra. A mãe italiana/gaúcha tinha em média de dez a quinze filhos.

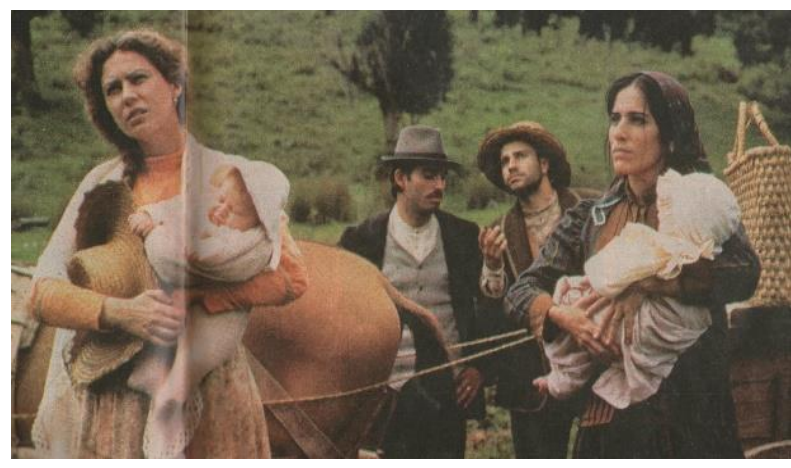

Figura 46 Cena do filme

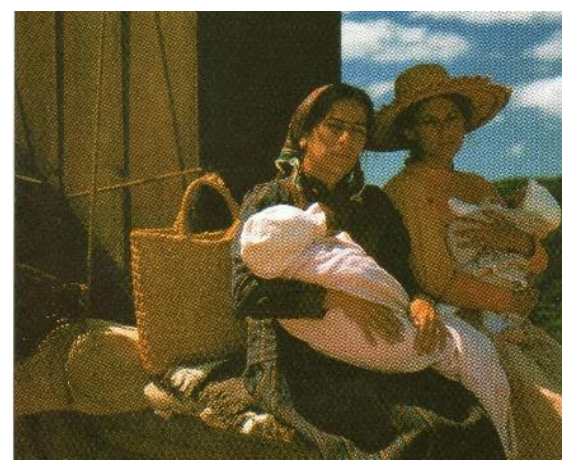

Figura 47 Cena do filme

Todos os colonos eram patrões de si mesmos. Quando não, pretendiam ser donos de suas terras. Consequentemente a mulher imigrante tornou-se uma geradora de filhos, com o corpo sempre em transformação. Daí a origem da "bata" e da saia longa com cadarço na cintura, assim era possível ir alargando a circunferência da saia conforme o tamanho do abdômen. A bata, usada para fora da saia durante a gravidez, era colocada para dentro após o parto e apertada na cintura, se tornando uma nova roupa. 


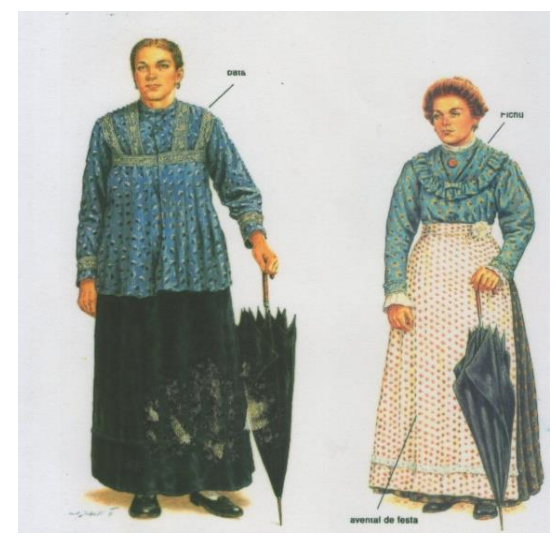

Figura 48 - Bata

Além de gerar filhos as mulheres eram responsáveis pela comida, pela confecção e conservação das roupas da família, pela horta, os animais domésticos e a limpeza da casa; ainda complementando seus dias com seis a oito horas de trabalho na lavoura. O bebe mais novo era levado com ela para o trabalho numa cesta e as crianças de um a cinco anos ficavam com a irmã mais velha em casa.

Era a mulher também que transportava a água da fonte para a casa. A lavagem da roupa e o banho eram feitos num enorme tanque de água corrente colocado ao lado da fonte. O banho completo, em geral, só era tomado aos sábados, dia em que as mulheres também faziam o pão para a semana.

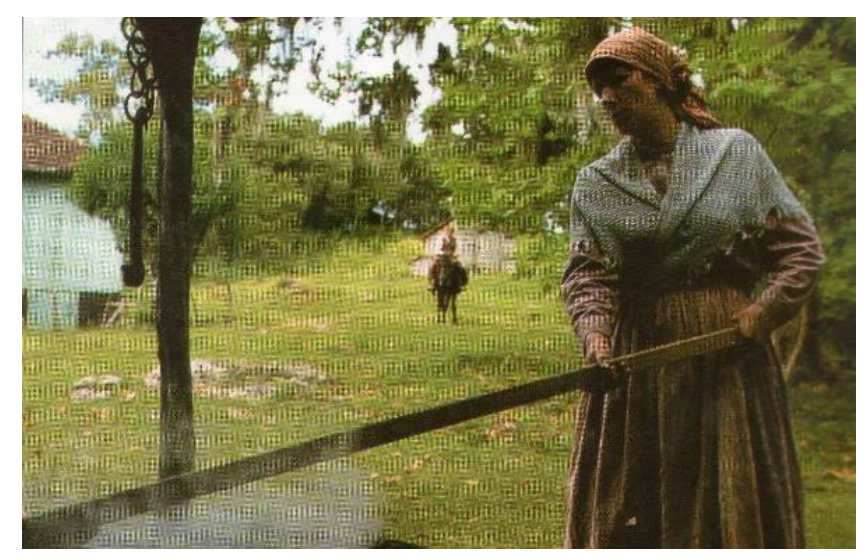

Figura 49 Cena do filme

Quando se plantava o linho ele também era fiado e tecido pelas mulheres, para a confecção de lençóis e peças do vestuário.

Algumas mulheres fumavam cachimbo, mas isso era raro, um hábito das antigas nonnas. 
Os brincos de argola ou com pingentes eram a peça de ouro mais almejada e única joia além da aliança. O broche e a corrente de ouro só eram usados pelas mulheres mais abastadas e apenas em ocasiões festivas.

Não foram encontrados nas pesquisas leques, véus ou livros, a não ser de orações. Há registros de xales, lenços, sombrinhas e travessas de prender cabelo (sempre presos em coques que, ao dormir, elas soltavam, penteavam e trançavam).

Nos ofícios religiosos a tule substituía os lenços e nas mãos levava-se um terço de contas vegetais, no pescoço o escapulário, feito de cordão e pano, era bento pelos padres e carregado pelas mulheres durante toda a vida.

Nas noivas o tule era usado como um tipo de touca que se prolongava nas costas, as vezes até o chão, sendo este o único detalhe além do vestido branco.

A viúva, pelo período de um ano, usava o preto nas vestes; na igreja o tule sempre negro sobre a cabeça. Esse luto seria gradativamente suavizado com tons de cinza ou estampados e pois (bolinhas), em preto e branco. Mas era muito comum as mulheres manterem o luto até sua própria morte. Sendo este um refúgio para afastar a possibilidade de um novo casamento e novos filhos.

Os homens também usavam luto, mas por períodos bem mais curtos. Nas festas, o símbolo do luto masculino era uma faixa de seda preta no braço esquerdo do paletó ou na lapela.

As crianças não vestiam luto, apenas depois dos oito anos era usada a faixa preta no paletó quando da morte de um dos pais. As crianças só usavam paletós aos domingos ou em ocasiões festivas.

A festa de matrimonio era considerada uma das mais importantes, principalmente para os homens. A ocasião em que vestiam o traje mais completo: terno escuro com colete (o terno só seria claro se o poder aquisitivo da família não permitisse adquirir um escuro), sapatos ou botinas sempre novos ou polidos especialmente, lenço no paletó, gravata borboleta (quase sempre) e flor na lapela. Os paletós do século XIX possuíam abotoamento alto, de cinco botões. Já no início do século XX passaram a ter abotoamento simples, com três botões. O cinto era sobreposto às calças sem presilhas. $\mathrm{O}$ bigode era característica muito frequente e motivo de orgulho para os homens.

Para o trabalho os suspensórios eram muito usados, chegando a ser uma marca registrada do colono, assim como o colarinho. As calças, de brim grosso riscado, eram exaustivamente remendadas, se tornando um conjunto de retalhos. 
O chapéu de palha de trigo, também usado em bolsas e outros acessórios e tecido pelas mulheres ao longo do dia, era substituído por um de feltro, no inverno. Meias e sapatos eram usados apenas em dias festivos. Nestes dias, quando se encontravam imigrantes de outras colônias, determinava-se o uso da melhor roupa. Os colonos usavam, então, o guarda-chuva em substituição a bengala, quase sempre inacessível.

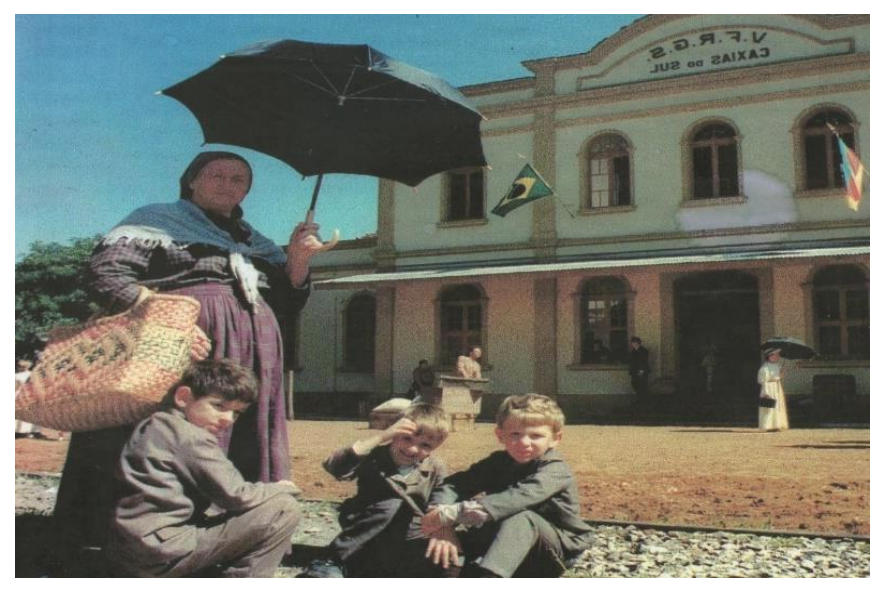

Figura 50 Cena do filme

O convívio com os gaúchos resultou na incorporação de alguns elementos da cultura local por alguns imigrantes, como o lenço no pescoço, as botas e, até, ponchos e bombachas.

No início do século $\mathrm{XX}$ as armas eram muito usadas, a pistola de cano curto, a adaga ou a faca, na cintura, a primeira bem no meio do abdômen e as outras do lado esquerdo, como os gaúchos. As armas de cano longo permaneciam em casa e eram usadas somente para a caça.

O colono em geral não tinha cavalo por falta de recursos, utilizava muares ou carretas puxadas por eles.

Criadas com muito rigor e educadas basicamente pela mãe crianças começavam na lavoura muito cedo, aos cinco ou seis anos, o que as afastava da escolaridade. Elas vestiam trajes de brim, sem roupas íntimas. As calças tinham uma abertura quadrada na traseira do corpo, fechada por botões (para os bens pequenos). As camisas eram feitas com um tecido quadrangular sob os braços para facilitar os movimentos, franzidas nos ombros e sem gola. Isso permitia que as crianças vestissem a mesma roupa por, pelo menos, dois ou três anos. Nos registros fotográficos há crianças com roupas enormes e outras que mal fecham. Calçados raramente eram usados. $\mathrm{O}$ cabelo dos meninos era usado curto e o das 
meninas longo e cacheado. Nos bebês era colocado um cordão ao pescoço com uma noz moscada para atrair felicidade.

\title{
3.2. Carlota Joaquina, a Princesa do Brazil
}

O filme Carlota Joaquina - a princesa do Brazil, símbolo da retomada do cinema brasileiro, conta uma parte da história do Brasil e do mundo, através da controversa personagem de Carlota Teresa Caetana de Bourbon e Bourbon, desde sua infância na Espanha, passando pelo casamento precoce em Portugal, até a fuga e estabelecimento no Brasil da corte portuguesa. Tudo isso narrado na Escócia a uma menina que elabora e constrói as imagens do filme na sua imaginação. São essas imagens que assistimos na tela.

Produção pequena, de baixo orçamento e diretora estreante, o filme caiu como uma luva para o momento histórico em que foi lançado.

\begin{abstract}
É importante repensar o período histórico no qual se deu a produção do filme. Depois de 20 anos de ditadura militar, o primeiro presidente eleito morreu pouco antes da posse e assumiu Fernando Collor de Melo, que com sua política neoliberal deixou a produção de cinema à deriva do mercado e acabou com os órgãos de estímulo à produção cinematográfica (Embrafilme, Concine, Fundação do Cinema Brasileiro). Em um momento de baixa autoestima e com sentimento generalizado de desgosto e desprezo pelo país, o filme Carlota Joaquina marca a retomada do cinema brasileiro, lotando as salas de cinema, mesmo com recursos muito baixos (o dinheiro - R \$ 550 mil - veio de permutas e mais cerca de 100 mil de um Prêmio dado pelo governo). O filme se tornou parte da nova geração da indústria cinematográfica brasileira, com seu roteiro inspirado na narrativa romântica de João Felício dos Santos, chamada Carlota Joaquina, a Rainha Devassa. ${ }^{21}$
\end{abstract}

A ideia aqui é mapear este trabalho, para tentar resgatar cada detalhe da produção do filme. Entrevistas, uma vasta pesquisa literária e iconográfica, auxiliadas pelo fato do filme ter muito material na imprensa virtual, além de artigos e dissertações acadêmicas sobre o mesmo, nos proporcionaram uma base consistente para desenvolver nosso texto.

As referências citadas pelos figurinistas, pictóricas, estilísticas ou cinematográficas foram esmiuçadas a fundo para buscar as origens das pesquisas

\footnotetext{
${ }^{21}$ (www.bocc.ubi.pt/pag/chacon-marques-souza-barcala-cinema-historico.pdf )
} 
dos criadores. As entrevistas abriram um leque de informações que careciam de uma busca mais profunda e detalhada do material de origem. $\mathrm{O}$ recurso da internet, que nenhuma das figurinistas dos três filmes possuía quando desenvolveram seus projetos e suas pesquisas, hoje nos auxilia a resgatar dados, imagens e informações aos quais os criadores não tiveram acesso na época.

Nosso olhar, que chamamos de "quarto corpo histórico", é o que deve ficar como registro dessa experiência.

A direção de arte, o cenário e o figurino do filme são assinados por Tadeu Burgos ((Rodolfo Tadeu Baumann Burgos (1961-1994)), de origem teatral e Emilia Duncan, Marcelo Pies entrou depois para encorpar a equipe de figurino, que ainda contou com as participações (fundamentais, nas palavras dos criadores) de D. Antonia, D. Helena, Sr. Levy e Divina, todos da equipe do Teatro Municipal do Rio de Janeiro na época. A arte e o figurino, assinados pelo trio, harmonizam com a fotografia, a direção e a dramaturgia de uma forma que denuncia o perfil "artesanal" do filme.

$\mathrm{Na}$ entrevista concedida a nós, Emilia Duncan se define como uma pessoa de pesquisa e concepção que, diante da necessidade de realizar figurinos, decidiu estudar moda na FIT (Fashion Institute of Thecnology da State University of New York), onde aprendeu a desenhar e a construir tecnicamente uma roupa.

Segundo ela, sua participação e o resultado final do filme se devem a genialidade de Tadeu Burgos. "O Tadeu me deu todo o embasamento no teatro. Nós tivemos uma parceria na moda dos anos oitenta (a chamada "geração 80" surgiu nesse contexto) quando houve vários eventos de vanguarda no Parque Lage, Rio de Janeiro. Eu comecei minha experiência profissional em publicidade e cinema, me faltava a questão cênica, a vivência do teatro. A ausência da câmera, a presença do público, a caixa cênica, a luz, o tamanho real, a distância, eram estranhos para mim. “

Através da proximidade com Tadeu, Emilia passou a fazer mais teatro e foram eles que apresentaram a produtora Bianca de Filipes (que tinha um trabalho muito eficiente com teatro de pouco recurso) a Carla Camurati (diretora do filme), já que esse era o caso do filme Carlota. Essa parceria viria a durar longos anos.

Segundo Emilia, a grande pesquisa de conteúdo foi feita pela diretora (Carla), ajudada pelo escocês Angus Mitchell, roteirista do filme, que trouxe para ela toda a questão do reinado (dois livros cujos títulos a entrevistada não 
recordava). “Um deles, escrito logo no começo da república e que tinha toda uma propaganda antimonarquista, um olhar de deboche para a monarquia. ” [...] "Num primeiro momento eu cheguei a questionar esse viés do ridículo. Eu sou historiadora, formada em história, tive uma primeira reação de antipatia com o tom jocoso".

Lara Leal fez a pesquisa visual. Na época, havia uma grande dificuldade para pesquisa e, enquanto Lara pesquisava a parte das "brasilianas" (Debret, Regendas etc.) Tadeu e Emilia trabalhavam com a pesquisa internacional nos livros (a figurinista havia trazido muito material na volta dos estudos nos Estados Unidos que, na época, não estava disponível no Brasil). Todas as referências a moda da corte europeia (começo do século XIX) antigo regime e virada do antigo regime. É uma época em que há uma virada dos hábitos e costumes, uma grande ruptura visual, uma mudança comportamental. Isso ajuda na elaboração de um conceito por parte da equipe de criação.

"Este é um filme totalmente atípico. Nós nos dispusemos a trabalhar sem ganhar, mas tínhamos todo o tempo do mundo. Houve tempo de sobra para pesquisa, elaboração de conceitos, opções estéticas”.

No começo a diretora queria filmar em Queluz (usar locações portuguesas (mesmo que o viés já fosse não realista na dramaturgia), um ambiente naturalista nas locações. Com a entrada da produtora Bianca e o olhar da dupla de criadores, começou-se a conduzir uma produção mais teatral, que era a única maneira de viabilizar o projeto sem recursos que tinham em mãos. "Fomos nós que colocamos para a diretora que, além da falta de dinheiro, não seria possível juntar uma peruca de nylon com uma parede do Palácio de Queluz. Se a opção estética era por uma transgressão, ela teria que ser generalizada. E a falta de verba corroborava com isso. São duas linguagens que podem dialogar, desde que haja estrutura".

Se observarmos produções de época realizadas desde então, veremos que esta declaração da figurinista não exatamente se justifica; filmes, peças de teatro e, principalmente séries de televisão (a série Reign, atualmente em exibição no Netflix, é um exemplo) produzidos ao redor do mundo, misturando épocas e estilos e muitas vezes figurinos atemporais, anacrônicos ou simplesmente inventados em cenários reais (como vários castelos europeus), contrariam esta declaração. 


\subsubsection{Referências}

A figurinista cita como referências os cineastas Peter Greenaway e Derek Jarman, os dois têm uma abordagem para a história e para o filme histórico muito particular. Greeenaway era pintor e foi para o cinema para ser diretor de arte. "Ele tinha o desejo de exprimir aquela estética dele, uma estética alucinada e que me alucina. O Jarman me intrigava porque ele misturava linguagens e tinha menos verba" (CARAVAGGIO, 1986).

Esse foi o arcabouço estético que Duncan e Burgos apresentaram à diretora: A liberdade com a época. "O fato de eu ter estudado história me deu uma liberdade em relação a ela que as pessoas em geral não têm. As pessoas têm um respeito cego pela história e os livros de história. O professor Francisco Calazans dizia que história não é ciência, história é interpretação. O documento fala, mas a pergunta quem faz é você. Não importa quantas pessoas tenham acesso à fonte, ela será sempre subjetivada. Tudo é subjetivado!"

Voltamos aqui a questão do corpo histórico. Parece-nos uma maneira simplista de observação o que Duncan chama de "subjetivado", como se as "fontes" ou "objetos" fossem estanques e só o olhar dos sujeitos sobre eles variasse. Com a frase "o objeto fala, a pergunta quem faz é você”, a figurinista congela um elemento ou fato histórico ao invés de flexibilizá-lo e dar-lhe vida própria. Os corpos históricos não são estanques, são mutantes através da história e sempre o serão enquanto exista história. Por isso é impossível defini-los; podemos supô-los, imaginá-los e reconstruí-los, mas serão novos corpos. Mesmo um objeto histórico palpável, como um filme, um livro ou uma escultura, apesar de rijo em sua forma física irá inevitavelmente mudar no decorrer de sua trajetória histórica. "Eu estudei moda sob um viés profundo. Me interessava a palavra contemporaneidade. O que a moda representou nos anos 80 no Brasil tem muito a ver com a individuação da pessoa. $\mathrm{O}$ meu interesse pela moda e o vestuário foi minha maneira de abordar e atravessar a imagem ligada a questão histórica. " Aqui, de maneira tangencial e poética nos vêm as palavras de Agamben.

A contemporaneidade, portanto, é uma singular relação com o próprio tempo, que adere a este e, ao mesmo tempo, dele toma distâncias; mais precisamente, essa é a relação com o tempo que a este adere através de uma dissociação e um anacronismo. Aqueles que coincidem muito plenamente com a época, que em 
todos os aspectos a esta aderem perfeitamente, não são contemporâneos porque, exatamente por isso, não conseguem vê-la, não podem manter fixo o olhar sobre ela (AGAMBEN, GIORGIO, 2006, p. 59).

Emilia diz que a dupla tinha um patamar filosófico e, ao mesmo tempo, um patamar concreto. Qual era o patamar concreto? O Tadeu era um homem de teatro, ele tinha sido aluno e assistente do Luis Carlos Ripper (1943 - 1996, cenógrafo, figurinista, diretor e iluminador) e trouxe com ele essa bagagem. “Antes do Tadeu eu tinha medo da matéria, tinha medo de cortar pano, dos detalhes perfeitos que a moda exige. Quando encontrei o teatro do Tadeu fui jogada na vertigem, no dionisíaco, na loucura, na reapropriação da matéria, na destruição da matéria, no envelhecimento sem dó nem piedade, na repintura..."

Ana Maria de Moraes, artista plástica que trabalhou com Celeida Tostes era a responsável pelos tratamentos, envelhecimentos e tingimentos. "Isso foi muito importante porque nós trabalhávamos com o que tínhamos, não compramos quase nada. Só me lembro de ter comprado tecidos para alguns figurinos dos personagens principais, o resto era doado e tinha que ser transformado."

O critério para essa transformação foi o conceito. Pode se dizer que esse filme foi construído sobre um conceito, que gerou uma paleta de cores, que estabeleceu grupos estéticos e, consequentemente, cromáticos (Espanha, Portugal, Brasil) e só após isso foi criado o figurino. Ou seja, a direção de arte e o figurino estavam solidamente estruturados sobre uma concepção conceitual prévia, o que dava uma margem de manobra muito grande e muito segura. "Como podíamos lidar com todo esse material diverso, das doações, que não tinha nenhuma identidade e não havia sido escolhido por nós? Para isso foi fundamental termos conceitos muito amarrados, porque em cima dos conceitos podíamos olhar para o material de outra forma."

A narrativa da cor e da forma pré existia. Foi conceituada toda a narrativa estética em função da narrativa dramática e emocional, onde nada era à toa.

Tudo o que Emilia diz nesta entrevista, somado à entrevista com Marcelo Pies, o outro figurinista, nos dão uma noção fundamentada e esclarecedora do que assistimos na tela. 
O filme Carlota Joaquina, a princesa do Brazil possui uma estrutura e uma produção originalmente teatrais, sem deixar de ser cinema. Fica claro aqui que essa prática e essa estética oriundas da experiência com o teatro permitiram, não só a viabilidade do filme, como seu sucesso. Provavelmente isso se dá devido às outras cabeças de área envolvidas no projeto: roteiro, fotografia, montagem, terem vindo do cinema. O filme não possui uma estética teatral, a forma e a linguagem vistas na tela são cinematográficas (é importante lembrar que o cenário e o figurino de cinema no Brasil têm suas raízes em nomes como Aniso Medeiros, Luis Carlos Ripper e Kalma Murtinho, dentre muitos outros de formação teatral).

Porém, o que nos interessa aqui é o processo, o projeto de produção do figurino e a construção do corpo histórico do filme. Estes têm, sem dúvida, um perfil teatral, diferentemente dos outros dois filmes que analisamos nesse trabalho.

O tempo de criação (quase um ano), somado à precariedade de recursos, erigiram um formato característico de produção e, consequentemente, de estética e plástica cinematográficas. Este é o diferencial do filme.

Um fotografo brasileiro, Flavio Ferreira, costuma dizer que para se fazer cinema é necessário tempo ou dinheiro. Com tempo e sem dinheiro é possível produzir, com dinheiro e sem tempo também. Sem tempo nem dinheiro estarás produzindo no inferno e, com tempo e dinheiro no paraíso.

Carlota Joaquina, dos filmes que analisamos aqui é o de menor orçamento de produção, e também, a maior bilheteria.

Carlota se tornou o marco inicial da chamada retomada porque, pela primeira vez em muitos anos, o público quis ver um filme brasileiro. "Quando ele fez aquele sucesso, foi como um banho de esperança de algum dia eu poder vir a fazer um longa", confessa Fernando Meirelles (renomado diretor brasileiro), que havia abandonado o sonho do cinema pela TV na época.

Chama-nos particularmente a atenção o processo artesanal, quase mambembe, dos figurinos e a qualidade do seu produto final na tela. Toda essa "elaboração de conceito" mencionada pelos figurinistas se mostra como um esteio, uma âncora, para o filme. Os depoimentos nos dão a entender que o filme só teve o resultado positivo que vemos nas telas e na mídia devido a essa elaborada construção de um conceito extremamente fundamentado; isso foi possível graças ao elemento tempo. 
Outra questão, além do processo de produção, que nos interessa particularmente neste trabalho, é o processo de pesquisa. A pesquisa, em geral, é o primeiro passo (após, ou paralelamente, a leitura do roteiro) para o figurinista e o diretor de arte. Não existe filme de época sem pesquisa. Na verdade, considero a pesquisa como cerne de qualquer produção cinematográfica, seja ela de época ou não. O que orienta nosso trabalho aqui são as diversas formas e interpretações do trabalho de pesquisa e como isso imprime no produto final. É importante lembrar que as duas figurinistas entrevistadas têm formação em história, o que ajuda quando se trata de filme de época.

Sobre as referências, de bagagem ou de pesquisa específica para o projeto, Emilia menciona sempre o lado semiológico da história. Sua metodologia começa com o emocional, o sentimental, que podemos traduzir como dramaturgia. Depois entra a pesquisa iconográfica, Goya e Rembrandt são mencionados como pintores que estão presentes em suas referências, além dos cineastas Peter Greenaway e Derek Jarman. Ambos fizeram versões da peça A Tempestade, de Shakespeare

Greenaway não só reverencia a pintura em seus filmes como fez uma obra, A ronda da noite (Nightwatching, 2007) totalmente baseada no quadro homônimo de Rembrandt.

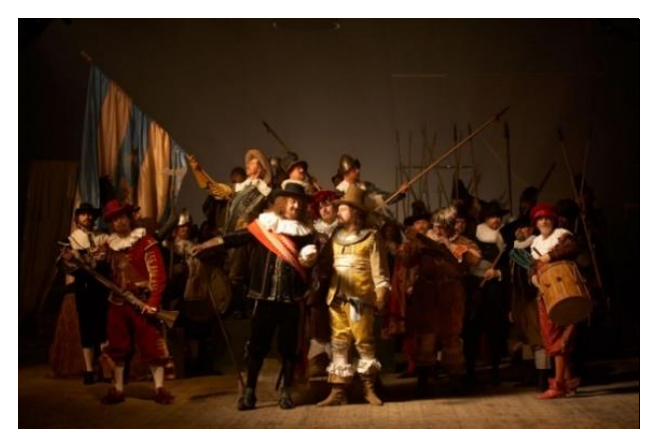

Figura 51 - Cena do filme A Ronda da Noite

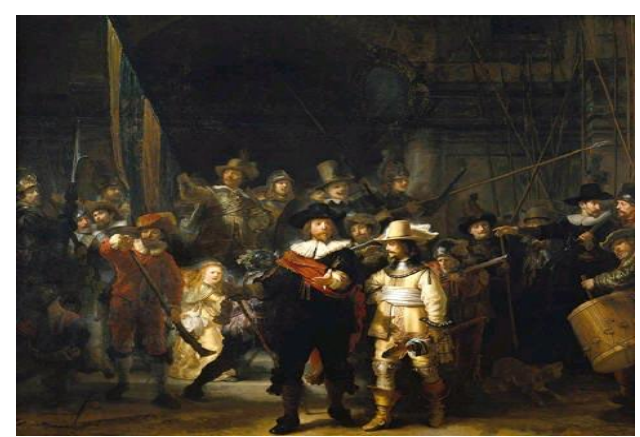

Figura 52 Quadro de Rembrandt 
Seu filme $O$ cozinheiro, o ladrão a mulher $e$ o amante, tem várias referências pictóricas, inclusive reproduções cênicas de quadros holandeses.

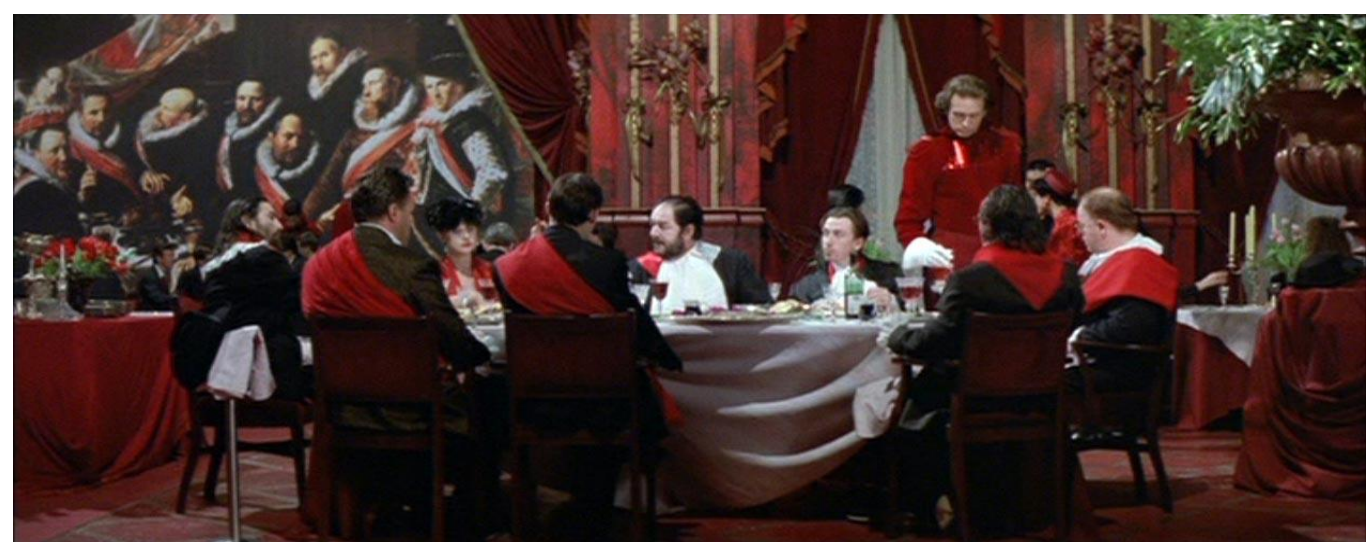

Figura 53 Cena do filme $O$ cozinheiro, o ladrão a mulher e o amante

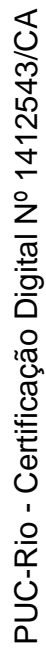

O figurino de Jean Paul Gaultier e a alegoria que faz com que eles mudem de cor a cada cenário.

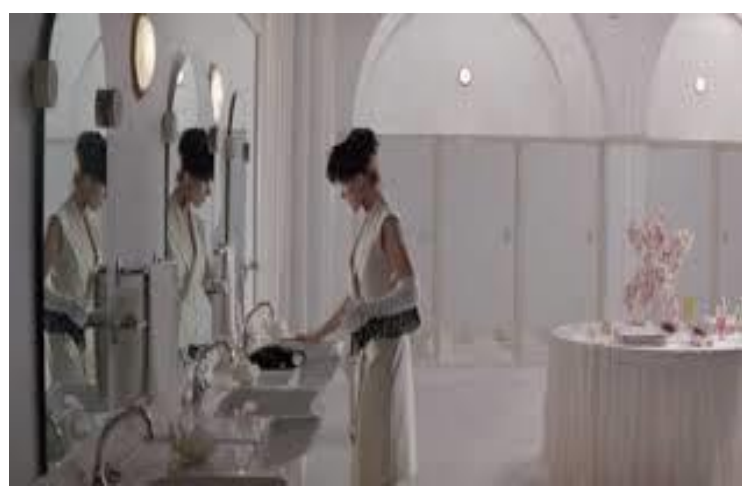

Figura 54 Cena do filme $O$ cozinheiro, o ladrão a mulher e o amante

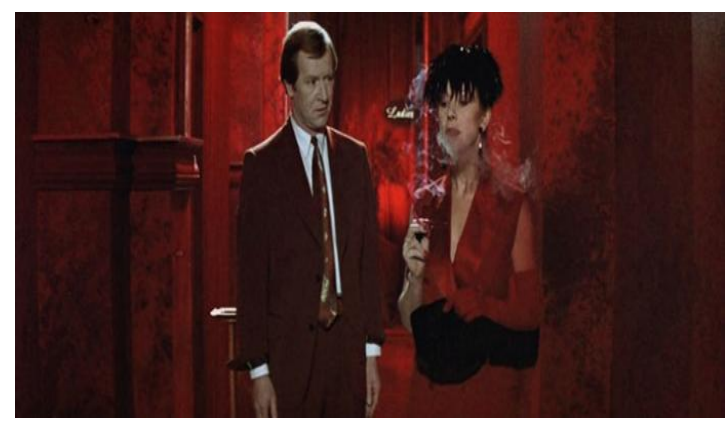

Figura 55 Cena do filme $O$ cozinheiro, o ladrão a mulher e o amante 
Duncan afirma ter usado o filme como inspiração para a cena em que o casamento no leito, todo branco, se transforma em velório, no mesmo leito, com o recurso de jogar tinta preta sobre os figurinos feitos de entretela de papel.

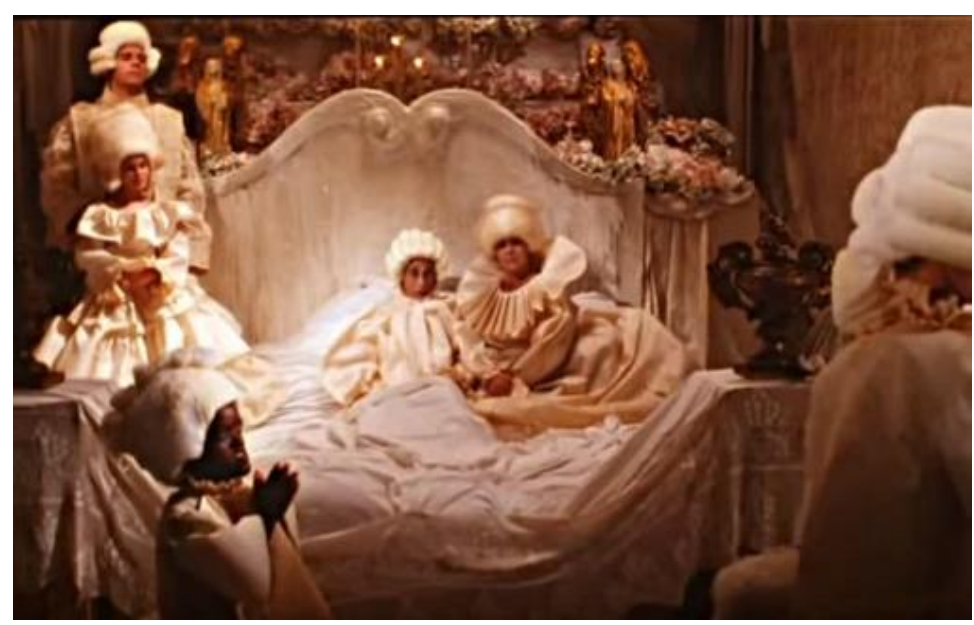

Figura 56 Cena do filme Carlota Joaquina

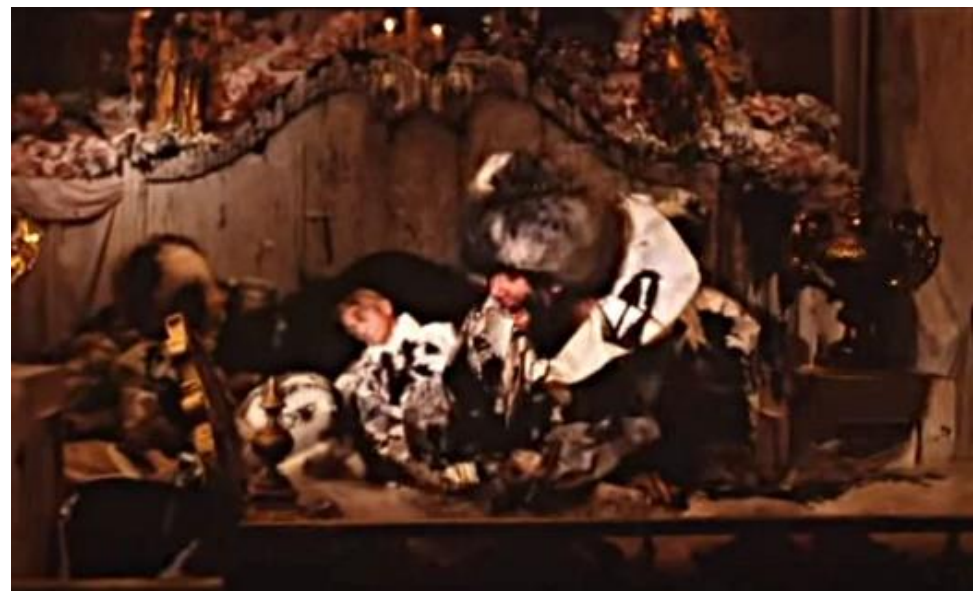

Figura 57 Cena do filme Carlota Joaquina

Jarman, em sua Tempestade (The Tempest, 1980) trabalha muito com a essência e usou a alta costura, nas palavras da figurinista: "A rainha era a quintessência de uma rainha, independentemente da época”. 


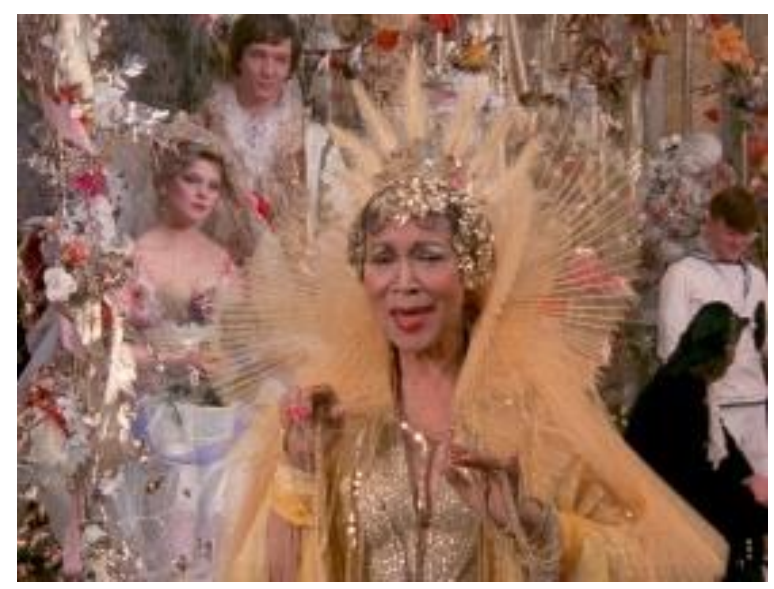

Figura 58 Cena do filme Tempestade de Jarman

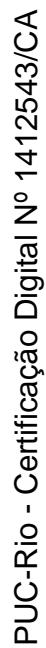

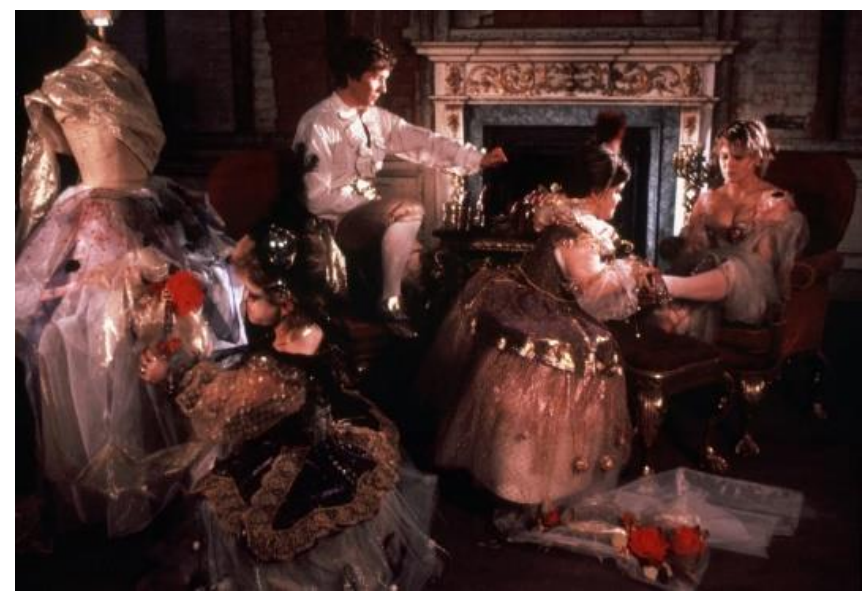

Figura 59 Cena do filme Tempestade de Jarman 


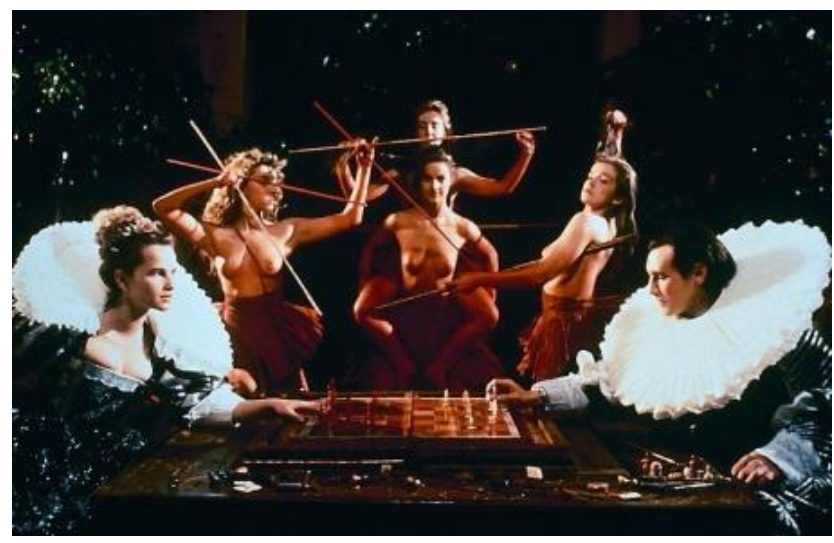

Figura 60 Cena do filme Tempestade de Peter Greenaway

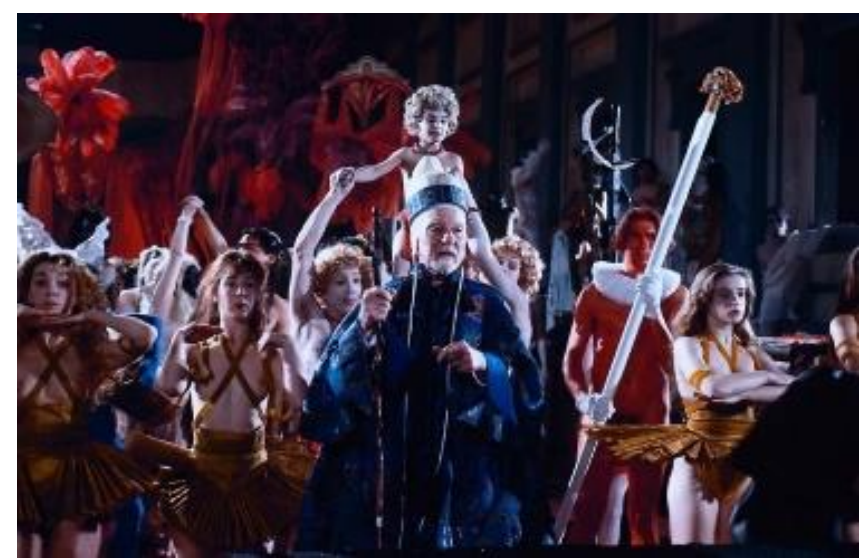

Figura 61 Cena do filme Tempestade de Peter Greenaway

\subsubsection{Cores}

O filme trabalha com uma paleta de cores psicológica e geográfica bastante clara, que prescinde da argumentação dos figurinistas. A estratificação das cores por países é óbvia para os sentidos, mesmo que o espectador desconheça qualquer questão histórica. Somar o elemento histórico ao fator psicológico é uma maestria para poucos. Aqui, a obviedade das diferentes paletas por países se sustenta no conceito e na exacerbação permitida pela comédia.

A Escócia, onde em um rochedo a beira do mar a história é contada pelo tio à menina Yolanda no tempo presente da narrativa, é azul e realista (mantendo, dentro do conceito, uma certa atemporalidade, quando seria esse tempo presente?). 


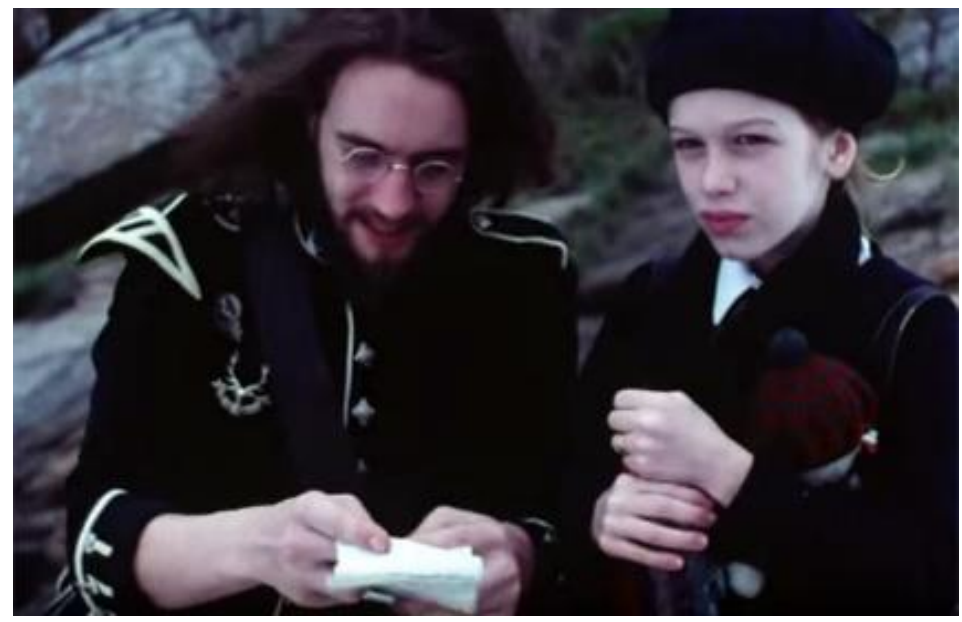

Figura 62 Cena do filme Carlota

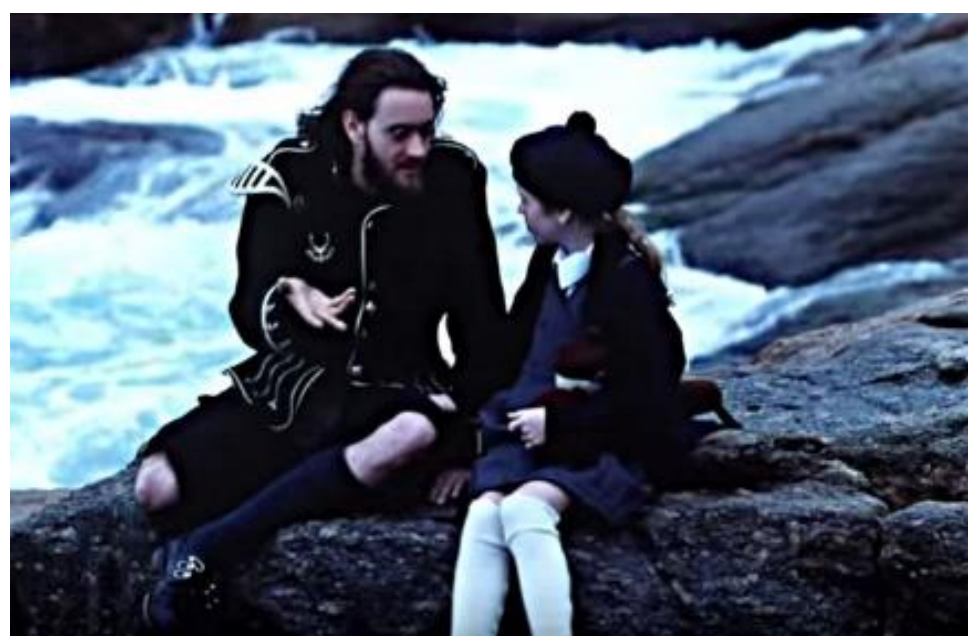

Figura 63 Cena do filme Carlota

A Espanha é quente, dionisíaca, basicamente vermelha, com nuances de roxo, negro e dourado.

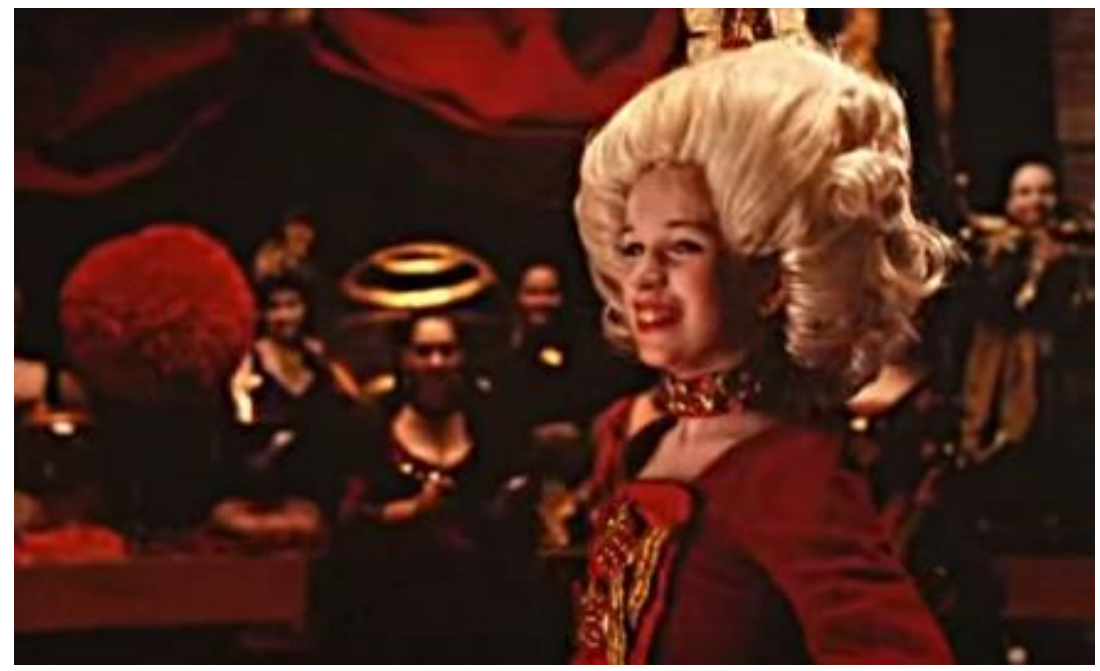

Figura 64 Cena do filme Carlota 
O figurino roxo, a peruca monumental e ruiva e as pérolas negras da mãe de Carlota (Vera Holtz no papel de Luisa de Parma), as roupas vermelhas da infanta e a iluminação com fogo, somadas a quase nauseante câmera e a fotografia de Breno Silveira nos colocam em um universo de calor e festividade eternos, quase onírico.

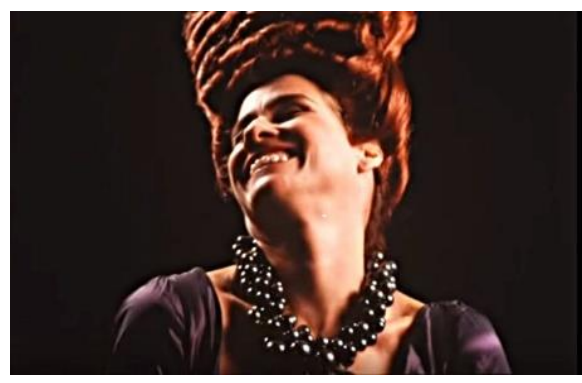

Figura 65 Cena do filme Carlota

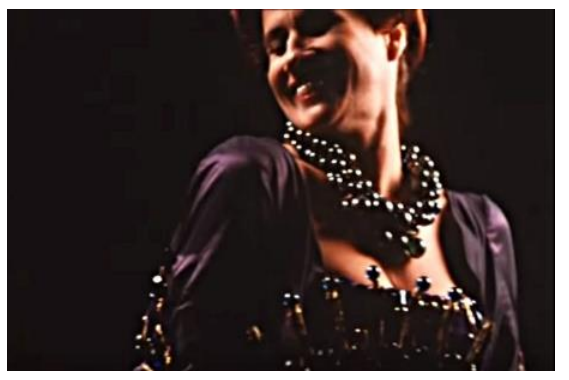

Figura 66 Cena do filme Carlota

Portugal aparece com os brancos, não vistos até então, e os negros. Símbolos religiosos e o contraponto branco e negro estarão presentes nesse território onde uma menina perdida em um lugar velho, morto, doente, excessivamente católico e saído de uma recente tragédia (o terremoto de Lisboa em 1755 que, durante a pesquisa, descobriu-se ter sido muito mais do que um simples terremoto, houve um tsunami, grandes incêndios, uma catástrofe que destruiu uma das capitais mais pujantes da Europa, só reconstruída pelo Marques de Pombal [baixa pombalina]). A luz de velas, aqui diferentemente da estética espanhola, ilumina os brancos e esfria o contexto, enfatizando a religiosidade e o pudor, tudo é mais frio e contido.

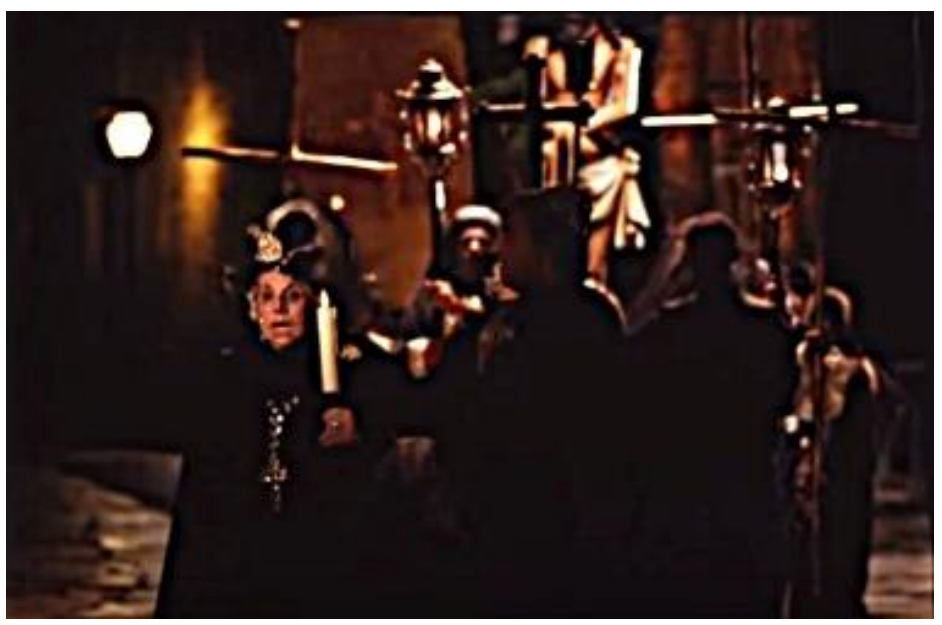

Figura 67 Cena do filme Carlota 


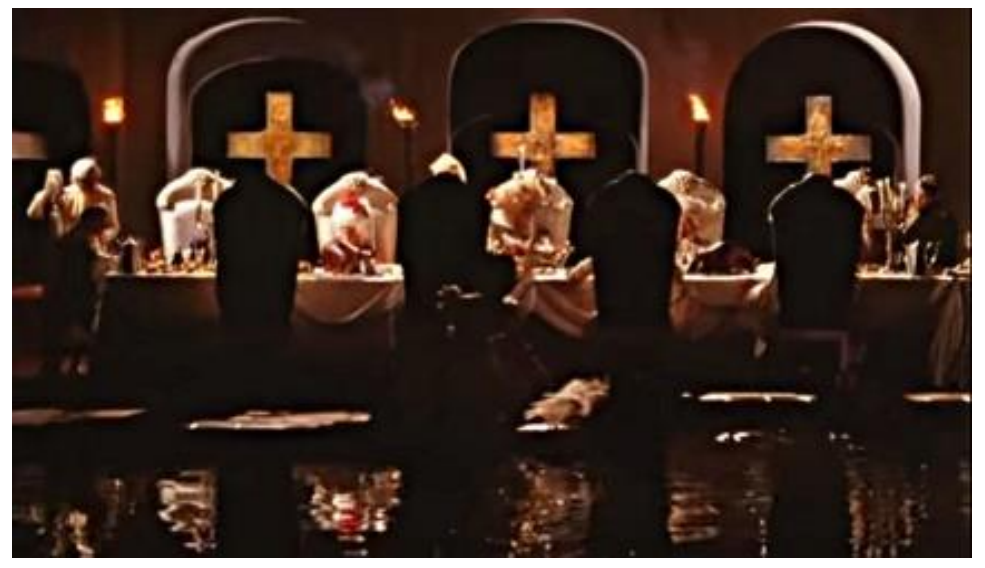

Figura 68 Cena do filme Carlota

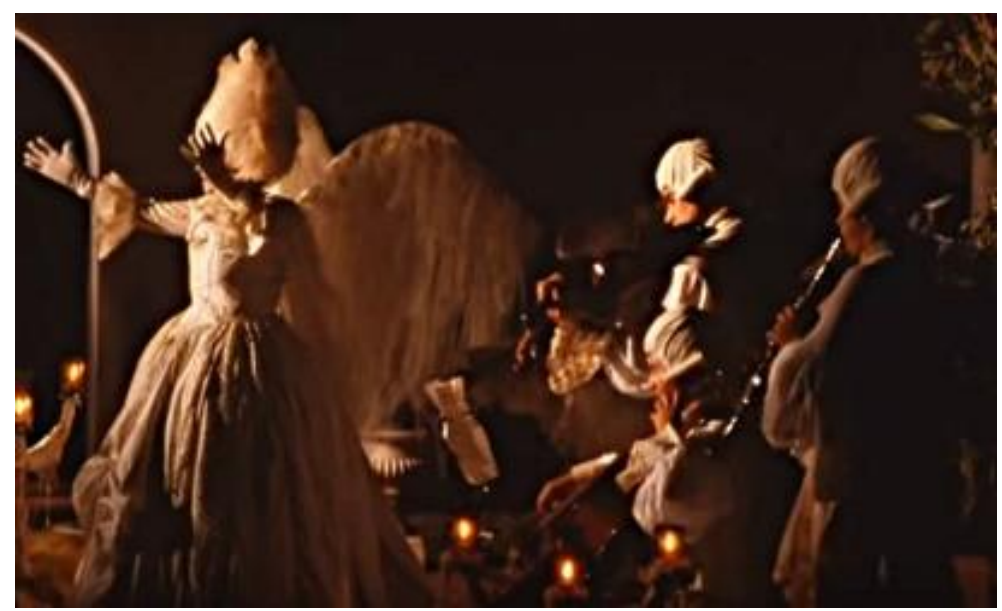

Figura 69 Cena do filme Carlota

O Brasil é uma grande feira colorida, caótica e alegórica, com muitas misturas, estampados e chita.

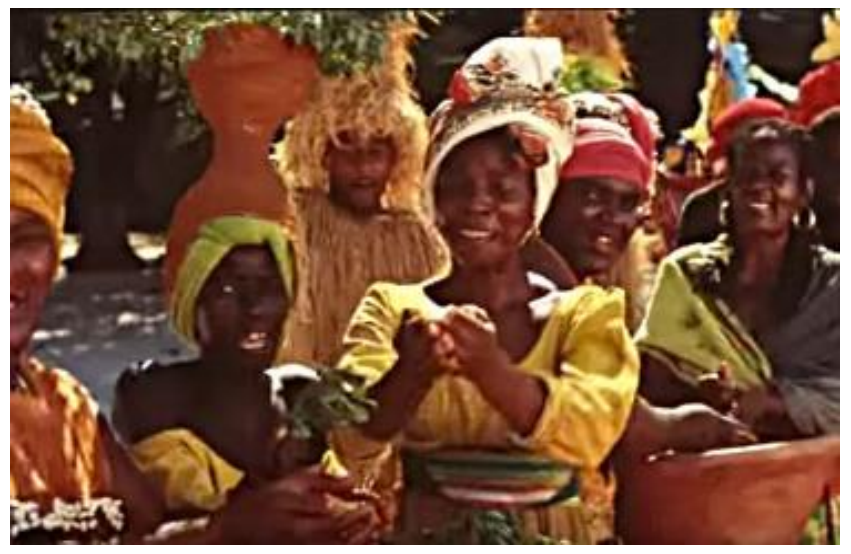

Figura 70 Cena do filme Carlota 


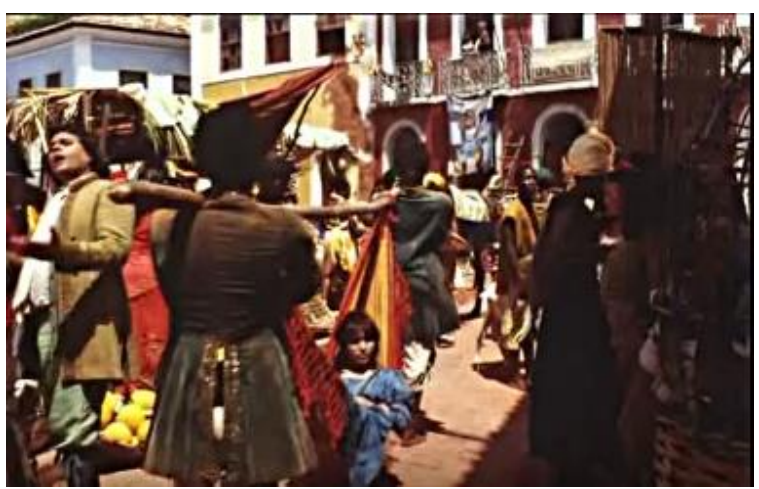

Figura 71 Cena do filme Carlota

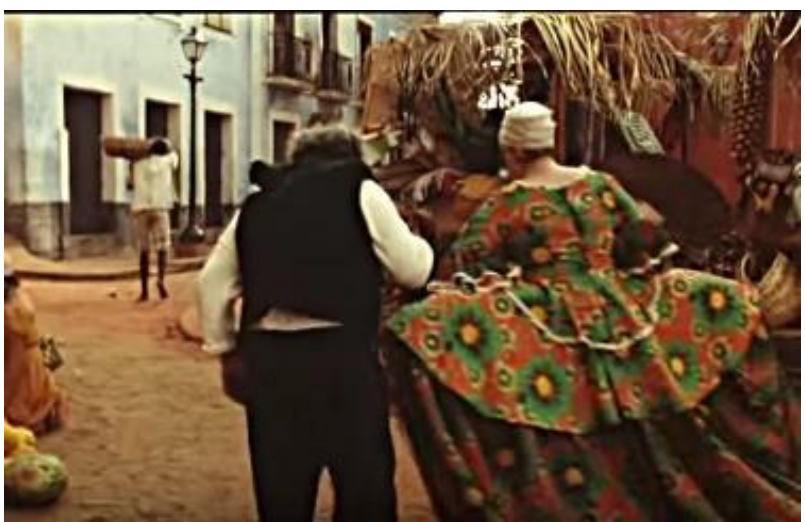

Figura 72 Cena do filme Carlota

$\mathrm{Na}$ chegada a Bahia a corte é recebida por nativos com pinturas corporais inspiradas na Timbalada (foto), os negros usam acessórios de palha e perucas de sisal (como o criado pessoal de Carlota, inspirado no Curupira).

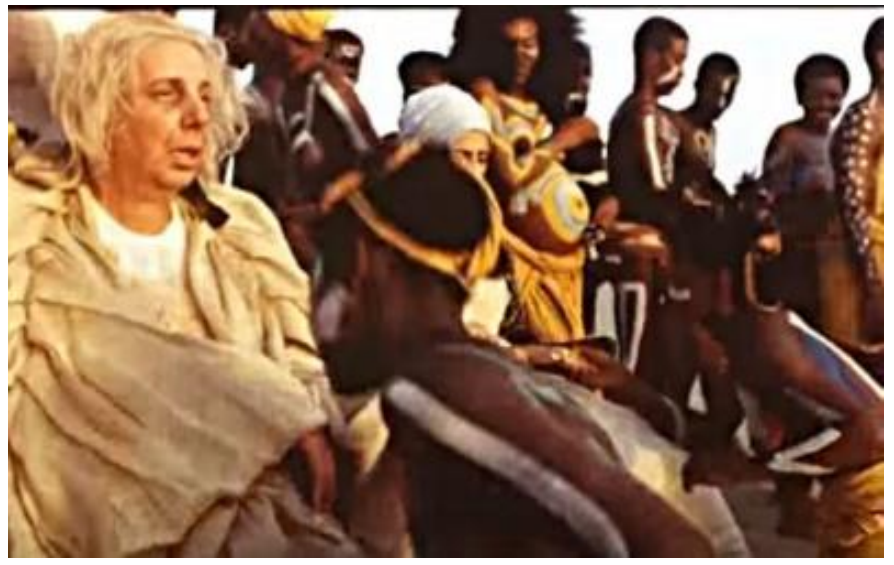

Figura 73 Cena do filme Carlota 


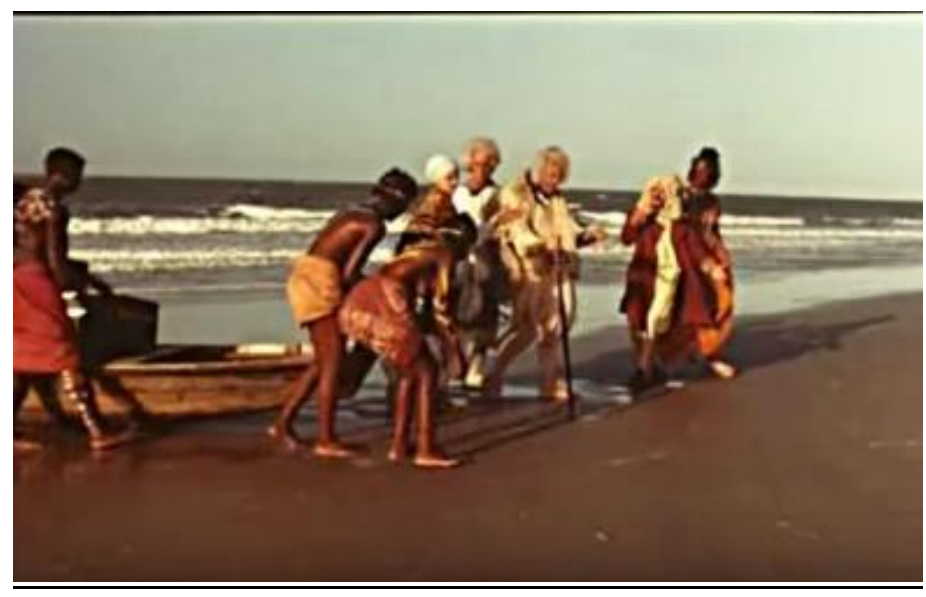

Figura 74 Cena do filme Carlota

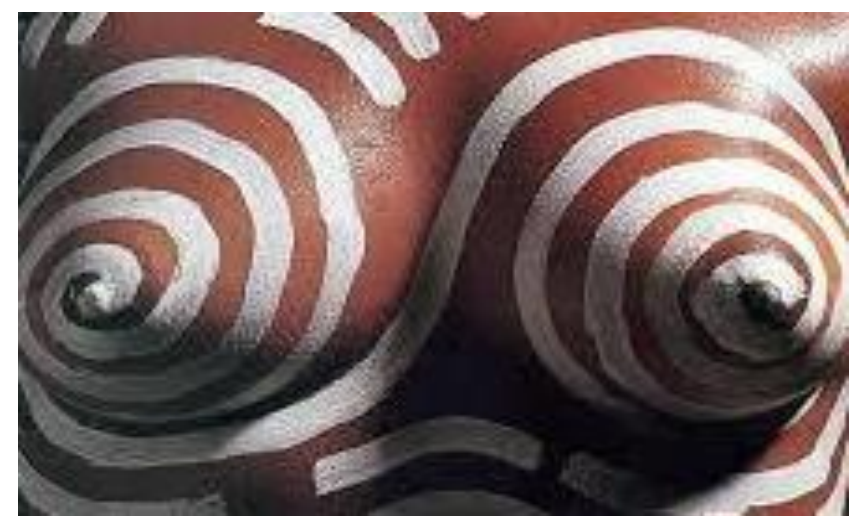

Figura 75 pintura Timbalada

Tadeu e Emilia fazem isso de uma forma controversa para muitos, porém conscientemente escolhida. O visual é muito mais barroco do que rococó, segundo a figurinista, eles queriam falar sobre a potência de Espanha e Portugal no auge do barroco. Ali os detalhes e a fidelidade à época são menos relevantes do que o impacto do todo. Fica claro que essa é a proposta, a busca da essência e da significação. Nesse sentido, não há erro histórico. O conceito está acima da reconstituição. Soma-se a isso o fato da narrativa do filme estar sendo ouvida por uma menina escocesa e desenhado na sua imaginação, o que permite a fantasia, a alegoria. É como se as imagens surgissem da cabeça e dos olhos dessa menina. 


\subsubsection{Personagens}

Carlota, como a Espanha, é vermelha, sanguínea e passional. Sua personalidade temperamental e esfogueada faz seu figurino com cores quentes. Desde criança já é sua marca, sempre com uma pitada de ironia (como o vestido com peixinhos e peruca com adereço de caravela). Os figurinistas usaram a essência, o perfil da personagem, mas também pesquisaram as infantas de Velásquez, apesar de Carlota ser posterior (no filme a personagem de Carlota jovem tem obsessão pelo retrato da infanta Margarida).

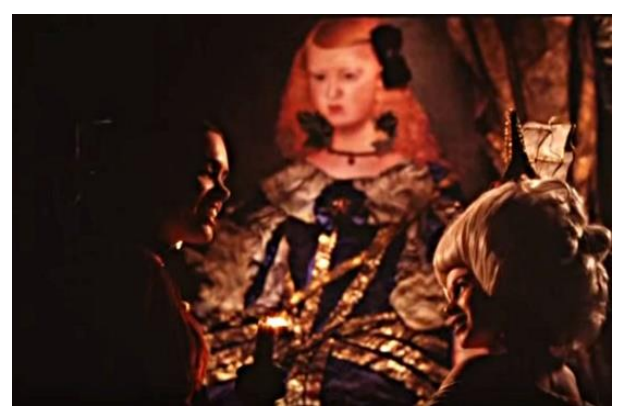

Figura 76 Cena do filme Carlota

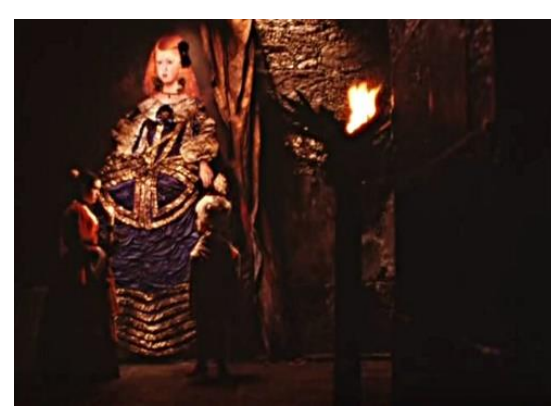

Figura 77 Cena do filme Carlota

O fato da mesma atriz interpretar a menina escocesa e a infanta, fortalece a argumentação de um mundo imaginário e onírico, permitindo aos criadores uma liberdade com a história e a época que seria muito recriminada por alguns, mas que, indubitavelmente, está escorada na construção do roteiro.

As citações sobre referências e pesquisas demonstram que não havia irresponsabilidade ou falsas intenções por parte dos criadores. O que está na tela é intencional, pensado e argumentado devidamente.

Isto cria uma estética particular que é a assinatura do filme, independente dos critérios de gosto ou valor, justificada em suas imagens projetadas na tela.

Os vestidos da infanta Carlota eram feitos pela modista de Maria Antonieta, Rose Bertin, mas o filme não é fiel a isso, fazendo seu figurino mais barroco do que rococó. 

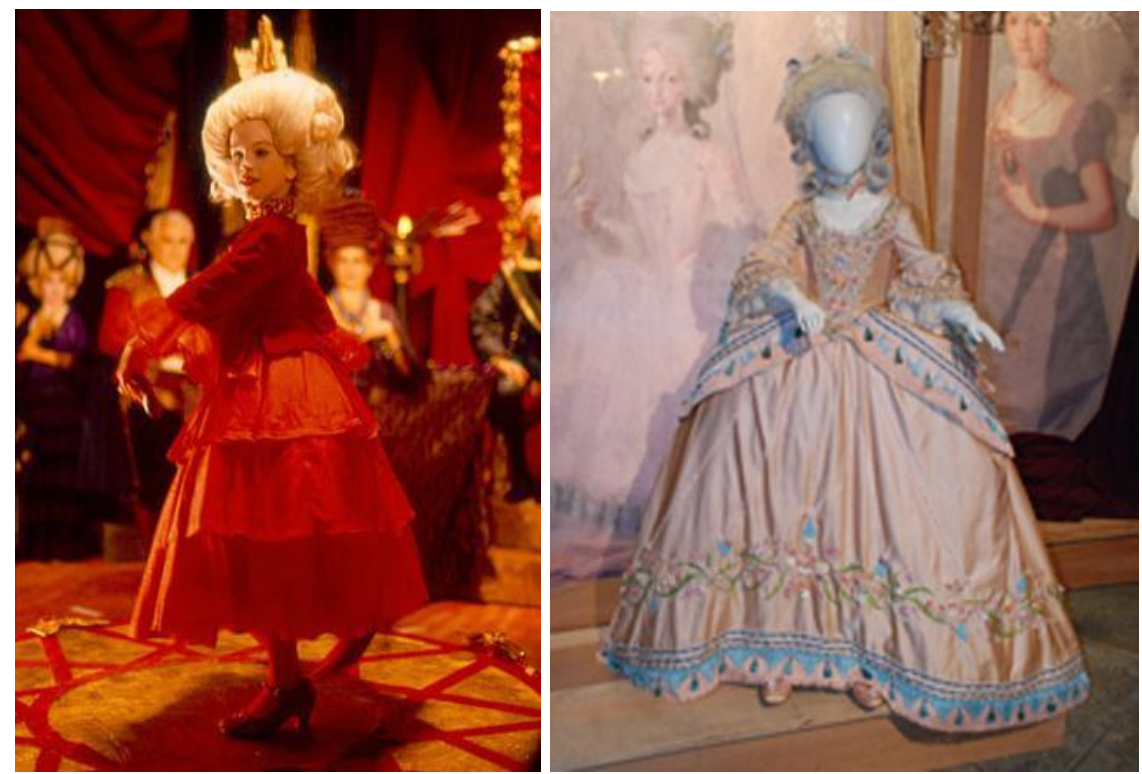

Figuras 78 e 79: À esquerda cena do filme com a infanta Carlota e seus vermelhos. Na imagem à direita, um vestido copiado do original apresentado em uma exposição no Rio de janeiro* com curadoria da mesma Emilia Duncan

Na Carlota adulta (Marieta Severo), o material usado, em geral é seda.

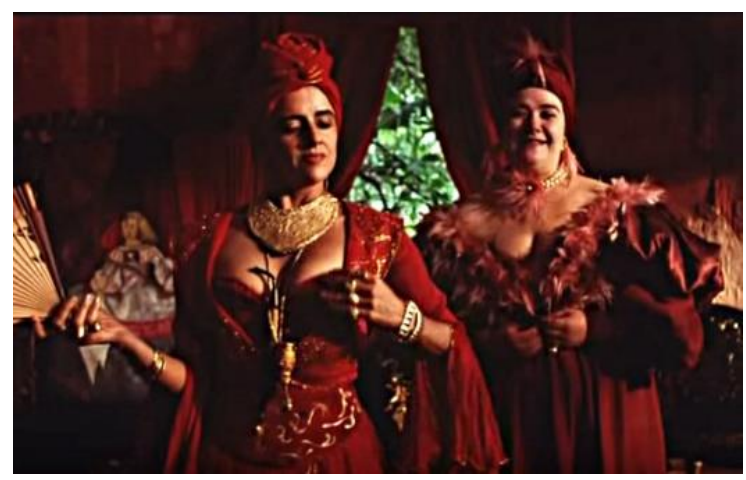

Figura 80 Cena do filme Carlota

O corte não foge completamente ao estilo Império, em voga na época pós revolução francesa, mas possui particularidades e extravagâncias acrescentadas pelos autores, como o espartilho cortado para valorizar o seio, inspirado no trabalho da Viviane Westwood dos anos 1970. 


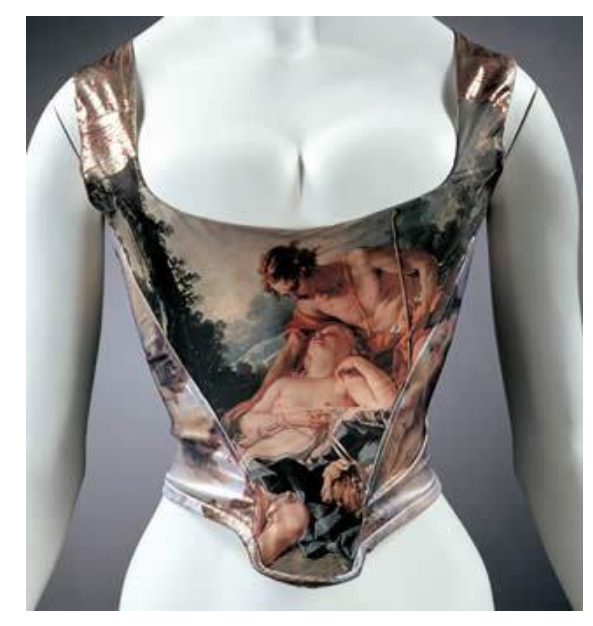

Figura 81 Corpete Westwood

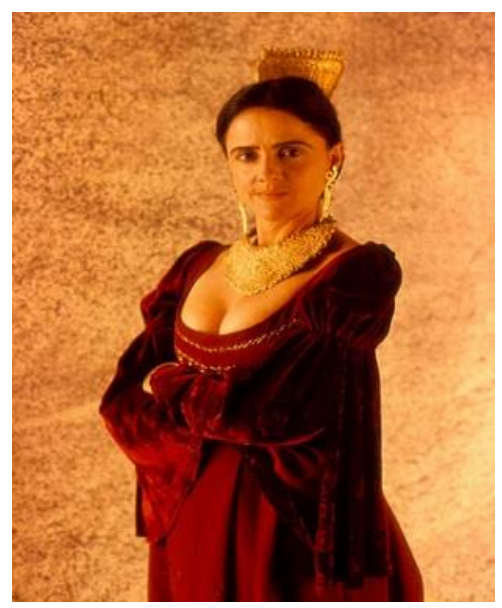

Figura 82 Cena do filme Carlota

Carlota é uma mulher que vive entre dois mundos e, consequentemente, sua indumentária acompanha esse movimento. A infanta viveu na Espanha antes da revolução, com todas as ostentações da nobreza. A mulher adulta, pós revolução, foge de Napoleão mas carrega consigo traços da modernidade, ela usa trajes masculinos de montaria, calça com culotes e algibeira, ela inova na sua maneira de vestir. Pode-se dizer que Carlota possui os maneirismos dos tempos de transição e não deixa de ser "moderna" em suas contradições. 


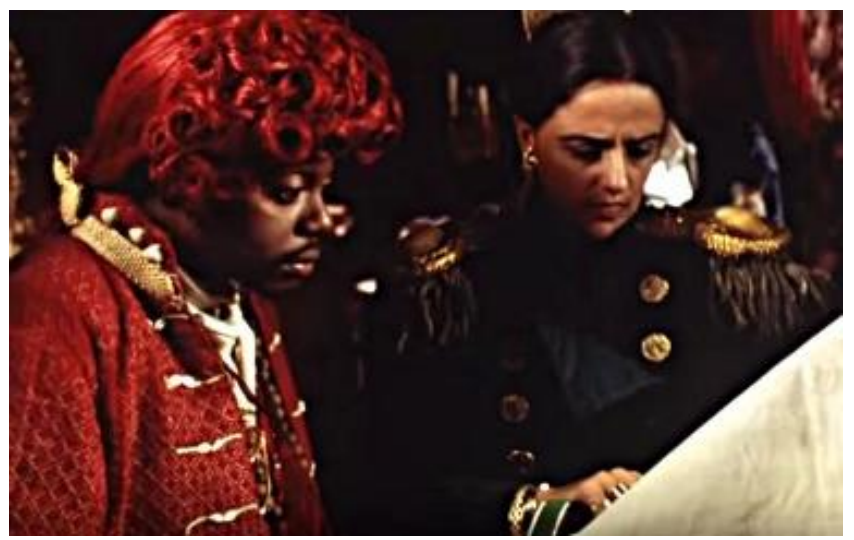

Figura 83 Cena do filme Carlota

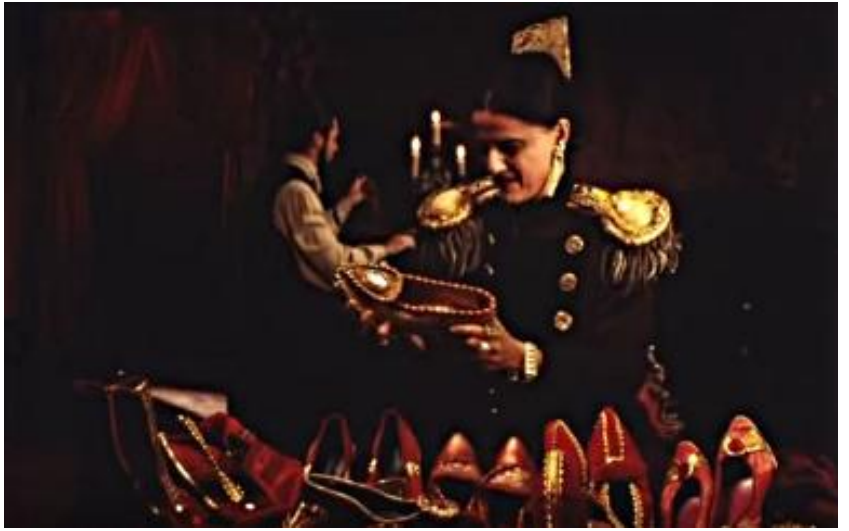

Figura 84 Cena do filme Carlota

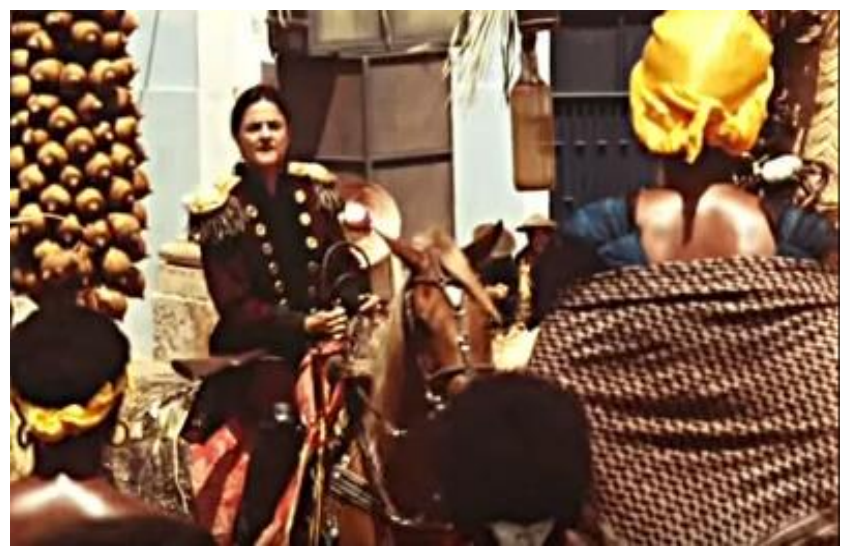

Figura 85 Cena do filme Carlota

A chita entra no vestuário na fase brasileira, como para substituir e referenciar os Gobelin*, seria uma alegoria para o fato da corte ter que renovar seu guarda roupa nas inóspitas condições dos trópicos. O tecido, por ser muito 
fino, foi todo costurado com algodão para dar mais caimento. Os fechamentos eram feitos em pathé (zíper escondido), pela equipe do Teatro Municipal. A ideia

é que a corte, orientada por Carlota, tivesse renovado seu guarda roupa com produtos tropicais, disponíveis no mercado brasileiro

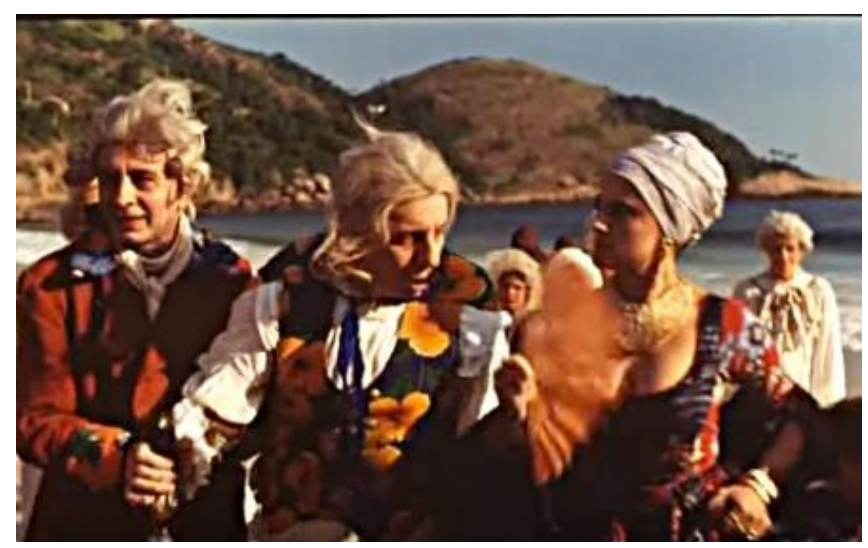

Figura 86 Cena do filme Carlota

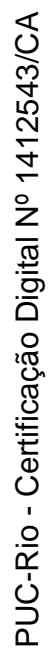

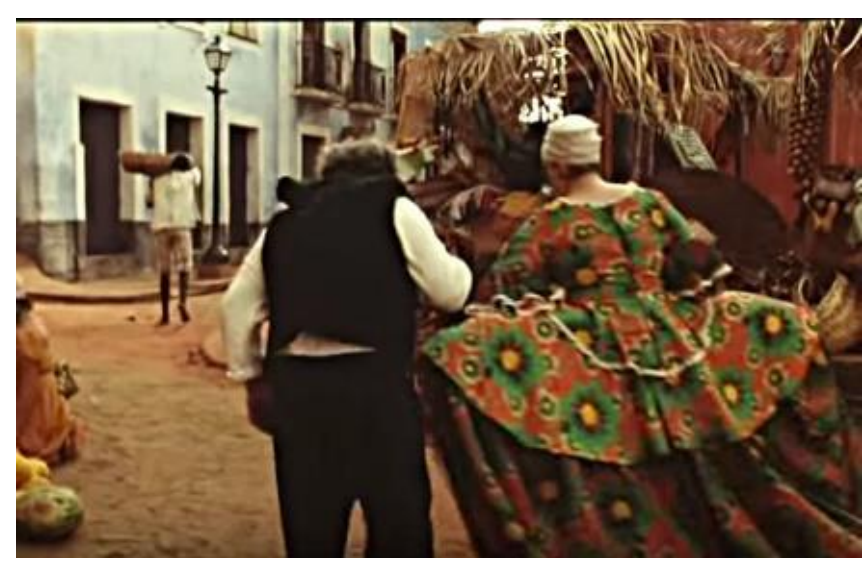

Figura 87 Cena do filme Carlota

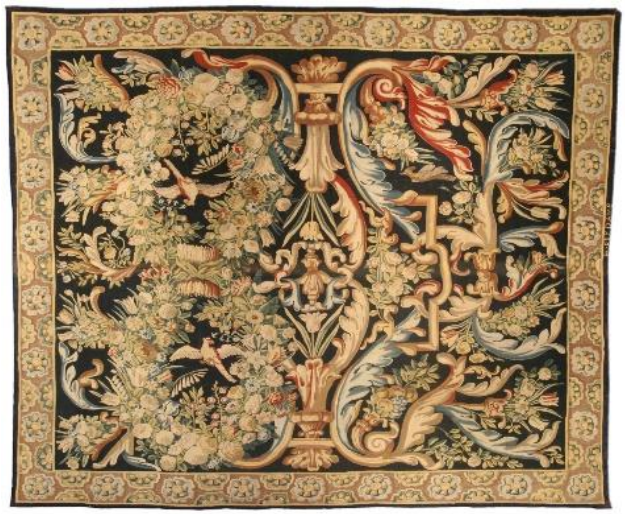

Figura 88 Tapeçaria Gobelin

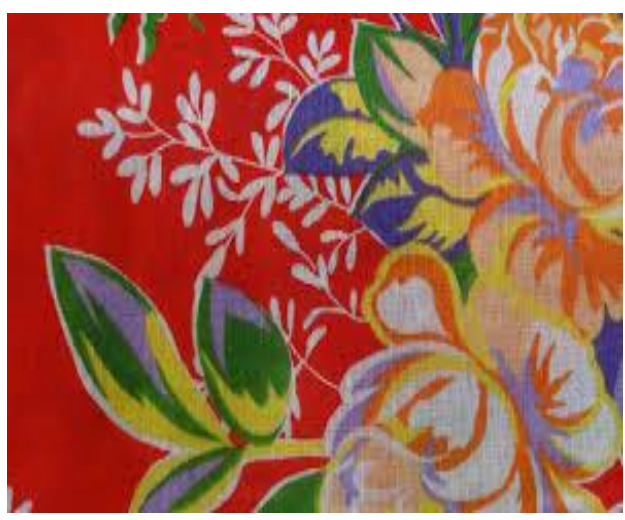

Figura 89 Tecido chita 
D. João VI (Marcos Nanini) usa o verde de Portugal, mas com algumas referências obsoletas, de uma moda anterior (para deixá-lo propositalmente fora de moda). A farda foi feita em pura lã para dar um caimento perfeito (um dos poucos luxos do figurino) e o tom fosco. Botões e passamanarias dourados, trabalhados pela Ana Maria de Morais para que fossem verossímeis, completam a indumentária. As bainhas eram feitas à mão com linha dourada.

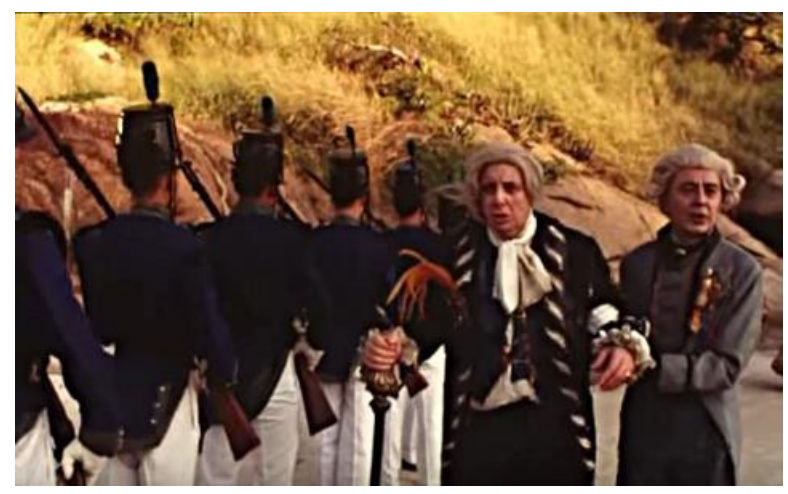

Figura 90 Cena do filme Carlota

D. Pedro I (Marcos Palmeira), na descrição de Emilia, era um moleque da praça $\mathrm{XV}$, que não queria estudar, andava na farra, vivia com as escravas, gostava de esportes e aventura. Juntando essas informações com as imagens de época, os figurinistas decidiram fazer um perfecto (termo usado por Emilia para descrever o jaleco da farda) verde com dragonas que é usado aberto e sem nada por baixo. 


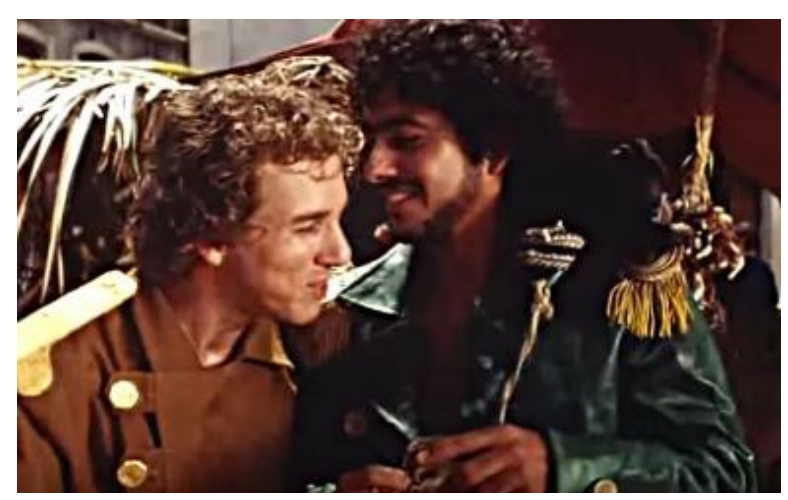

Figura 91 Cena do filme Carlota

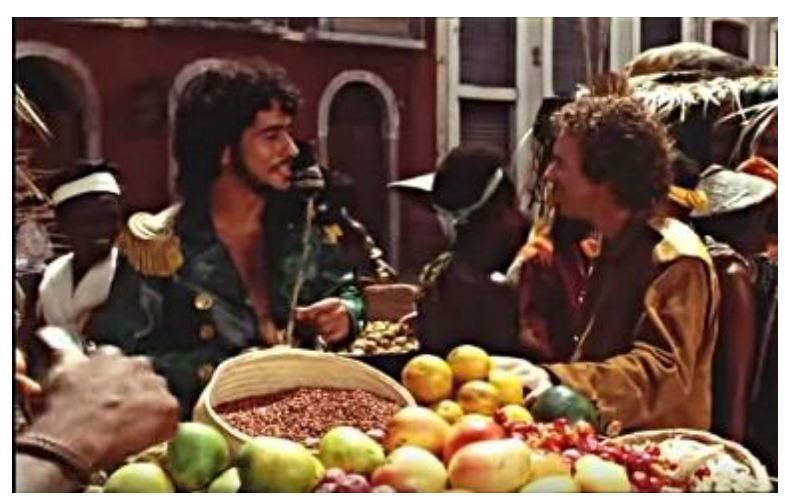

Figura 92 Cena do filme Carlota

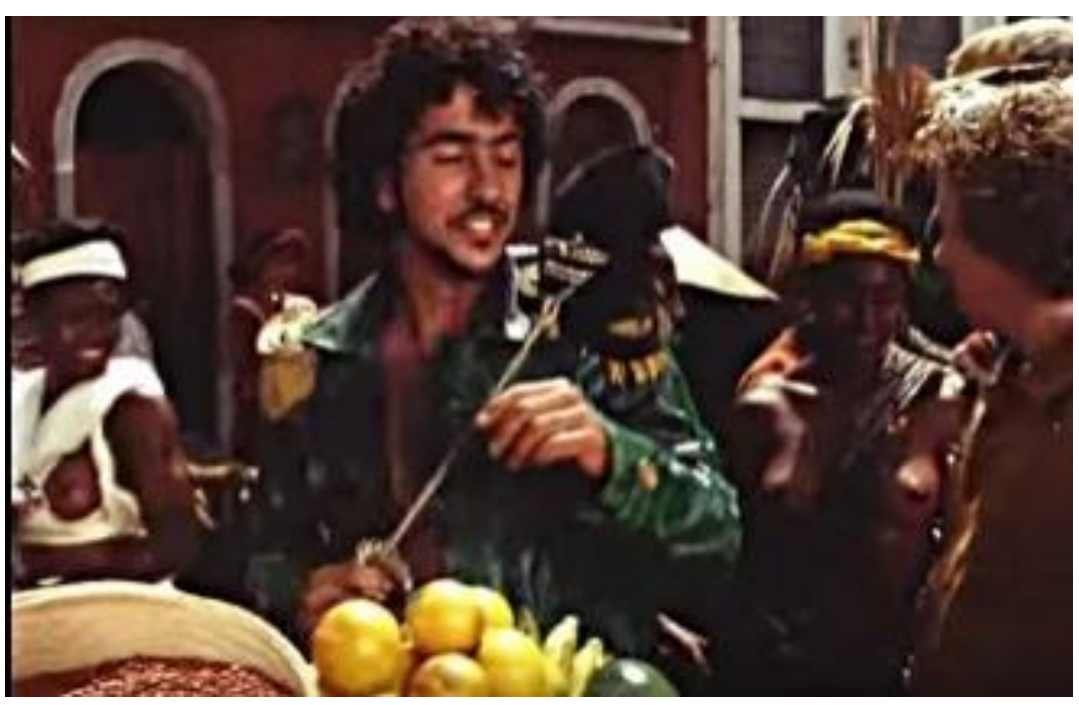

Figura 93 Cena do filme Carlota 


\subsubsection{Produção de Baixo Custo}

O filme se viabilizou em função de uma série de circunstâncias, algumas já mencionadas anteriormente, como tempo e comprometimento dos profissionais envolvidos, mesmo sem verba. Mas é importante citar que, segundo os entrevistados, os apoios e doações foram fundamentais para o projeto. Bem como a criatividade para transformar e reciclar. Os próprios realizadores entraram com seus acervos pessoais, Tadeu doou toda a coleção de chapéus que, devidamente manipulados artesanalmente, viraram as perucas e cabeças para o filme, o acervo do grupo de teatro do qual faziam parte foi reciclado, um tecido da peça As Mil e uma noites, de Karen Acioly (1992) se transformou no vestido de tafetá da mãe de Carlota, Luisa de Parma (foto).

Houve doações de fábricas de tecidos, sapatos e botões, que contribuíram com o que dispunham no momento, independente do elemento histórico. Era necessário todo um trabalho de adaptação: Lycras eram preenchidas com acrylon para mudar de forma e usadas na figuração, a maior parte dos tecidos era tingida ou colocada numa infusão de chá para se adequar à paleta do filme. Os botões foram usados para os mais diversos fins, inclusive nos objetos de cena. Os sapatos, que eram reinventados com detalhes colados e bordados são peça chave do guarda roupa de Carlota e estão presentes no roteiro original "do Brasil, não levo nem o pó! " é a fala de Carlota ao voltar para Portugal e jogar ao mar sua coleção de sapato

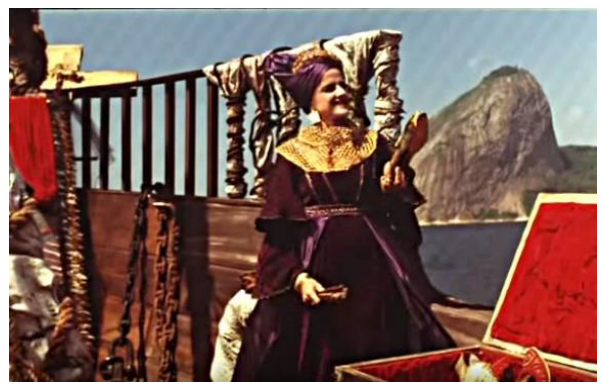

Figura 94 Cena do filme Carlota

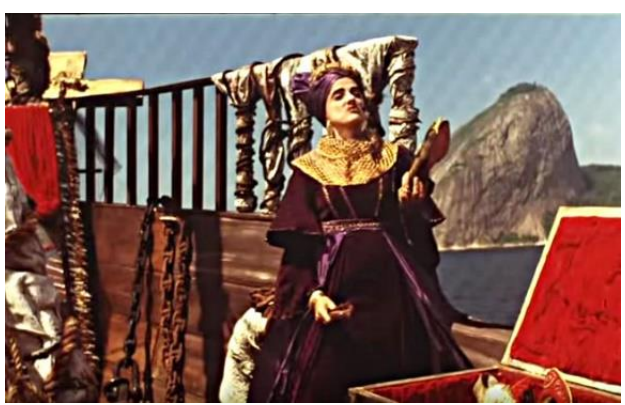

Figura 95 Cena do filme Carlota 
Roupas de dormir foram feitas com as cortinas da casa da diretora, a parte de franzir usada para simular as golas usadas na época.

Há uma cena no filme em que, no mesmo cenário, o figurino branco do casamento (a pedido da diretora) deveria se transformar em preto, pelo luto da morte do cônjuge, como não havia verba para fazer dois figurinos (um branco e um negro), optou-se por construir um figurino com entretela de papel e depois jogar tinta preta sobre ele.

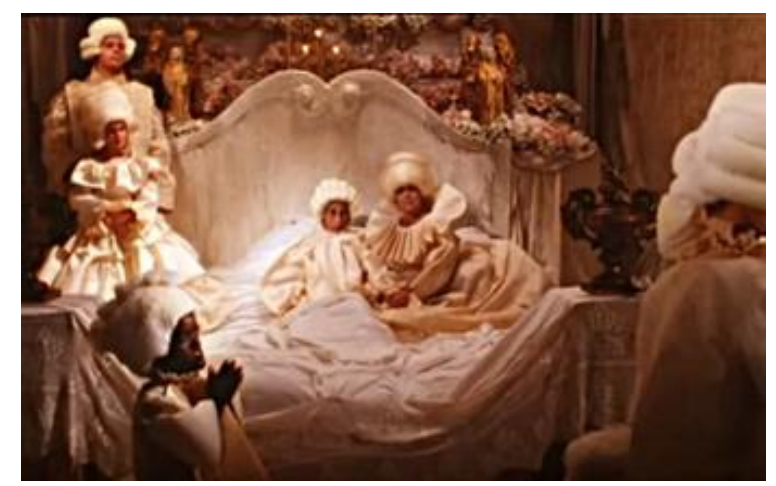

Figura 96 Cena do filme Carlota

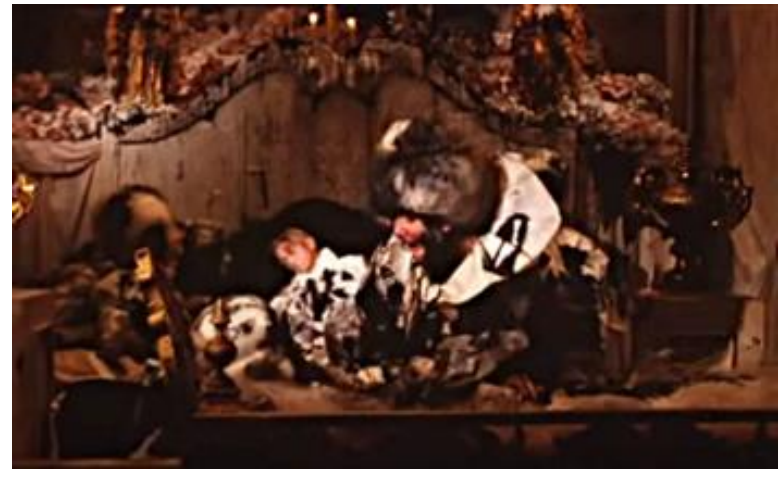

Figura 97 Cena do filme Carlota

Lembrando que, anos depois, Jun Nakao fez um desfile em São Paulo onde todas as roupas são feitas em papel, com alta tecnologia, e rasgadas no final. 


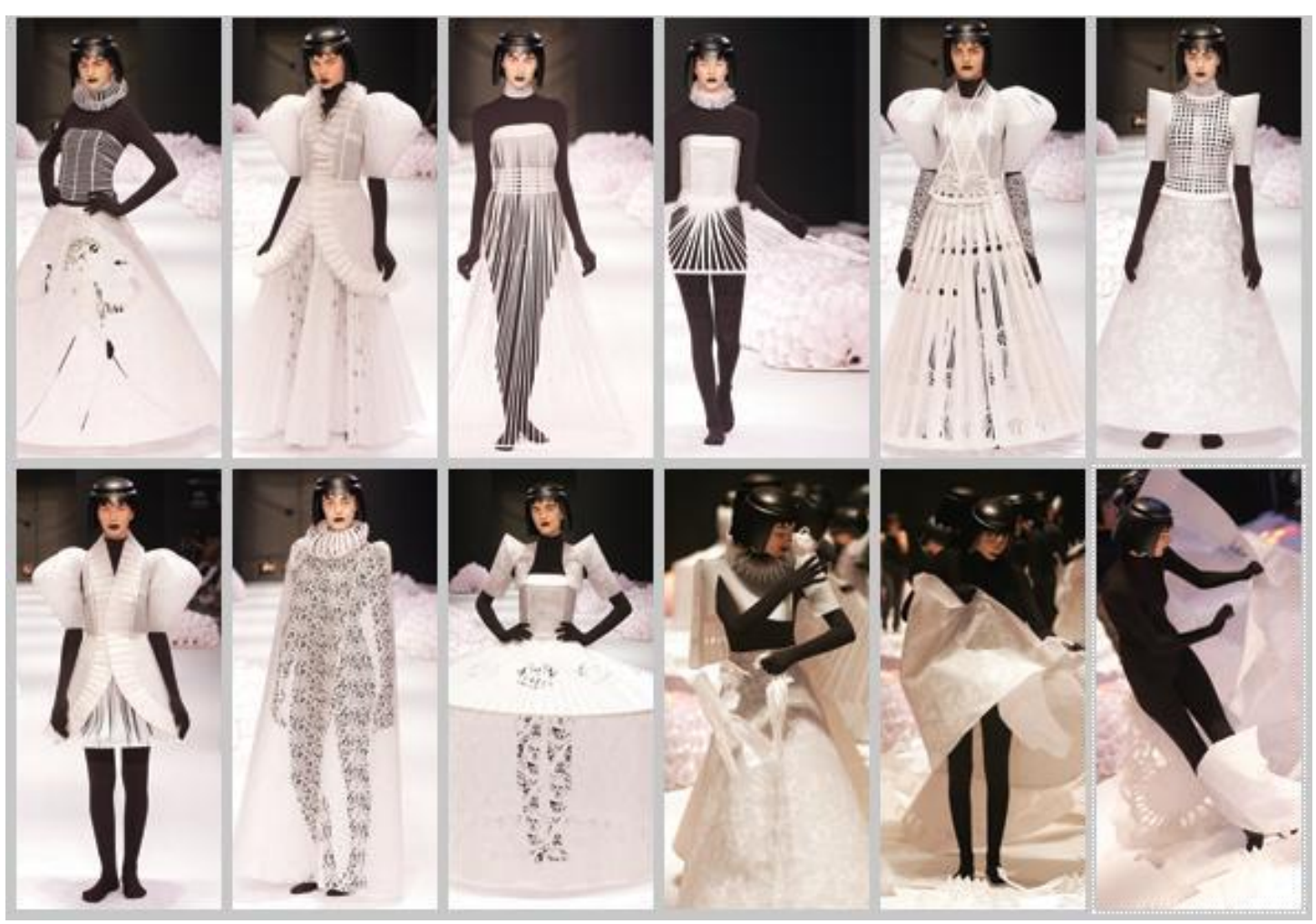

Figura 98 Desfile Jun Nakao ${ }^{22}$

Segundo Marcelo Pies, os acervos de Aluizio Abranches (diretor, produtor e roteirista) e do Teatro Municipal (Inhaúma) foram fundamentais para o elenco de apoio e a figuração.

Marcelo e Emilia dizem ter sido determinante a contribuição dos profissionais (já citados) para o projeto "uma mão de obra que já não existe mais, que viveu os anos de 1940 e 1950, que fazia luvas magistralmente! ”. Toda essa parte do figurino, que Duncan chama de "nobre', como as roupas de Carlota e D. João, foram feitas por esses profissionais sob a administração de Pies.

Para completar, muito envelhecimento, não um envelhecimento naturalista (suor, vivência), mas um envelhecimento de transformação e adaptação dos

22 Em 17 de junho de 2004, no maior evento de moda da América Latina, SPFW (São Paulo Fashion Week), elaboradíssimas roupas construídas em delicado papel eram desfiladas por modelos com perucas playmobil numa performance que simulava um desfile de moda. As roupas foram confeccionadas em papel vegetal de diversas gramaturas e modeladas milimetricamente sobre os corpos das modelos de forma primorosa, filigranas entalhados manualmente reproduziam rendas, gravações em altos e baixos relevos simulavam brocados. Foram consumidas meia tonelada de papel e mais de 700 horas de trabalho.

Ao final todos os vestidos meticulosamente construídos foram destruídos em cena pelas próprias modelos.

A Costura do Invisível recebeu o título de desfile da década pelo SPFW e foi reconhecido como um dos maiores desfiles do Século pelo Museu de Moda da França. É referência nas mais importantes publicações sobre Moda e Design do Mundo e integra acervos Internacionais de Museus de Arte e Moda. www.jumnakao.com/portfolios/a-costura-do-invisivel/ 
materiais disponíveis aos conceitos estéticos do filme. Nas palavras de Duncan "Era a pobreza criativa!".

Burgos dizia que o bom figurino é misterioso, não é de leitura fácil. O olho demora a perceber como foi construído.

Perucas feitas de sisal, adereços de palha para os negros, mesmo os mais sofisticados como o amante de Carlota. Perucas feitas de tule com pedaços de chapéus dos anos 1950 para os nobres. Adereços simples como botões de plástico e passamanarias remodelados e transformados pela artista plástica Ana Maria Moraes em objetos antigos, usando como recursos tinta spray dourada, pó de ouro, tinta de couro e cola. Pequenos recursos somados a muita criatividade para gerar resultados inusitados.

\subsection{Guerra de Canudos}

A imagem interessa não pelo que ela mostra da realidade, mas pelo que ela revela. Esta é a diferença para mim do bom cinema para o cinema medíocre: um revela, o outro mostra. É impossível reconstituir Canudos, que envolveu tanta gente durante tanto tempo, passo a passo. Para contar essa história no cinema, você tem que procurar revelá-la. É uma questão de escolha: que período abranger, através de que personagens. Eu não posso fugir da evidência de que esse tema é perigoso, eu estou mexendo com um assunto que rendeu o maior livro da literatura brasileira, sobre o qual se debruçam milhares de pessoas do mundo todo, é uma ambição e um risco. (REZENDE, apud REZENDE, N., 1997, p.26)

O Filme de 1996, dirigido por Sérgio Rezende e baseado no célebre episódio real da história brasileira, a Guerra de Canudos, na qual o exército republicano, após várias tentativas frustradas, finalmente consegue, de forma sangrenta, dizimar a população insurrecta de 20 mil pessoas, seguidores de Antonio Conselheiro, que haviam construído um território independente, o Arraial de Canudos.

Em duas horas e quarenta minutos, o filme relata a trajetória ficcional de uma família que teria, com exceção da filha mais velha (personagem de Claudia 
Abreu) se juntado a Antônio Conselheiro e seguido com ele até a destruição de Canudos.

Usando como referência o clássico de Euclides da Cunha (Os Sertões), um roteiro escrito por Mário Vargas Llosa para o diretor de cinema Rui Guerra e nunca filmado (e que em 1981 seria lançado como romance sob o título de Guerra do fim do mundo) e muitas pesquisas e referências históricas levantadas pelo diretor, o filme de Rezende ousa uma empreitada de grande porte e orçamento monumental para a realidade brasileira da época.

Este épico nacional, lançado na comemoração do centenário do conflito, com elenco de grandes atores e 5.000 figurantes (seleção oficial Festival de Berlim / PANORAMA) se distancia dos outros dois filmes citados por ser o de maior orçamento: 6 milhões de reais; maior duração: 169 minutos; maior produção e menor público: 600 mil espectadores (maior bilheteria de 1997).

Seis mil peças de roupa, mil e duzentas fardas, quatrocentas camisas, setenta ternos, setenta roupas de couro, duzentos xales, cento e cinquenta chapéus de couro, quatrocentas pares botas. Esses são os números do figurino.

Com direção de arte do então iniciante Claudio Amaral Peixoto, figurinos da já veterana Elizabeth Filipecki e fotografia de Antonio Luis Mendes, Canudos foi a maior produção da retomada.

[...]A Guerra de Canudos talvez tenha sido o mais triste desencontro da nacionalidade já visto na História do Brasil, onde o Estado Republicano literalmente massacrou a segunda maior cidade populosa da Bahia, por conta da insurreição da população local contra o descaso político e social do governo, criando praticamente um Estado paralelo. Essa mancha nas páginas da História Brasileira, tão bem relatada por Euclides da Cunha, com um cunho de literatura sociológica em "Os Sertões", ganha vida na forma de película, com direção de Sérgio Rezende: "Guerra de Canudos. (RUBENS MARTINS NETO www.diaadia.pr.gov.br) 


\subsubsection{O Figurino}

A figurinista Beth Filipecki nos concedeu uma longa entrevista que orientou o texto a seguir. Às informações de Filipecki somamos a entrevista com o diretor Sergio Rezende, o livro Guerra de Canudos o Filme, de Nilza Rezende (Senac, 1997) e pesquisas paralelas e complementares que se misturam no texto. As entrevistas foram na forma de uma conversa informal e ao seu conteúdo foram acrescentadas as informações das pesquisas paralelas (algumas orientadas pelos entrevistados) com a autorização dos mesmos. Em alguns momentos nossos comentários se confundem, propositalmente com os depoimentos editados.

A reconstrução de Canudos foi feita através de pesquisas e das descrições realizadas nos livros, ou das fotografias de Flávio de Barros. Os figurinos do Exército foram conseguidos pela observação nos museus. Quanto às casas, não houve muito mistério, pois, as casas de hoje, neste pedaço de Brasil, estão praticamente como há cem anos: são casas de taipa, cobertas de palha. E como são as pessoas daqui mesmo que construíram, melhor ainda. (REZENDE, em entrevista a autora, 2015)

\subsubsection{Pesquisa Histórica}

Segundo Elizabeth Filipecki, o diretor, Sergio Rezende, já chegou com dois anos de pesquisa na bagagem, o que facilitou muito o trabalho da equipe. "Além disso, quando fui convidada para fazer o filme, eu já possuía um grande conhecimento do tema, sou professora de história e trabalho na rede Globo de televisão há muitos anos, o que me permitiu realizar trabalhos em diversas regiões do Brasil com uma grande estrutura para pesquisa e realização do figurino". Independente dessas facilidades, foi dos filmes que fez, o que mais requisitou pesquisa histórica, segundo a figurinista. Havia muitas fardas, muita figuração de retirantes, a guarda católica que acompanhava Conselheiro de perto, os habitantes das pequenas cidades, as prostitutas. Tudo isso baseado em fatos reais, o que 
pediu uma vasta pesquisa que foi feita, basicamente com fotos de época. "As fotos do Flávio de Barros, fornecidas pelo diretor, foram fundamentais”.

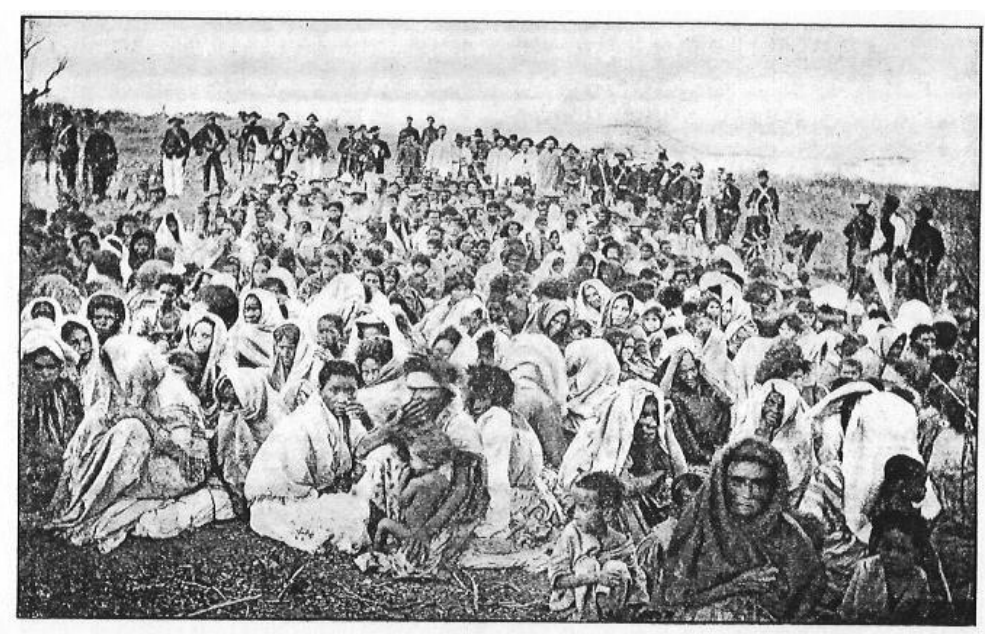

As prisioneiras.

Figura 99 Foto Flavio de Barros

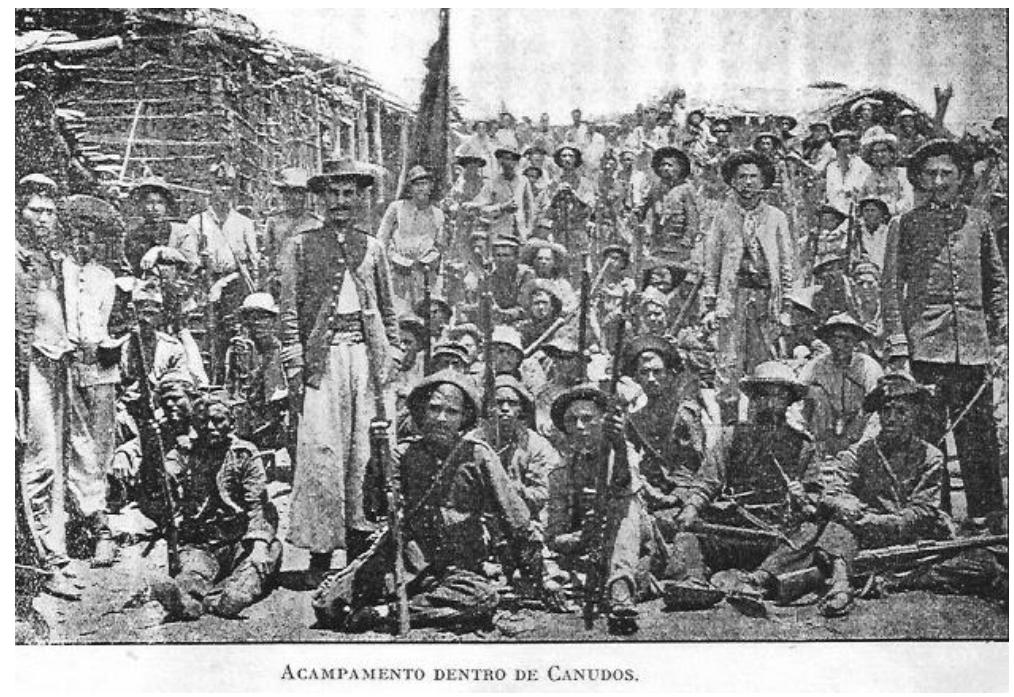

Figura 100 Foto Flavio de Barros

Pelas entrevistas e conversas com o diretor (Rezende), foi possível perceber o envolvimento do mesmo com o projeto (que já vinha de longa data) e suas pesquisas individuais relacionadas ao tema, o que adianta muito o trabalho da arte e do figurino.

O fato do filme ser baseado em um acontecimento histórico, que teve sim o livro (Os Sertões) de Euclides da Cunha como referência, mas também usou muitas outras, pede uma pesquisa maior por parte da direção, mas esta poderia ser terceirizada (o que é muito comum e não foi o caso). 
No caso de $O$ Quatrilho, não tivemos isso. Toda a pesquisa começou com o diretor de arte, Paulo Flaksman e continuou com a figurinista, estando o envolvimento do diretor mais ligado a dramaturgia. É importante ressaltar que neste filme ( $O$ Quatrilho) temos um livro específico como base, um romance, sobre o qual foi escrito o roteiro de Leopoldo Serran. Não existem personagens reais saídos da história, como nos outros dois filmes, o que daria uma maior liberdade de criação. Porém, não foi esta a proposta do diretor; talvez esteja aí a resposta para uma pesquisa tão minuciosa e a fidelidade a ela na realização. Este formato realista gera uma rigidez inevitável para a equipe de criação, o que demonstra, mais uma vez, a proximidade com o design. O figurino, como a direção de arte de um filme, é um trabalho feito por encomenda que precisa seguir precisamente o seu briefing. Quando estamos tratando do cinema brasileiro que se pretende indústria, não existe espaço para maiores devaneios criativos, a menos que tenham sido previamente informados e aprovados como em qualquer indústria de audiovisual.

É importante deixar claro aqui que não pretendemos qualquer crítica a indústria audiovisual, ao contrário, a retomada conseguiu alçar o cinema nacional na conquista deste status. O que queremos esclarecer é que, dentro do cinema profissional, as áreas (fotografia, arte, figurino, montagem) devem seguir uma proposta de linguagem estabelecida pelo diretor (no caso do Brasil). No Brasil, como na Europa, temos um cinema de diretor (autoral) diferentemente do modelo industrial americano de cinema de produtor. As maiores produtoras brasileiras são familiares, historicamente. Isso dá ao nosso cinema um simpático e aprazível nepotismo. O cinema brasileiro sobreviveu durante anos graças a uma estrutura familiar, quase caseira e apaixonada e que agora, está se abrindo e se expandindo. O novo cinema independente e as antigas produtoras, após a retomada, se namoram e geram frutos pelo mundo, em várias línguas e várias mídias.

\subsubsection{A Cor}

"Em Canudos, as pessoas são da cor das casas, a cidade é da cor da caatinga, a caatinga é da cor da terra, e o figurino se integra com tudo isso" REZENDE 
"Saber usar a cor emocionalmente é um grande trunfo, a cor é um vínculo emocional com o espectador"

FILIPECKI

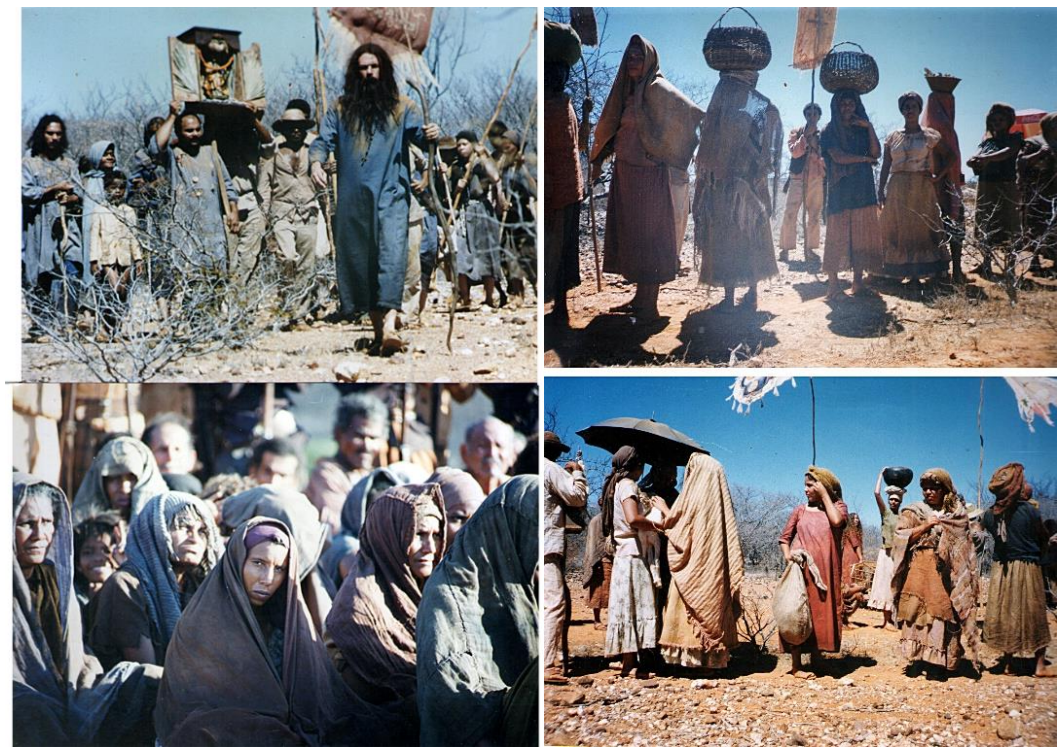

Figura 101 Cenas do filme Canudos

Observamos no figurino do filme um contraponto entre os tons terrosos para a maioria do povo e dos azuis para a guarda católica e todos aqueles que estão mais próximos de Conselheiro, Filipecki disse que isso é muito pertinente e está no livro do Euclides (Os Sertões). Há, inclusive, uma fala do Conselheiro no filme que diz que o azul de suas vestes é uma referência ao manto de Nossa Senhora. Existe realmente uma questão conceitual que é corroborada por evidências reais. "Sempre tive uma preocupação com a cor local e de como passar essa cor para o traje"

A separação entre terreno e divino representada pela cor está, claro, presente no filme quando são trabalhados os terras e os azuis. A terra existe, o céu que é azul, é o sublime, o inalcançável. Mas há, também, um elemento real que influi nessas cores. O barro e as areias do cenário nordestino do sertão baiano impregnam no algodão natural das vestimentas e o azul, tingimento chamado de índigo ou anil e adquirido através das folhas da Indigueira (Indigofera Suffruticosa Mill), era o mais acessível no nordeste brasileiro. 


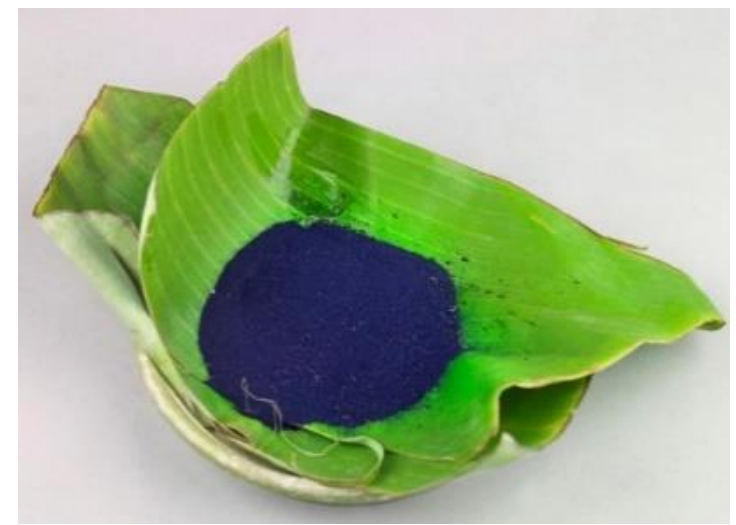

Figura 102 Indigueira (Indigofera Suffruticosa Mill)

No filme, o tingimento não foi feito com os produtos originais levantados na pesquisa (índigo), o que seria extremamente complicado logisticamente. Foram utilizados os pigmentos disponíveis no mercado brasileiro para coloração de tecidos que responderam perfeitamente às expectativas, pelo fato de terem menos durabilidade, serem mais sensíveis às lavagens e à luz do sol, desbotando mais rápido que os pigmentos importados, o que favorecia o trabalho de envelhecimento.

As fardas até o final do século XIX tinham cores vibrantes, botões e adereços dourados, inspiradas nas referências europeias. A maior preocupação era a demonstração de poder e não a camuflagem, que só surgiria no século XX.

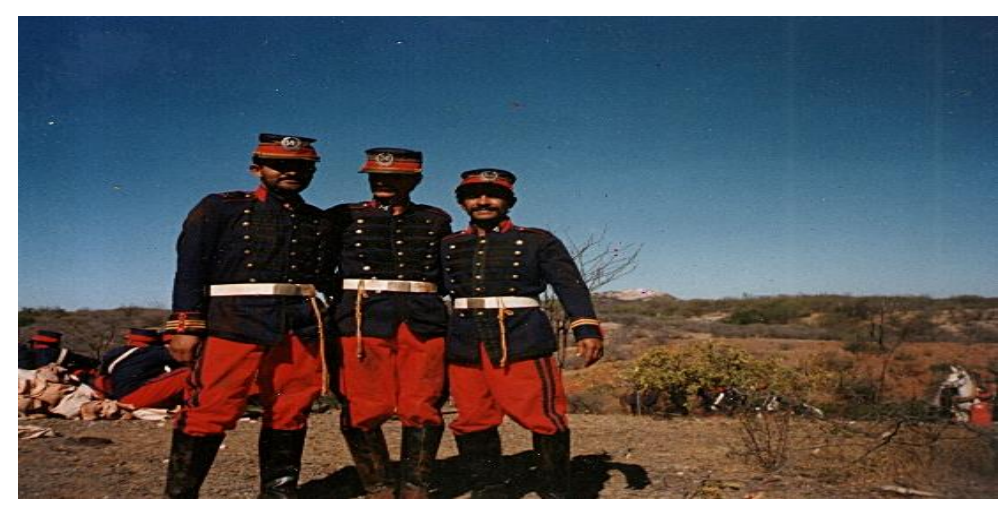

Figura 103 Cena do filme Canudos 
Imitando o padrão europeu, as fardas da república, com suas calças vermelhas, jalecos azuis e botões dourados, eram praticamente um alvo no meio do sertão terracota onde o inimigo se confundia com a paisagem cor de terra.

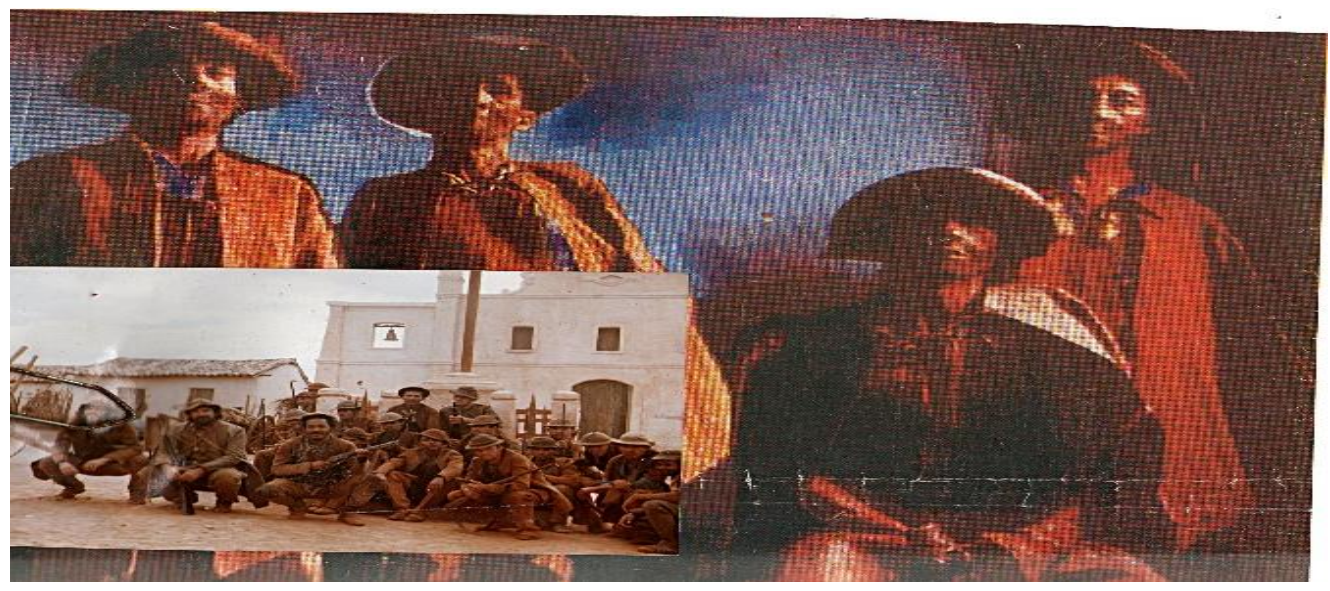

Figura 104 Cena do filme Canudos com referência

Como havia muito tiroteio, as fardas estavam sempre sendo remendadas. Havia um ateliê com senhoras locais, não havia várias roupas para cada figurante, então a manutenção era necessária. Muitas vezes os próprios figurantes remendavam e restauravam suas roupas, inclusive colocando elementos pessoais, personalizando e humanizando a indumentária

\subsubsection{Logística}

Todo o figurino do filme foi confeccionado, nada foi comprado (com exceção das roupas de couro, encomendadas em Feira de Santana, que tiveram que ser recosturadas com linha de algodão. "No caso das roupas de couro, típicas dos cangaceiros, começamos por uma modelagem de referência histórica e produzimos algumas peças no Rio de Janeiro, baseadas em imagens fotográficas. Aí percebemos que essa modelagem não funcionava na prática. Partimos para a pesquisa de campo e descobrimos que as roupas de cangaceiros produzidas hoje em dia e encontradas nos mercados, pouco diferem daquelas de cem anos atrás. As roupas de couro foram compradas na Bahia e foi contratado um ateliê para trocar as linhas de nylon por linha natural de algodão". Um filme de grande porte 
e grande orçamento, mas que carecia de uma produção artesanal para obter o resultado desejado.

Aqui temos um ponto em comum entre os três filmes: figurinos confeccionados especificamente para o projeto. Mesmo que em alguns casos (como Carlota) houvesse reaproveitamento de materiais, ou de roupas doadas por acervos, eles foram totalmente transformados em ateliers. Não houve aluguéis de roupas prontas em acervos, ou grandes lojas, como a Angels de Londres, o que eventualmente, ocorre em produções mais recentes e com recursos. "Optei, ao contrário do diretor de arte, por produzir todo o meu figurino no Rio de Janeiro. Além de problemas pessoais de agenda que me impediam de ficar um período muito longo fora da cidade, havia toda uma infraestrutura da qual eu dispunha e que facilitaram muito a logística".

Foi montada uma oficina em Botafogo, no Rio de Janeiro onde catorze profissionais trabalharam por quatro meses, de lá saíram duas mil peças de roupa. Filipecki trabalhou, também, com seus alunos da Faculdade de Teatro e Belas Artes da Uni-Rio que criaram xales, lenços e acessórios.

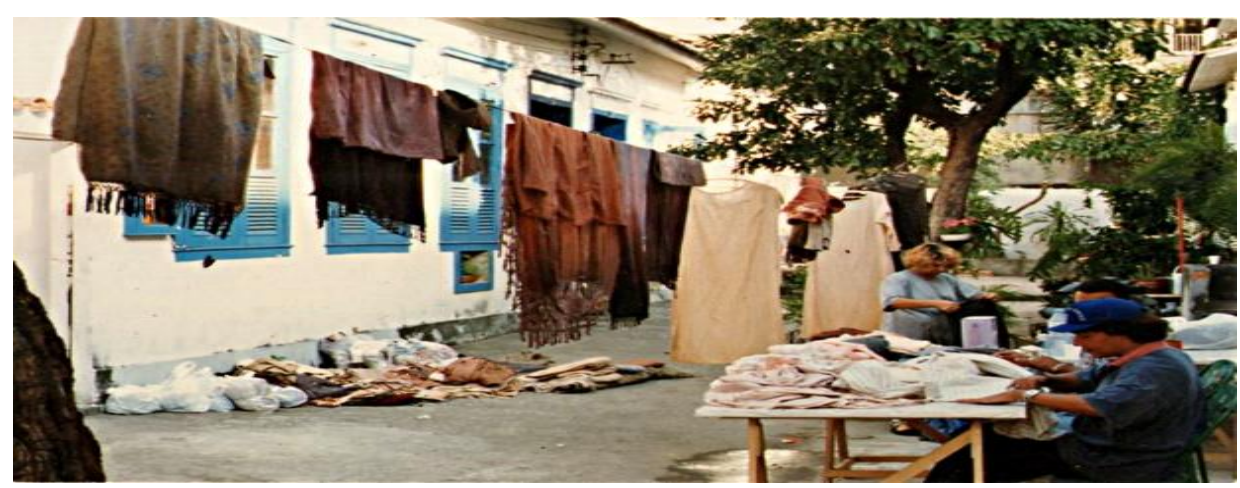

Figura 105 Ateliê no Rio de Janeiro

As fardas da república foram produzidas pelo SENAI CETIQT, em cima de modelos emprestados pelo Museu Histórico Nacional e depois trabalhadas com esmeril para envelhecer. Foram utilizados cinco mil metros de brim e trinta e dois mil botões. A estrutura e o corte em máquinas industriais permitiram a entrega do figurino a tempo do início das filmagens.

Todo esse material foi embalado em trezentos sacos de cem quilos que precisaram de dois caminhões para serem transportados do Rio a Juazeiro. 

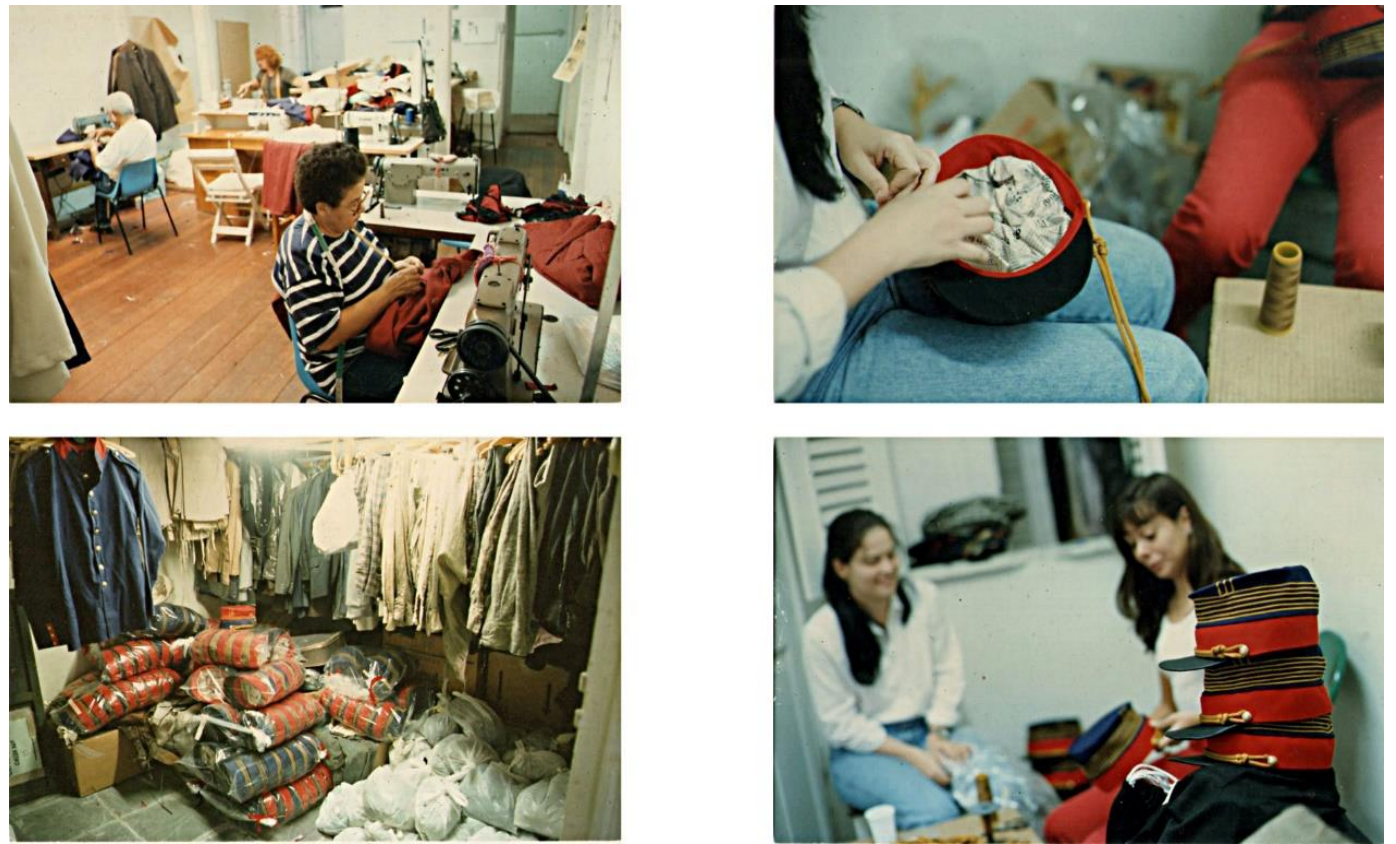

Figura 106 Ateliê no Rio de Janeiro

\subsubsection{Materiais e Envelhecimento}

"As aulas que tive de "têxteis" com Almir Paredes Cunha, diretor da Escola de Belas Artes de 1976 a 1980, foram fundamentais para o conhecimento de materiais e técnicas de envelhecimento que tanto me valeram no filme."

Foi usado, basicamente, algodão produzido em teares $(\mathrm{com} 90 \mathrm{~cm}$ de largura), uma malha tubular, utilizada na embalagem de tecidos, que a figurinista já conhecia de trabalhos anteriores e é um material muito versátil; além das cambraias antigas recebidas de doações. Tudo costurado à mão e tingido com pigmento Guarany (facilmente encontrado no mercado brasileiro). 


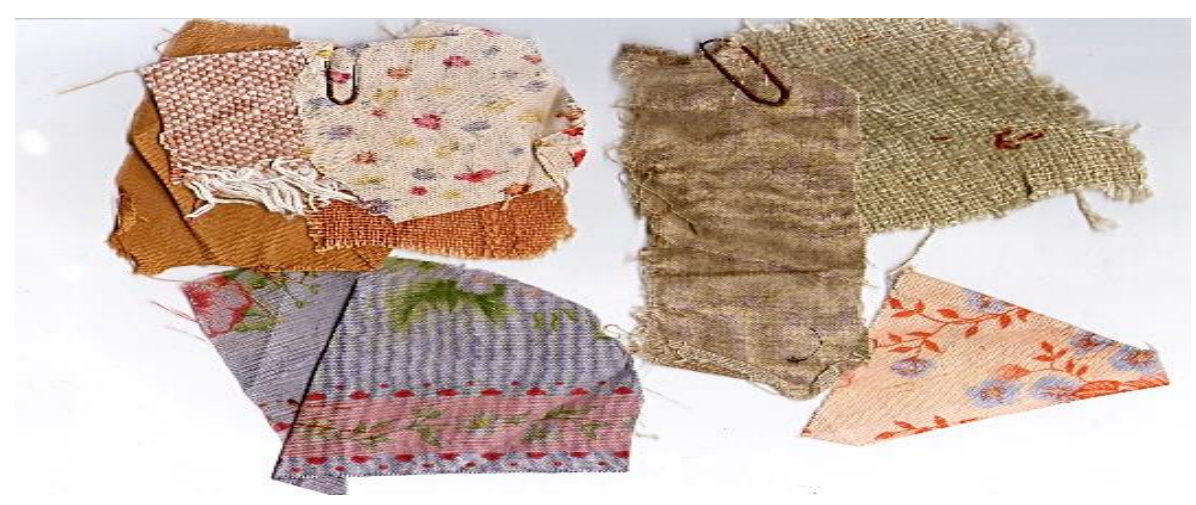

Figura 107 Tecidos acervo Filipecki
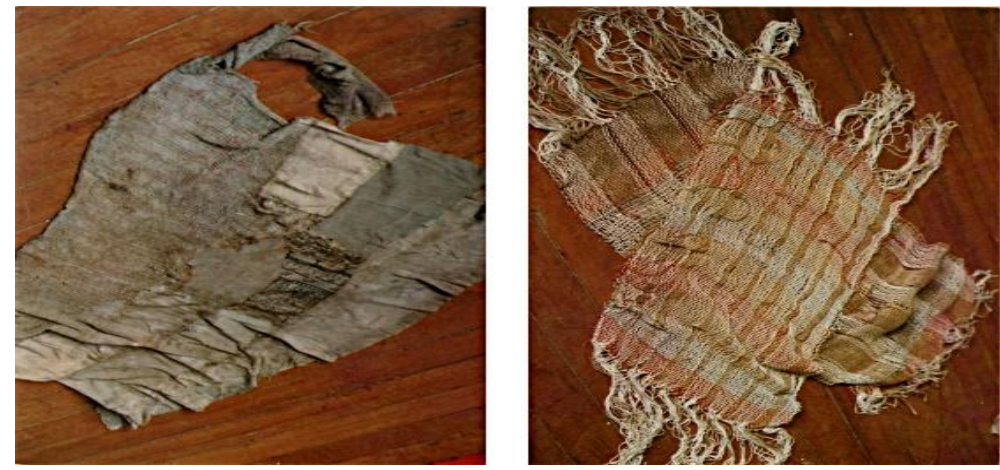

Figura 108 Tecidos acervo Filipecki

Usou-se, também, tecido de cama e mesa, como lençóis e toalhas de mesa pela vantagem da largura e pelas estampas florais miúdas, muito comuns e muito queridas no nordeste brasileiro.

Para as amarrações dos xales, lenços e turbantes houve a assessoria de uma especialista de Salvador.

As roupas quase não tinham modelagem, era um formato saco, corte reto franzido com cadarço.

Nós figurinistas sabemos que um dos elementos de peso no resultado final de um figurino, seja ele de época ou não, é o que chamamos de vivência. Exceto em filmes publicitários ou em trabalhos que remetam ao glamour ou à moda, a veracidade de um figurino depende muito da vivência e isso se dá através do envelhecimento das peças. Se observarmos pessoas na rua ou em casa, não veremos roupas novas como se tivessem saído das lojas. Como na ficção tudo 
deve ser feito de forma superlativa para que se tenha maior credibilidade, o trabalho de envelhecimento e vivência é fundamental no figurino.

No caso de um filme como Canudos, essa questão se torna fundamental, dada a construção histórica. Aquelas pessoas provavelmente possuíam uma única roupa, que vai envelhecendo naturalmente com o passar do tempo.

Além disso, estamos no meio de uma guerra, com tiros, batalhas corpo a corpo, vigílias no descampado. Filipecki diz que tudo isso criava uma situação em que as roupas se deterioravam no próprio processo de filmagem, sendo necessários restauros como remendos e novas costuras que contribuíam para a veracidade do produto final. "Para simular a sujeira de cena uso uma mistura de óleo sem cheiro, cera neutra, tinta (pó xadrez) e amaciante de roupas que, espalhada nos figurinos, cria uma camada encardida".

$\mathrm{Na}$ chegada ao Nordeste com todo material já envelhecido no Rio de Janeiro, a figurinista constatou que, sob aquele sol ardente tudo parecia novo e teria que ser retrabalhado. Foi montado um ateliê com cerzideiras e bordadeiras da região que lavavam, envelheciam e remendavam as roupas. As próprias mulheres da figuração, já sentindo a indumentária como sua, pediam para levar para casa, lavar e remendar. Isso fazia com que a cada vez a roupa ficasse mais orgânica, mais interessante, era resto de roupa, contava melhor a história desse povo.

\subsubsection{Referências e Bagagem}

Além da referência e influência dos grandes mestres, brasileiros e estrangeiros, o conhecimento de história da arte e da heráldica, do significado das cores em cada época e circunstância, estão presentes no trabalho da figurinista. 


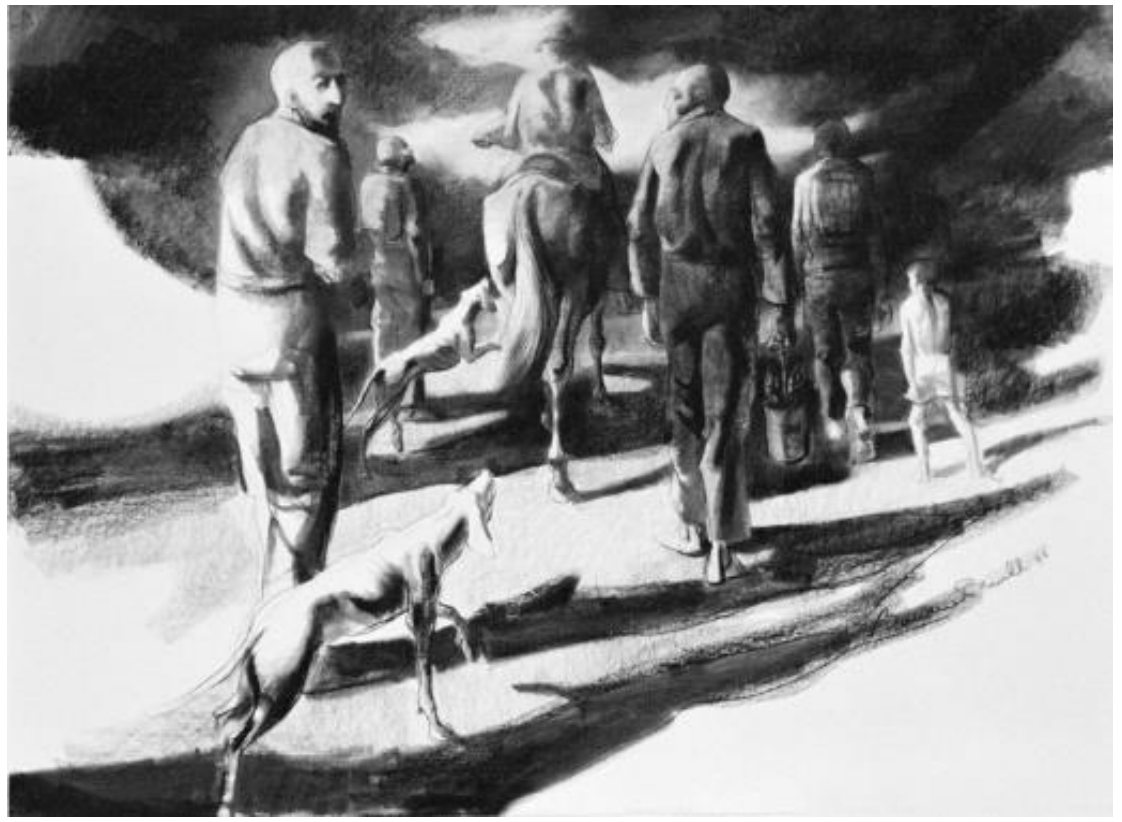

Figura 109 Quadro Bandeira de Mello

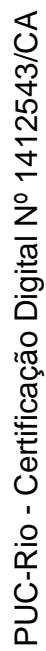

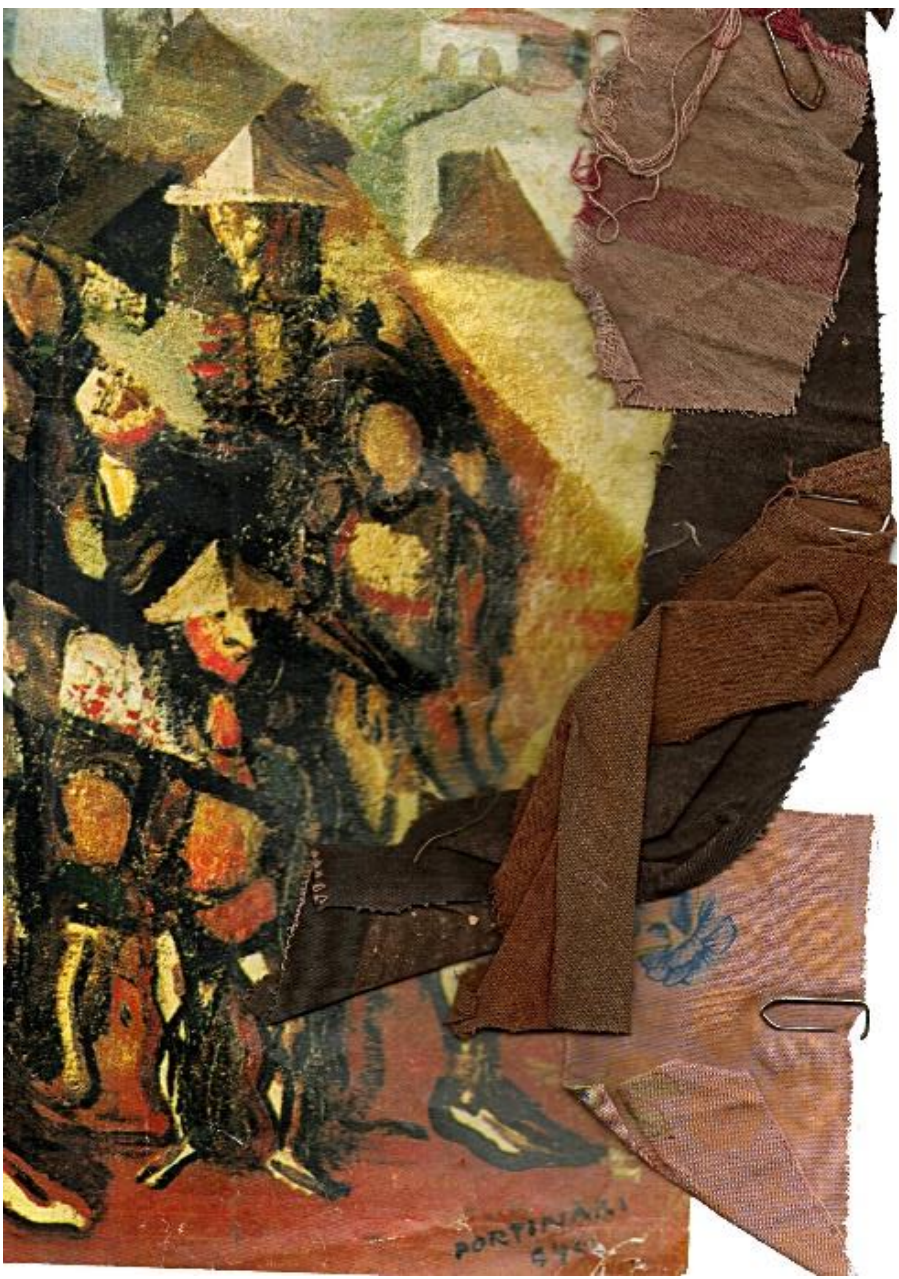

Figura 110 Quadro Portinari com tecidos de referência 
A vivência das óperas e balés, dos grandes espaços cênicos ajudou muito, segundo Filipecki, além dos grandes mestres como o Lydio Bandeira de Mello, Adir Botelho, Almir Paredes Kalma Murtinho, Maria Augusta Rodrigues, e Hélio Eichbauer [...] "que trouxeram a reflexão da prática profissional embasada nos estudos clássicos da história da arte e da cultura ocidental. Apliquei muitos conhecimentos recebidos, buscando uma analogia simbólica nas paletas dos artistas escolhidos com a religiosidade e o caráter trágico da guerra"

Nas referências pictóricas são citados, basicamente, El Greco, Portinari e Goya, principalmente as fases negras, que, somando o fotógrafo Sebastião Salgado, completam a inspiração dos figurinos. Segundo a autora dos figurinos, os mestres citados elaboraram seus fazeres em um fundamento humanista, que só existe no universo da arte, e é justificada pelo fato de serem artistas que trabalham o desespero da guerra, a religiosidade e o camponês.

"Não posso me esquecer do apoio logístico do Núcleo do Sertão da Universidade da Bahia, liderado pelo professor José Calazans.”

\subsubsection{Figuração}

Eu gosto de trabalhar a figuração como um coro.

FILIPECKI

Canudos. 20 mil pessoas mortas: 5 mil soldados - quase dez vezes mais a população que habitava Juazeiro, a maior cidade do norte da Bahia na época. Uma guerra que se fez no corpo-a-corpo. Gente contra gente. Para reviver este conflito, Guerra de Canudos precisava encontrar essa gente, pessoas que se assemelhassem àquelas de cem anos atrás. (REZENDE, N.,1997, P.113)

Segundo Jurandir de Oliveira, ator e preparador de elenco, sua equipe chegou a Bahia com três meses de antecedência e começou a anunciar o filme em Juazeiro e Petrolina, nas rádios, festas e vaquejadas para convocar pessoal para a figuração. No início houve grande desconfiança e resistência, mas aos poucos e de porta em porta, 4 mil figurantes foram listados.

Eles tinham que ter a cara exata do sertão. O sofrimento, a cor da terra, a pele enrugada do sol, o olhar do sertanejo, que parece não ter expressão, um olhar apagado, como quem olha para o horizonte perdido. (OLIVEIRA, apud, REZENDE, N.,1997, P.113) 
A figuração foi dividida em grupos, o que facilitou tanto o trabalho da direção como do figurino e da arte, pois cada grupo possuía sua paleta de cor e suas referências pictóricas. Havia o grupo das beatas e apóstolos, o grupo dos deficientes físicos e mutilados. Trezentos e cinquenta militares do Batalhão de Infantaria de Petrolina e duzentos soldados da Policia Militar da Bahia compuseram o grosso da figuração militar do filme.

É a imagem mais forte que eu levo do filme, o povo de Canudos.

(WILKER, apud REZENDE, N.,1997, p.114)

Nosso olhar deveria recair sobre o ser humano, o sertanejo como uma metáfora do homem eterno; esse homem que, passadas gerações e gerações, mantinha o elo com a vida, O herói sertanejo é o herói da Idade Média - ser tão, ser inteiro, apesar do sofrimento. (FILIPECKI, em entrevista a autora, 2015)

\subsubsection{Tecnologia}

Dos três filmes analisados o único a utilizar a tecnologia do computador para auxiliar a elaboração dos figurinos foi Canudos, Filipecki selecionou e digitalizou as pinturas e o material de referência para elaborar uma paleta cromática do figurino, utilizando recursos recém-chegados ao Brasil, graças ao apoio do SENAI CETIQT, onde ela lecionou "Indumentária brasileira" no primeiro curso de Estilismo de ensino médio. O sistema LECTRA além de digitalizar os moldes das fardas oferece ao designer uma ferramenta de criação que se estende na busca e apropriações de possibilidades criativas. Ali desenvolveu um projeto. Cada personagem do filme mereceu estudos no computador. A partir das imagens digitalizadas, eram sobrepostas a fotografia do ator uma sugestão de figurino para a personagem, o que permitiu fazer experiências visuais e verificar imediatamente o resultado delas, vislumbrando concepções possíveis para o figurino do filme. 


\section{DESENHANDO CINEMA, projetando figurino}

\section{Design e cinema na construção de uma identidade visual}

O fio usado para tecer o projeto de construção de um figurino é fiado na roca do design com a fibra do cinema. O resultado dessa urdidura é chamado de costume design.

Este capítulo usa a tese de doutorado de Vera Bungarten (A imagem cinematográfica: convergências entre design e cinema, 2013) como principal referência para relacionar Cinema e Design e embasar a ligação do trabalho do figurinista (costume designer) ao trabalho do designer.

O termo "desenhar um filme" foi usado pelo diretor de arte Marcos Flaksman, um dos mais antigos profissionais brasileiros ainda atuantes em cinema e outras mídias, para nomear uma exposição sua realizada em 2009. Porém, podemos estender o termo muito além dessa cunhagem, até Holywood e seu Oscar, já mudaram o termo "melhor direção de arte" para "melhor desenho de produção (production design). Como dissemos em nossa introdução, o processo e o projeto de um figurino passam por um traçado muito semelhante ao do designer, ao criar um objeto, seja ele um cartaz ou uma marca.

Em design, chamamos de identidade visual o conjunto de elementos formais que representa, visualmente, um nome, uma ideia, um produto, uma instituição. O processo de criação dessa identidade passa por um briefing (conceito, ideia geral) fornecido pelo cliente, depois vêm as reuniões de criação (estamos falando das produções em equipe, como no cinema), que geram um processo que começa com a elaboração de um desenho de projeto e culmina com a concretização de um produto final.

Aqui podemos fazer uma analogia com o processo de criação e construção de um figurino. Nosso briefing é o roteiro, quando se estabelece um desenho geral de cada personagem. Nossas reuniões se dão com o diretor, o ator (construção da personagem), o diretor de fotografia (cor e materiais, refração etc.), produção (custos e viabilidade dos materiais utilizados, cronograma de produção), a partir daí partimos para um desenho de projeto que irá culminar com o produto final: o filme. 
O termo Design se traduz frequentemente como projeto, o que não elimina a palavra desenho ou desenho de projeto.

\subsection{O molde do Design}

Em inglês, a palavra design funciona como substantivo e também como verbo (circunstância que caracteriza muito bem o espírito da língua inglesa). Como substantivo, significa, entre outras coisas, "propósito", plano", "intenção", "meta", "esquema maligno", "conspiração", "forma", "estrutura básica", e todos esses e outros significados estão relacionados a "astúcia" e a "fraude". Na situação de verbo - to design- significa, entre outras coisas, "tramar algo", "simular", "projetar", "esquematizar", "configurar", "proceder de modo estratégico". (FLUSSER, 2007, p. 180)

Design (to design) do latim "designare" (de + signum) significa desenvolver, conceber. A expressão surgiu no século XVII, na Inglaterra, como tradução do termo italiano "disegno", mas somente com o início do progresso da produção industrial e com a criação das "Schools of Design", é que essa expressão, acompanhada dos atributos "industrial" ou "graphic" passou a caracterizar uma atividade específica no processo de planejamento e desenvolvimento de objetos de uso e sistemas de comunicação visual. Na Inglaterra, onde a expressão teve origem, "design", significa genericamente "planejamento" e é associado a diversas atividades como engenharia, eletrônica, arquitetura, etc. Nos dias atuais, "industrial design" vale como conceito internacional para desenho industrial (português, no Brasil), "industrielle Formgebung" (alemão), "esthétique industrielle" (francês), "diseño industrial" (espanhol), "technitscheskaya Estetika" (russo) etc. (BOMFIM, 2001, p.7)

A palavra "design" é muito rica. Segundo Gomes (1993), o termo inglês "design", além de significar "desenhar" e "desenho", denota também, uma grande área do conhecimento humano que se responsabiliza por arranjar, organizar, classificar, planejar, projetar e, especificamente, desenhar artefatos, mensagens, ambientes ou espaços para a produção industrial ou artesanal. (COUTO, 1997, p.1)

Dentre os três conceitos sobre design mencionados acima, o que nos parece mais adequado à abordagem do presente projeto de dissertação é aquele que define a faceta falsificadora e astuciosa do designer. Ele está muito presente em Flusser (2007), mas é mencionado também por Forty (1983) e está relacionado à capacidade do designer de construir uma versão mais crível e palatável para os objetos industriais, muito mais do que a ideia original que inspirou o designer a projetar aquilo que projetou. Ocorre que isso que normalmente chamamos de "ideia original" não é outra coisa senão um recurso dissimulador habilmente 
empregado pelo designer para aumentar as vendas dos produtos projetados. Julgamos, antes de avançarmos, que é necessário definir o objeto industrial dentro do contexto histórico em que ele está situado, daí partimos do princípio de que ele deve ser visto como mercadoria e não apenas como um objeto funcional. E seja essa funcionalidade uma dimensão utilitária, ou seja apenas uma roupagem estética, ambas operam a transformação do objeto industrial em mercadoria, isto é, algo para ser consumido e produzir mais valias para quem o produziu. Essas noções servem tanto para vender uma versão "inovadora" de um objeto de uso cotidiano como um copo, uma cadeira, ou um espanador, como também, no caso do cinema, para convencer espectadores das belíssimas reproduções imagéticas de uma determinada época que ele está vendo na tela do cinema, como também para revisitar e reconstruir um corpo histórico.

Comecemos pela visão de Flusser sobre o termo design e sua conotação de engodo, falsidade, astúcia nada teria de negativo. Flusser vê desta forma quem considera a maestria do prestidigitador, do mágico, do cineasta e de outros que brincam com a realidade como algo pejorativo ou menor. Talvez essa forma de ver de Flusser seja um tanto ou quanto pejorativa, mas é preciso atentar que o sentido que ele dá ao design, como trapacear com a realidade na verdade trata-se de uma grande habilidade para construir um real mais perfeitamente crível do que seu original, tal como fazem o cinema e a literatura.Enfim, Flusser pensa que a prática do designer é semelhante a prática do figurinista, que reinventa um real, por ele imaginado e o reconstrói na tela. Um jogo de cena.

No caso do design estaria sendo operada a mesma ação de burla que normalmente os técnicos de cinema empregam quando desenham, pintam ou esculpem, produzem alguma coisa que não é palpável (o cinema é uma imagem bidimensional), mas muito próxima ou verossímil ao real, exatamente quando eles tentam "vender gato por lebre". Se o projetista for bem-sucedido no seu projeto de design, significa que ele é um bom profissional e fez um bom trabalho, independente de juízos morais. Esses cabem à outra alçada. Do mesmo modo, quando lemos um livro como Robson Crusoé, sabemos que aquilo é fantasia do autor e o mesmo se dá quando assistimos um filme de ficção científica. Todo mundo que está sentado na sala de cinema sabe a priori que aquilo que está acontecendo na tela é fantasia. Porém, quanto melhor for o engodo (se essa for a proposta) mais bem-sucedido serão o criador e o espectador. 
Cabe aqui deixar claro que ao utilizar o termo "arte" neste contexto, estamos oferecendo uma conotação corriqueira do termo e da prática do "artista" que é dada àqueles que brincam com a realidade e não ao conceito de "produção artística" ou "obra de arte" tradicional. Como veremos mais adiante, entendemos essa farsa do designer como alguma coisa diferenciada da noção tradicional de arte. Essa capacidade de "mentir" ou falsear com a realidade, típica dos profissionais que no Brasil são conhecidos como figurinistas e diretores de arte (e que nos EUA recebem títulos talvez mais adequados de costume designers e production designers) está muito mais próxima da função do designer como seguidor de um briefing e da definição prévia de um público alvo para a criação de seu produto, muito mais real do que parece ser.

Tal como menciona Forty, design e arte não podem ser confundidos. O nosso trabalho nos bastidores do cinema, onde falsificamos realidades para vendêlas, ou torná-las mais palatáveis ao público, podem até beber ou se inspirar na arte, mas o que se produz é design, um produto industrial, ou se desejarmos, uma mercadoria, desenvolvida para ser consumida seguindo determinadas regras da sociedade industrial e das estruturas de um determinado modo de produção.

Segundo Forty, grande parte da literatura dos últimos cinquenta anos entenderia que o principal objetivo do design seria tornar os objetos belos, mais ou menos como os objetos de arte, contudo trata-se de uma noção que considera a dimensão estética como parte do projeto funcionalista. A beleza do objeto industrial é compreendida como algo para ser adicionado ao que é utilitário no produto, portanto a beleza é sempre funcional e não algo "transcendental" como acontece com a arte tradicional. Do mesmo modo, Forty afirma que poucos autores, seja de estudos sobre o design, seja de estudos sobre arte, associariam o lucro e a transmissão de ideias estéticas. Para ele, a estética e lucro são coisas que foram estudadas separadamente como sendo fenômenos independentes. A partir desta constatação, Forty pretende desenvolver em seu livro Objetos de Desejo, os aspectos econômicos e ideológicos do design.

$\mathrm{O}$ autor situa o nascimento do design num determinado estágio da história do capitalismo (meados do século XVIII) e enfatiza seu papel na criação da riqueza industrial, distanciando-o de sua conotação de "atividade artística" no sentido tradicional. Do mesmo modo, Forty menciona os dois sentidos do termo design na linguagem cotidiana: o primeiro refere-se à aparência das coisas (a 
dimensão estética) e o segundo "à preparação de instruções para a preparação de bens manufaturados" (a dimensão funcional), concluindo que os dois sentidos se complementam, já que a aparência estética dos objetos industriais é consequência das formas de produção.

Assim, arte e design precisam ser entendidas como coisas distintas e a busca do belo no design estaria, na maioria das vezes, condicionada em função do lucro e do estímulo ao desejo do consumo ou "desejo do objeto" O mesmo fenômeno ocorre no campo da arte, mas numa categoria bastante diferente, já que se refere a um nicho de mercado, a uma demanda de outra natureza - objetos validados mais por sua dimensão simbólica, isto é, pelo que significam socialmente (não entraremos nesta alçada). Sintetizando, o que determina um objeto de design são os grupos sociais e as indústrias que o produzem e suas relações com a sociedade que os vende e consome.

Isto posto, as condições históricas e sociais em que determinado objeto de design foi produzido são fundamentais para compreendê-lo: A história do design é a história das sociedades. O sucesso do capitalismo sempre dependeu da sua capacidade de "inovar" e de vender novos produtos.

A capacidade de mudar a aparência das coisas, mesmo sem mudar as coisas em si, é o grande trunfo do design e dos designers, que já não seguem mais a fórmula "a forma segue a função", mas, inevitavelmente, estão presos à função.

Hipoteticamente, no design a função estética guiaria a forma enquanto na arte a forma impõe-se sobre a função.

Os bens manufaturados variaram na aparência, devido não a imoralidade ou a intencionalidade de seus produtores, mas às circunstancias de sua produção e seu consumo. A fim de compreender o design, devemos reconhecer que seus poderes de disfarçar, e esconder e transformar foram essenciais para o progresso das sociedades industriais modernas. (FORTY, 1986, p.) 
Forty cita as porcelanas pseudo arqueológicas fabricadas por Wedgwood como uns dos primeiros designers bem-sucedidos e os motivos desse sucesso residiam (graças a sua parceria com Bentley) na racionalização dos métodos de produção, técnicas criativas de marketing e atenção aos produtos. O que aproxima, guardadas as devidas proporções, aos bons designers que produzem para o mercado cinematográfico, o criador precisa estar ancorado em uma equipe de arte, em um produtor, em um distribuidor, enfim, em figuras que dominem o mercado para viabilizar seu produto.

Da mesma forma que Wedgwood e Bentley não tencionavam fingir que seus produtos eram antiguidades genuínas, os designers do cinema também não pretendem que os vestidos e móveis que aparecem nas telas sejam vistos como originais verdadeiros saídos dos baús do tempo, mas que sejam visualmente tão ou mais convincentes que seus originais dentro da dramaturgia, isto é, eles precisam ser apenas verossímeis (ou de acordo com a proposta estética do filme).

O pulo do gato de Wedgwood/Bentley estava exatamente em perceber uma valorização simbólica (em sua época) das antiguidades clássicas em seus valores estéticos e morais e, consequentemente, dos produtos que a representavam. Enfim, a dupla de industriais intuiu que o valor simbólico das antiguidades poderia ser transformado em valor pecuniário e assim eles poderiam vender mais e auferir maiores lucros. Assim, eles começam a produzir objetos neoclássicos que seguiam apenas em aparência os originais encontrados em escavações arqueológicas em Pompéia e Herculano, mas que, devido ao método industrial de produção, tinham um custo acessível ao cidadão comum da classe média. A questão, portanto, seria fomentar o desejo de compra das pseudo antiguidades arqueológicas ao disponibilizar objetos industriais acessíveis e passíveis de suprir esse desejo.

Tudo exige uma compreensão por parte do designer (e do historiador que o avalia) do momento histórico e das circunstâncias sociais presentes para a inserção de um "novo" design para um objeto já existente ou para a criação de um objeto circunstancial ao momento. Sempre que se resgata um corpo ou objeto histórico (oriundo de uma época que não a presente) para recriá-lo, pode-se dizer que se criou um "novo corpo histórico" ao qual foram acrescentados a história presente e o olhar do criador ou pesquisador. A diferenciação dos produtos, e dos materiais utilizados para produzi-los são parte dessa engrenagem que inclui cena social e industrial, além da cena política. 
O domínio dos materiais disponíveis no mercado, dos custos de produção e de mão de obra são elementos que continuam sendo fundamentais para o produtor desde o início do capitalismo (Bourdieu, 2004,), só mudam as formas de lidar com essas informações no mundo "pós-globalização". Isso vale para qualquer produção industrial, incluindo o cinema e a televisão.

Assim, as classes mais altas consumiam os produtos mais sofisticados ou os originais, tal como as verdadeiras antiguidades arqueológicas do sul da Itália e de alto custo, enquanto isso, eram produzidos similares mais baratos e acessíveis às classes menos favorecidas que desejam os mesmos produtos e que simbolizavam status e eram largamente alardeados pela mídia, tal como nos dias de hoje.

Chega-se ao consenso capitalista que o mundo não mudou muito desde Wedgwood. Produtos fake - falsos - são fornecidos ao grande público com qualidade inferior, porém com design similar aos originais arqueológicos.

Outro aspecto do design que está presente no figurino e, na estética do cinema são as formas de utilização das cores e padronagens (listras, estampas etc.), seja em suas conotações sociais, classicistas, mercadológicas, psicológicas ou puramente plásticas.

Muitas vezes o que está estampado nos cenários e figurinos dos filmes de época, remonta da Idade Média, onde as listras eram usadas para distinguir, ou separar, classes e castas e as cores tinham toda uma simbologia. É necessário um conceito prévio ao se utilizar cores, listras ou até estampas em um figurino ou cenário que partam de um corpo histórico determinado. Essas mesmas listras atravessaram os tempos, porém mantiveram suas características de "marcar" excluídos como prostitutas, prisioneiros, loucos ou leprosos (PASTOUREAU, 1993, p.14).

No ocidente medieval são numerosos os indivíduos, reais ou imaginários, a quem a sociedade, a literatura ou a iconografia impõem vestes listradas. Todos esses são, por um ou outro motivo, excluídos ou rejeitados, desde o judeu e o herético até o bufão ou saltimbanco, passando não só pelo leproso, o carrasco ou a prostituta, mas também pelo cavaleiro traidor dos romances da Távola Redonda, pelo insensato do Livro dos Salmos ou pelo personagem de Judas. Todos perturbam ou pervertem a ordem estabelecida; todos temem maior ou menor grau, algo a ver com o Diabo. (PASTOUREAU, 1993, p.12)

No mundo moderno o design retomou a questão das listras mudando um pouco sua conotação original e enfatizando sua marca principalmente nos 
chamados dispositivos de poder tão bem estudados por Foucault nos presídios, por exemplo. Vejamos o caso das roupas listradas para os detentos. E sem ter abandonado a questão de classes, o uso sinalético das listras para presos foi estendido também para os demais subalternos, tais como mordomos e empregados domésticos. A noção foi sendo expandida e chegou a estabelecer sua simbologia para significar objetos de higiene, tais como pijamas e lençóis hospitalares, por exemplo. Do mesmo modo as listras mantêm sua origem heráldica nas bandeiras e nas armas, o que originou um viés lúdico nas roupas infantis e também nos uniformes esportivos. Da mesma forma que as listas distintivas, as cores também mudaram de conotação através do tempo. O que, mais uma vez, mostra como o design precisa ser compreendido em seu contexto temporal, histórico e sociológico.

$\mathrm{O}$ amarelo e o roxo, com toda sua carga de significação religiosa que possuem, nos anos sessenta e setenta ganham o significado de modernidade (mais ainda se estiverem juntos) e o vermelho da paixão, hoje pode ser compreendido como o vermelho da hemoptise do tísico (Moulin Rouge, Baz Luhrman), das feridas de cristo (Sigmata, Rupert WainWright) ou do sangue que alimenta os modernos canibais (Hanibal), lobisomens (Crepúsculo) e vampiros (Drácula de Copolla, Entrevista com o Vampiro) e outros, isso sem esquecer o farol vermelho que diz "frear" como resposta prática, instintiva e contemporânea (Bourdieu, 2004, p.270).

O que foi compreendido um dia apenas como um sinal para parar como o vermelho ou seguir como o verde, hoje têm tantos matizes emocionais, funcionais, afetivos, convencionais, históricos, enfim, que transcendem qualquer tentativa de enquadrá-los dentro do termo "design" ou "arte", ou "psicologia". Enfim, as palavras não são mais suficientes para denominar as coisas, num mundo em que não sabemos nem o que são as coisas, em que confundimos os objetos e os sujeitos, o individual e o coletivo, o consciente e o inconsciente, o subjetivo e o objetivo, o outro e nós mesmos. 


\subsection{A Costura do Cinema}

Tudo nos leva a crer que na história da humanidade, o homem sempre teve necessidade de reproduzir não só a sua realidade como também o movimento dela. As sombras chinesas, feitas com recortes de papel e os bichinhos de sombra feitos com as mãos e projetados em tamanho gigante em paredes ou lençóis são muito anteriores à luz elétrica e já eram precursores do que futuramente se chamaria cinema.

Uma descoberta feita por Ptolomeu no século II, chamada "persistência retiniana", somada às pesquisas do movimento e a descoberta da estroboscopia, levou vários inventores no século XIX a criar experimentos que seriam apelidados de tataravós do cinema, também conhecidos como brinquedos óticos.

Essas pesquisas e descobertas culminam com a invenção do cinematógrafo $($ do grego kinema $=$ movimento e grafos $=$ escrita $)$, criado pelos irmãos franceses Louis e Auguste Lumière.

O filme é um meio de comunicação multimidiatico. Apresenta-se como um mosaico composto por diversos elementos como a construção do ambiente, a iluminação e o enquadramento, os gestos e diálogos dos atores, o ritmo da montagem, som ambiente e trilha musical. Reúne assim formas de expressão múltiplas: imagem, movimento, ritmo, diálogos, sons e música, dramaturgia. Envolve noções de tempo e espaço: o tempo é dado pela montagem, o espaço é o locus da imagem. A matéria prima para a construção dessa imagem [...] é constituída a partir de uma série de signos visuais que concorrem para um projeto de linguagem visual, concebido e realizado coletivamente.

[...]. Essa elaboração apresenta características de um projeto complexo e multiautoral que envolve criação, construção de significados, veiculação de uma proposição ideológica e eventualmente comercial, adequação a condições objetivas como orçamento, recursos técnicos e disponibilidade de tempo, características essas que permitem incluí-lo na categoria de um projeto de Design. (BUNGARTEN, 2013, p.72)

O tempo é o elemento primordial e o responsável pela grande magia do cinema. Ele é a causa tanto do pioneirismo do cinema quanto da reprodução da realidade. 
Ao aprisionar o tempo real da imagem em movimento o cinema gerou tal semelhança com a realidade que passamos a acreditar na existência concreta dessa imagem. Pela primeira vez se reproduzia o tempo, esse mesmo tempo que no final do século XIX fez o público correr com medo do trem num dos filmes dos irmãos Lumière.

Mais de cento e vinte anos se passaram e nesses anos reproduzir tecnicamente o real em aparente movimento tornou-se algo banal, sendo a reprodutibilidade hoje é um dos pilares da sociedade contemporânea (Benjamin, 1985, p.165).

A imagem reproduzida em aparente movimento é, atualmente, uma forma familiar. Há uma simultaneidade entre o acontecimento e sua divulgação. A representação da dinâmica do tempo no cinema é contemporânea das novas noções de tempo e espaço.

Essa gradativa familiaridade com a imagem em movimento faz com que o espectador fique cada dia mais exigente e mais difícil de "enganar", tornando a credibilidade do cinema cada vez mais dependente da sua capacidade de "parecer de verdade". Essa corrida atrás da perfeição leva o cinema a uma recriação do real que transcende o original. O domínio da imagem acaba por criar um "falso mais verdadeiro que o real".

Quando entramos em um cinema e nos vemos diante de um espetáculo de imagens "perfeitas", ou iguaiszinhas à realidade, esquecemos que por trás destas imagens existe um verdadeiro trabalho de reconstrução do real, da realidade fílmica, que é muito mais uma convenção construída do que alguma coisa parecida com a realidade conseguida por intermédio de meios técnicos. A construção dessa realidade não está apenas nas mãos de iluminadores, diretores, sonoplastas, cenógrafos, figurinistas, uma grande equipe projetando e construindo essa ilusão. Enfim, existem uma infinidade de códigos visuais produzidos pela indústria cinematográfica e legitimados pelas instituições competentes que hoje pertencem à cultura de modo geral e em particular à cultura visual. Contudo, para que a mágica do cinema seja possível é necessário que o que está por trás transpareça, sem aparecer.

O que une uma equipe de produção de cinema é a criação de um universo visual, rítmico e sonoro especial, que ofereça ao espectador a vivência de uma narrativa. Instrumento essencial da composição do espetáculo, a direção de arte 
atua sobre um dos componentes centrais de construção da linguagem cinematográfica: seu aspecto visual.

Quando falamos em direção de arte, estamos referindo-nos a concepção do ambiente plástico de um filme, compreendendo que este é composto tanto pelas características formais do espaço e objetos quanto pela caracterização das figuras em cena. A partir do roteiro, o diretor de arte baliza as escolhas sobre a arquitetura e os demais elementos cênicos, delineando e orientando os trabalhos de cenografia, figurino, maquiagem e efeitos especiais. Colabora, assim, em conjunto com o diretor e o diretor de fotografia, na criação de atmosferas particulares a cada momento do filme e na impressão de significados visuais que extrapolam a narrativa. (HAMBURGER, 2014, p.18)

\subsection{Alinhavando a Trama: Cinema e Design}

Imagens têm sido meios de expressão da cultura humana desde as pinturas pré-históricas das cavernas, milênios antes do aparecimento do registro da palavra pela escritura. Todavia, enquanto a propagação da palavra humana começou a adquirir dimensões galácticas já no século XV de Gutemberg, a galáxia imagética teria de esperar até o século XX para se desenvolver. Hoje, na idade vídeo e infográfica, nossa vida cotidiana - desde a publicidade televisiva ao café da manhã até as últimas notícias no telejornal da meia noite - está permeada de mensagens visuais, de uma maneira tal que tem levado os apocalípticos da cultura ocidental a deplorar o declínio das mídias verbais. (Santaella e Noth, 1997, p.13)

O objetivo aqui é, tendo como referencial o trabalho de Bungarten, estabelecer uma interface entre os conceitos que engendram o processo da construção de significados na imagem cinematográfica e na área do Design como corpo de conhecimento.

Segundo Bungarten, o Design é essencialmente conceitual (simbólico?) e carrega consigo visões de mundo que dizem sobre o indivíduo e a sociedade.

A expansão das fronteiras do Design e suas bifurcações penetram, fundem ou conectam diversos campos do saber e do fazer estabelecendo, consequentemente, um vínculo com o Cinema.

Compreendendo o campo de ação do Design como o da configuração de objetos, podendo esses objetos serem produtos tridimensionais materiais, projetos 
gráficos impressos ou virtuais, produtos audiovisuais para qualquer mídia, projetos de design de serviço ou até "objetos imaginados", a construção de imagens cinematográficas e de seus significados segue os mesmos parâmetros fundamentais de outros objetos de Design.

Compreendendo o design da imagem cinematográfica como projeto de construção de uma linguagem visual, e considerando que este tem como resultado a produção de um objeto que conjuga aspectos objetivos e subjetivos, e que reúne um conjunto de significados com fins comunicacionais e simbólicos intencionalmente construídos, podemos considerar a hipótese da inserção deste projeto no conjunto de objetos possíveis do Design. (BUNGARTEN, 2013, p.69)
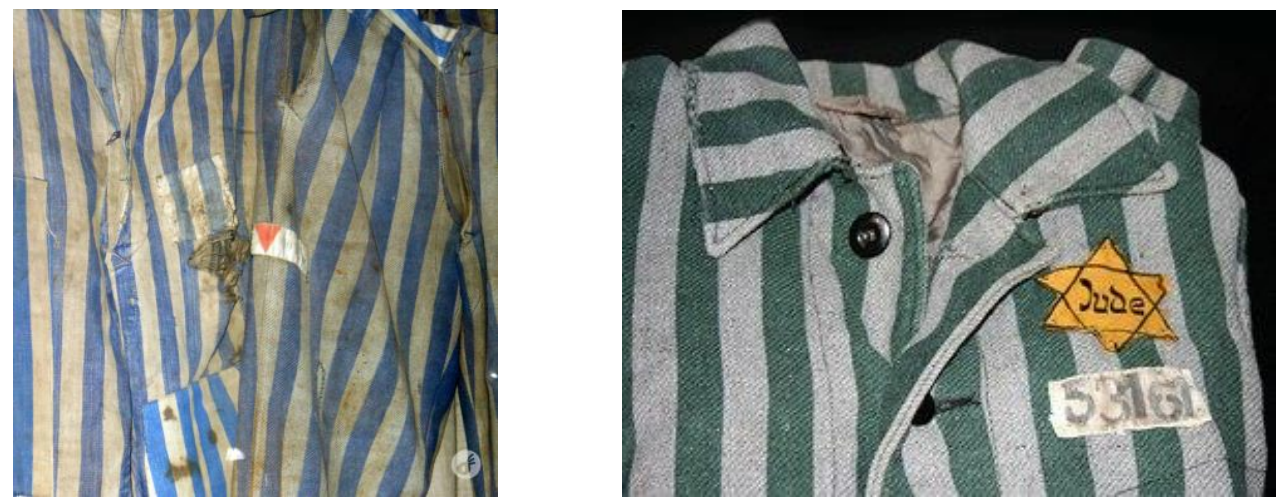

Figura 111 Uniformes de campos de concentração

A rede de lojas Zara recolhe camiseta que lembra uniforme de campo de concentração Peça infantil era listrada e com uma estrela de seis pontas. Empresa se desculpou e disse que a roupa foi inspirada em filmes clássicos de faroeste ${ }^{23}$

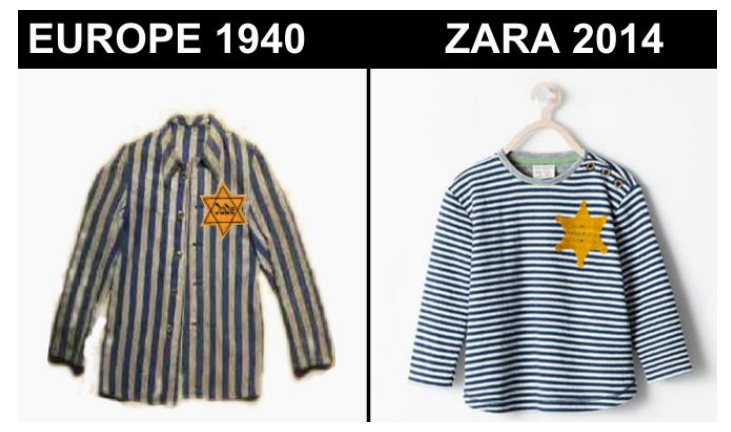

Figura 112 Matéria

http://msalx.veja.abril.com.br/2014/10/01/1313/alx_49629385d_original.jpeg?1409153996 


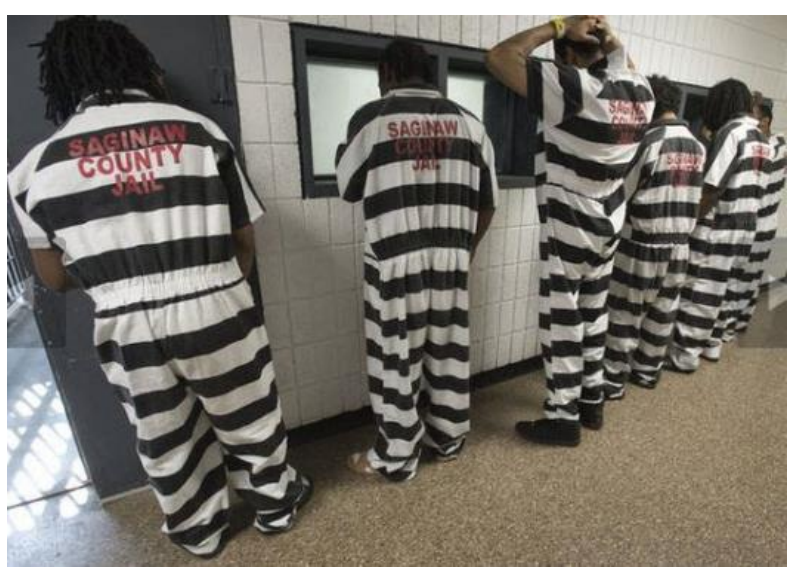

Figura 113 Presidiários de Saginaw

O sucesso do seriado "Orange is The New Black" incomodou o xerife William Federspiel, do condado de Saginaw. A cor laranja, que estampava os uniformes das prisões americanas, foi mudada para o clássico "listradinho". Segundo informações, o presídio do condado de Saginaw passou a adotar macacões com listras em branco e preto porque a série da Netflix tornou a cor "descolada demais", segundo o xerife local em entrevista ao MLive. O real motivo dessa mudança é que, dada a repercussão do seriado, o uso de roupas na cor laranja aumentou, o que dificulta o reconhecimento dos presos em eventuais fugas ou confusões, porque os internos têm costume de sair do cárcere para realizar trabalhos comunitários. O xerife também salientou que o uniforme da cadeia é cíclico e pode sofrer outra alteração ${ }^{24}$.

\footnotetext{
${ }^{24} \mathrm{http}: / /$ garotacotidiana.com.br/2014/07/30/por-causa-do-netflix-prisao-muda-uniforme/
} 


\section{5}

\section{CONSIDERAÇÕES FINAIS}

Nosso objetivo nesse trabalho não foi fazer ou responder perguntas e sim expor e disponibilizar informações que possam preencher lacunas, responder ou suscitar perguntas do leitor; seja ele profissional, estudioso de cinema ou leigo, curioso de dados difíceis de se encontrar sobre o figurino de época no Brasil.

Discorrer sobre um elemento plástico (principalmente um elemento que se constrói tridimensionalmente para ser aplicado em um suporte bidimensional que pretende dar a ilusão de tridimensionalidade - no caso o filme) como o figurino de cinema, que possui volume, movimento e precisa ser visto dentro do filme, é uma tarefa complexa e excitante para uma figurinista.

É excitante falar sobre o que fazemos, mas há que ter-se cuidado pois nosso trabalho é apenas uma peça em meio a uma enorme engrenagem chamada cinema. Sabemos que o filme é como um vitral e que cada peça que o compõe é fundamental para o todo, porém ao analisarmos a peça, o todo tem que estar sempre presente na nossa referência ou a peça não encaixará. 


\section{6}

\section{Ficha técnica dos filmes analisados}

\section{O QUATRILHO}

Título original O Quatrilho (Original)

Ano de produção 1995

Estreia 20 de Outubro de 1995 ( Mundial )

Duração 92 minutos

Países de Origem Brasil

Sinopse

Rio Grande do Sul, 1910. Em uma comunidade rural composta por imigrantes italianos, dois casais muito amigos se unem para poder sobreviver e decidem morar na mesma casa. Mas o tempo faz com que a esposa (Patricia Pillar) de um (Alexandre Paternost) se interesse pelo marido (Bruno Campos) da outra (Glória Pires), sendo correspondida. Após algum tempo, os dois amantes decidem fugir e recomeçar outra vida, deixando para trás seus parceiros, que viverão uma experiência dramática e constrangedora, mas nem por isto desprovida de romance.

Direção: Fábio Barreto

Roteiro: Leopoldo Serran,

Adaptação: Antonio Calmon,

Produção: Lucy Barreto, Luiz Carlos Barreto

Direção de produção: Gisele Hiltl,

Produção executiva: Luiz Carlos Barreto e Lucy Barreto

Produtor associado: Roberto Carneiro, 
Assistência de produção Janaína: Miotti,

Assistência de direção: Ricardo Favilla,; Marcelo Santiago,

Continuidade: Gisella Bezerra de Mello

Still Estevam Avellar

Coreografia: Sigrid Nora,

Direção de fotografia: Felix Monti,

Operador de camera: Gilberto Otero,

Trucagens: Animation

Fotografia da $2^{\mathrm{a}}$. unidade:, Luiz Antônio de Oliveira

Chefe eletricista: Carlos Alberto Ribeiro,

Eletricista: , Olívio Lima Filho; Ronaldo Lopes,

Maquinista: Antônio de;Almeida, José Luiz dos Santos,

Auxiliar de maquinista: Waldir Monteiro,

Engenharia de som: Roberto Carvalho,; José Nogueira,

Som direto: Cristiano Maciel,

Mixagem: , Mário Jorge Ferro; Jaques Morelenbaun,

Trilha sonora: Jaques Morelenbaun,

Ruídos de sala: Alexandre Jardim,; Pedro Jardim,; José Luiz Rosa,

Operador de microfone: Aloysio Compasso,

Montagem: Mair Tavares, e Karem Harley

Montagem de som: Virgínia Flores,

Direção de arte: Paulo Flaksman

Assistência de direção de arte: Ana Aschlee, 
Figurinos: Isabel Paranhos,

Cenografia: Sérgio Silveira,

Assistência de cenografia Leonardo: Maineri,; Rodrigo Soprana,

Carpinteiro: João Neri,

Contra-regra/acessórios de cenografia: Delanir Cerqueira,

Maquiagem: , Guilherme Pereira;

Costureira: Lourdes;Bastiani, Diva;Leidens, Nilda Ferreira, Marilse de Moura,;

Claudete de Almeida,

Penteados: Maria Conceição Santos,

Música-tema: Caetano Veloso,

Companhia(s) produtora(s): Filmes do Equador Ltda.; Produções

Cinematográficas LC Barreto Ltda.; Filmes do Equador Ltda.

Companhia(s) distribuidora(s): Consórcio Severiano Ribeiro \& Marcondes

\section{CARLOTA JOAQUINA A PRINCESA DO BRASIL}

Título original: Carlota Joaquina, a princesa do Brasil

Duração: 1h40min

Estreia: 1995

Sinopse

O filme retrata de modo satírico e cômico a história de Carlota Joaquina, a princesa do Brasil.

Aborda desde sua saída da Espanha em 1785 como a prometida ao infante real português João, até sua trágica morte em Portugal, em 1830, ilustrando diversos fatos históricos da época do Brasil Colônia. 
Ficha técnica do filme

Estúdio: Elimar Produções Artísticas

Distribuidora: Elimar Produções

Direção: Carla Camurati

Roteiro: Carla Camurati e Melanie Dimantas

Produção: Bianca de Felippes e Carla Camurati

Música: André Abujamra e Armando Souza

Direção de Fotografia: Breno Silveira

Direção de arte: Tadeu Burgos e Emília Duncan

Figurinos: Tadeu Burgos, Marcelo Pires e Emília Duncan

Edição: Cézar Migliorin e Marta Luz

\section{GUERRA DE CANUDOS}

Título Guerra de Canudos (Original)

Ano produção 1997

Estreia 3 de Outubro de 1997 ( Brasil )

Duração 170 minutos

País de Origem Brasil

Sinopse

A trajetória de uma família que se vê envolvida com os seguidores de Antônio Conselheiro e desenvolve opiniões conflitantes sobre o líder do movimento de Canudos. Com direção de Sérgio Rezende (Mauá - O Imperador e o Rei) e José Wilker, Paulo Betti, Cláudia Abreu, Marieta Severo e Selton Mello no elenco.

Direção Sergio Rezende 
produção Mariza Leão ..

co-produção José Wilker ...

... produção executiva Mariza Figueiredo

Música Edu Lobo

Direção de FotografiaAntonio Luiz Mendes

Montagem Isabelle Rathery

Direção de Arte Claudio Amaral Peixoto

Assistência de Direção de Arte Henrique Murthe

Figurinos Beth Filipecki

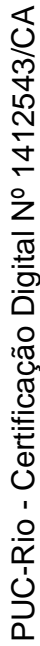

Supervisão de pós-produção Cecília Amado

Gerência de produção César Cavalcanti da Segunda Diretor

Primeiro Assistente de Direção Ricardo Pinto e Silva

assistente do diretor Jurandir de Oliveira ...

edição de diálogo Ana Chiarini ...

edição de diálogo Marlena Grzaslewicz ...

mixagem de foley George A. Lara ...

edição de som Luiz Adelmo Manzano (como Luiz Adelmo)

. efeitos de som editor Jacob Ribicoff

supervisão de edição de som Ira Spiegel ...

som Mark A. Van Der Willigen ... Efeitos Especiais de

efeitos especiais Federico Farfán operador de câmara Giselle Chamma ...

direção de fotografia: segunda unidade Mauro Pinheiro Jr. ...

assistência de câmara Joaquim Torres ... 
coordenaçãa de pó produção Paul Leonardo Jr. ...

. supervisão de roteiro Cecília Amado 
Referências bibliográficas

AGAMBEN,Giorgio. O que é o contemporâneo e outros ensaios, Sta Catarina:Argos, 2009

AUMONT, Jacques. A imagem, Campinas, SP: Papirus, 1983

AUMONT, Jacques. O olho interminável - cinema e pintura, São Paulo:

Cosac Naify, 2004

BENJAMIN, Walter. Magia e técnica, arte e política, São Paulo: Brasiliense, 1985

BOURDIEU, Pierre. A economia das trocas simbólicas, São Paulo: Perspectiva, 2004

BOURDIEU, Pierre. O poder simbólico, Rio de Janeiro: Bertrand Brasil,2002

BOVAY, George-Michel. Cinéma; un oeil ouvert sur le monde. Lausanne: edition

Clairefontaine, 1952

BUNGARTEN, Vera. A imagem cinematográfica, convergências entre design e cinema. Tese de doutorado, PUC - Rio de Janeiro, 2013

CARNES, Mark C. (org) Passado imperfeito; a história no cinema. Rio de janeiro: Edit.Afiliada, 1997

COPPOLLA, Francis Ford. Coppola and Eiko on Dracula. São Francisco: Collins Publishers, 1992

COUTO, Rita Maria de Souza. Design como corpo de conhecimento. Rio de Janeiro: PUC

DURAND, José Carlos. Moda, luxo e economia. São Paulo: Edit. Babel Cultural, 1988

ETTEGUI, Peter. Production Design \& Art Direction, screencraft. Londres: Roto Vision, 1999

FARINA, Modesto. Psicodinâmica das cores em comunicação. São Paulo: Editora Edgard Blucher Ltda, 1986 
FLUSSER, Vilém. O mundo codificado: por uma filosofia do design e da comunicação. São Paulo: Editora Cosac naify, 2007

FORTY, Adrian. Objeto de desejo - design e sociedade desde 1750.

São Paulo: Cosac Naify, 2007

HAMBURGER, Vera. Arte em cena: a direção de arte no cinema brasileiro. São Paulo: Editora Senac, 2014

LANGLOIS, Henri. Musée du cinema. Paris; editions Cinémathèque Française, 1984

MORIN, Edgar. O cinema ou o homem imaginário: ensaio de antropologia sociológica, São Paulo: E Realizações, 2014

MUNIZ, Rosane. Vestindo os nus - 0 figurino em cena. Rio de Janeiro:

Editora Senac Rio, 2004

PASTOUREAU, Michel. O Pano do Diabo - Uma história das listras e dos tecidos listrados. Rio de Janeiro: Jorge Zahar Editor,1993

PEDROSA, Israel. Da cor a cor inexistente. Rio de Janeiro: Léo Christiano Editorial, 1977

PEIXOTO, Jefferson Ribeiro, A Indumentéria de Época e a Arte de Luiz Carlos Ripper, dissertação de mestrado, UNIRIO, Rio de Janeiro. 2015 POZENATO, José Clemente, O Quatrilho, Porto Alegres: Mercado Aberto, 1995

RAINHO, Maria do Carmo Teixeira. A cidade e a moda. Brasília: Editora Universidade de Brasília, 2002

RAMOS, Fernão; MIRANDA, Luiz (org.). Enciclopédia do Cinema Brasileiro. São Paulo: Editora Senac, 2000.

RANCIÈRE, Jacques. A fábula cinematográfica. Campinas, SP: Papirus, 2013

REZENDE, Nilza, Guerra de Canudos: o filme. São Paulo: Editora Senac, 1997

SALLES GOMES, P.E. Humberto Mauro, Cataguases, Cinearte. São Paulo: Perspetiva , 1974

SANTAELLA, L.; NOTH, W. Imagem, cognição, semiótica, mídia. São Paulo: Editora lluminuras Ltda, 1998

SISSON, Rachel. Cenografia e vida em fogo morto. Rio d janeiro: Editora Artenova, 1977 
SORLIN, Pierre. Sociologie du cinema. Paris: édition Aubier Montaigne, 1977

TARKOVSKI, Andrei. Esculpir o tempo. São Paulo: Martins Fontes, 1990 XAVIER, Ismail (org.) A experiência do cinema. Rio de janeiro: edições Graal, 1983

ZATTERA, Vera Stedile. Traje típico gaúcho. Porto Alegre:Lusográfica. Gráfica e Editora, 1989

ZATTERA, Vera Stedile. Trajes do imigrante italiano do Rio Grande do Sul; Italia - Brasil, 1850 - 1990. Porto Alegre:Pallotti, 1991 